\title{
UNIVERSITY TEACHERS’ PERCEPTIONS AND EVALUATIONS \\ OF ETHICS INSTRUCTION IN PUBLIC RELATIONS CURRICULUM
}

by

ELINA ERZIKOVA

\begin{abstract}
A DISSERTATION
Submitted in partial fulfillment of the requirements for the degree of Doctor of Philosophy in the College of Communication in the Graduate School of The University of Alabama
\end{abstract}

TUSCALOOSA, ALABAMA 
Copyright Elina Erzikova 2009

ALL RIGHTS RESERVED 


\begin{abstract}
This study examined the present state of teaching ethics in university public relations departments in the U.S. and abroad. The results indicated that public relations teachers perceived ethics instruction in public relations education to be essential, and they believed in a close tie between general morality and professional ethics. However, as the results of a quantitative survey suggested, foreign participants believed that ethics instruction helps students make right choices on the job less so than did participants who were born and teach in the U.S. A series of qualitative interviews with communication teachers in Western European universities revealed that the foreign teachers did not perceive themselves as direct contributors to the public relations industry. Instead, they saw themselves as individuals who are responsible for general liberal education of the youth, not specialized training.

Multiple regression analysis of a number of respondents' demographics showed that the higher the participants' rank, the less favorable attitude they held toward the value of ethics education to students. This result is a subject of a future investigation.

The majority of participants recognized ethics instruction incorporated in courses throughout the PR curriculum as the most valuable format of ethics instruction delivery. The most used pedagogies - teacher lectures, case studies, and group discussion — appeared to be the most effective approaches, whereas the most used resources in teaching ethics - textbooks, trade magazine articles, and newspaper or magazine stories - were perceived as the most effective material in teaching ethics.
\end{abstract}


Future research should focus on the content of ethics courses; theoretical systems (e.g., Judeo-Christian ethics, Kantian deontology, utilitarianism, and others) examined in the course; whether and to what extent ethics is not only a teaching, but also a research interest of public relations teachers; and, the most important, whether and to what extent ethics instruction affects public relations graduates' future as individuals and professionals.

This study makes a pedagogical and theoretical contribution to a thin literature on ethics education. Research based on examination of teachers' perceptions and preferences may help public relations educators see trends in contemporary education, better understand their underpinnings, and possibly enhance their own teaching and educational curricula. 


\section{DEDICATION}

This dissertation is dedicated to Tom and Regina Wright, the Decatur Daily, AL. 


\section{LIST OF ABBREVIATIONS AND SYMBOLS}

$\begin{array}{ll}\text { ANOVA } & \text { Cronbach's index of internal consistency } \\ d f & \text { Analysis of variance } \\ & \text { Degrees of freedom: number of values free to vary after certain restrictions have } \\ F & \text { Fisher's } F \text { ratio: A ratio of two variances } \\ M & \text { Mean: the sum of a set of measurements divided by the number of measurements } \\ & \text { in the test } \\ & \text { Number } \\ p & \text { Probability that a value occurs when testing the null hypothesis } \\ r & \text { Pearson product-moment correlation } \\ \text { SD } & \text { Standard deviation } \\ \text { SPSS } & \text { Statistical Package for the Social Sciences } \\ & \text { Computed value of a } t \text { test }\end{array}$




\section{ACKNOWLEDGEMENTS}

If you are reading this page, it means that you are my relative, mentor, faculty member, colleague, friend or classmate. Whoever you are, I appreciate your endorsement and encouragement that resulted in this moment: Writing acknowledgements.

If I start mentioning everyone whom I owe my gratitude, the length of the Acknowledgements might exceed the number of pages of dissertation. And even after that, I would still have a fear that I forgot to mention someone who helped me to get through not only the process of crafting this manuscript, but also the exciting and adrenaline-driven process of the graduate study.

Thank you for your time, expertise, support, advice, energy, interest, tolerance, kindness, care, patience, faith, inspiration, friendship and love. The tide always rolls!

I am also thankful to a grant giver, the Arthur Page Center (Penn State university), for their financial support of this dissertation. 


\section{CONTENTS}

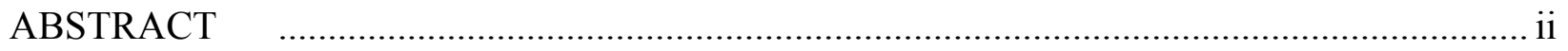

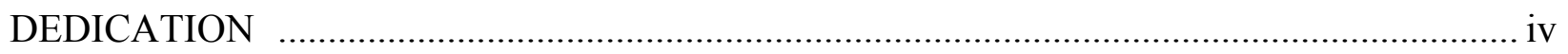

LIST OF ABBREVIATIONS AND SYMBOLS ......................................................

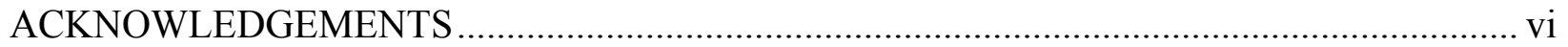

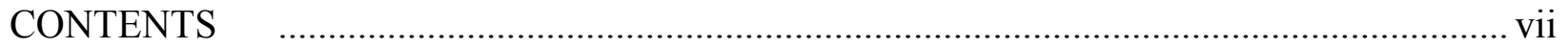

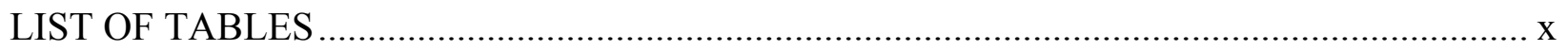

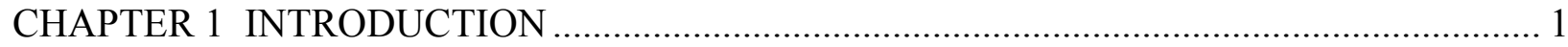

CHAPTER 2 LITERATURE REVIEW AND RESEARCH QUESTIONS ............................ 4

2.1. Ethics Scholarship and Public Relations.................................................................. 5

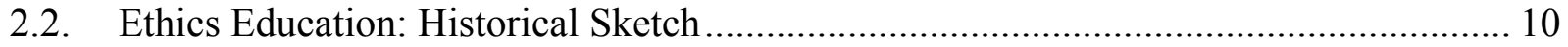

2.3. Modern Thoughts about Teaching Ethics ...................................................... 13

2.4. Commission on Public Relations Education about Ethics Education .......................... 17

2.5. Goals of Teaching Ethics and Value to Students of Ethics Education......................... 19

2.6. Ethics Education in University Curricula........................................................... 22

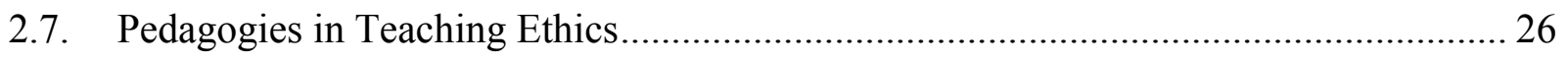

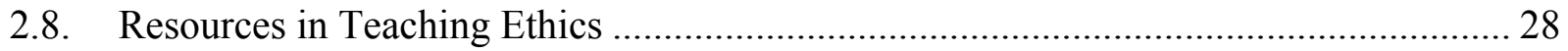

2.9. Techniques for Evaluation of Student Learning ................................................... 30

2.10. American and European Universities and Globalization ........................................ 34

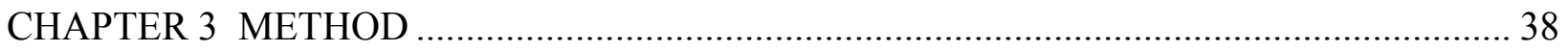

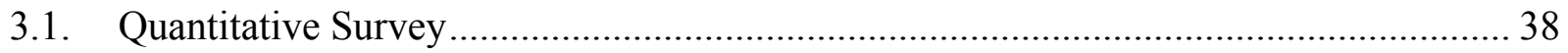

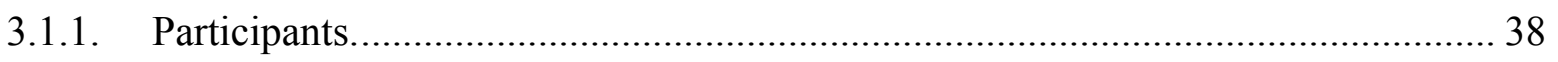

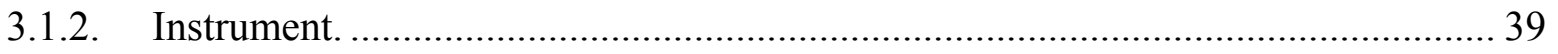

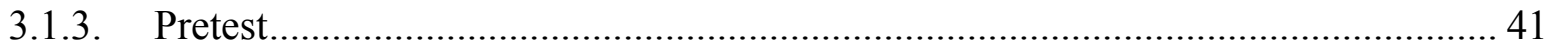

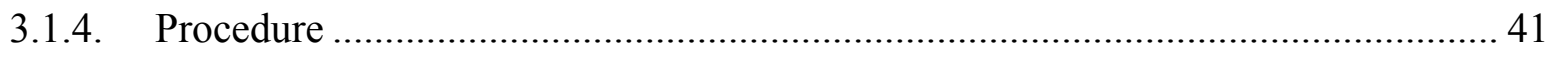

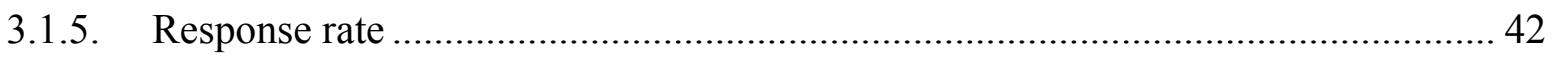


3.2. Interviews with U.S. and European teachers................................................................ 43

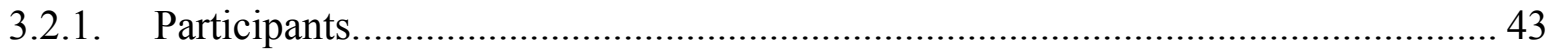

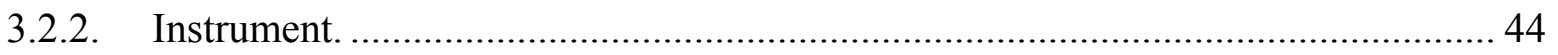

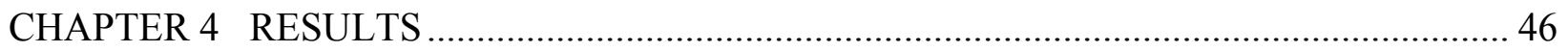

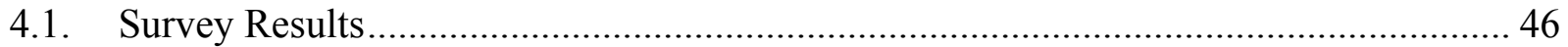

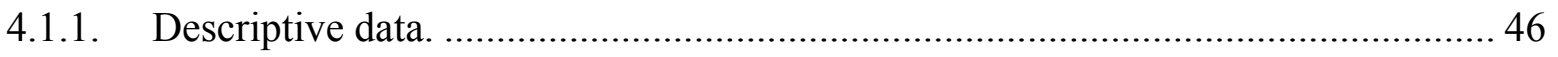

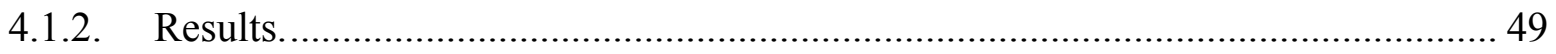

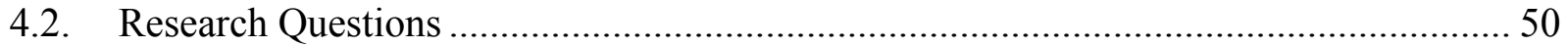

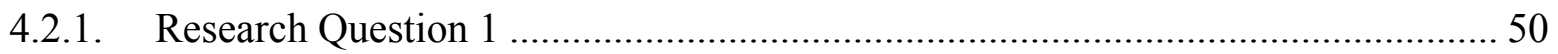

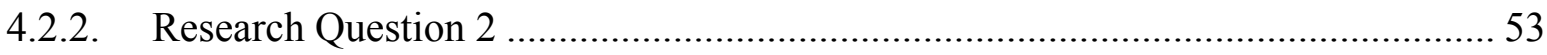

4.2.3. Research Question 3 …………………….................................................. 58

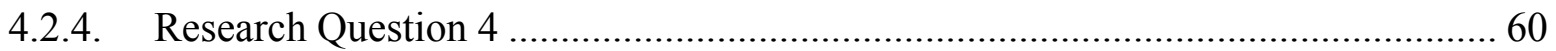

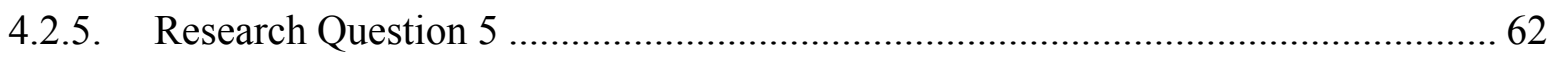

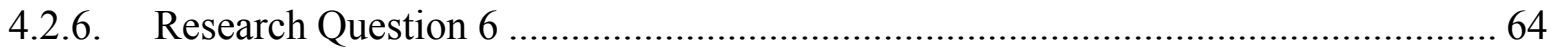

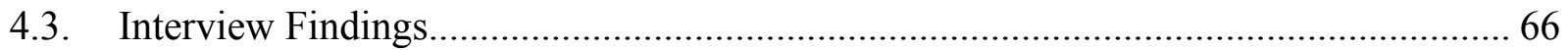

4.3.1. Proposition I. American and European public relations educators think that ethics are important for education, but they view this importance in different ways....... 66

4.3.1.1. Awareness as preparedness to deal with ethical dilemmas................................ 66

4.3.1.2. Awareness as the responsibility to use knowledge in the ethical way............... 67

4.3.1.3. Awareness as an induction into the profession................................................ 67

4.3.2. Proposition II. American and European public relations educators' practices reflect

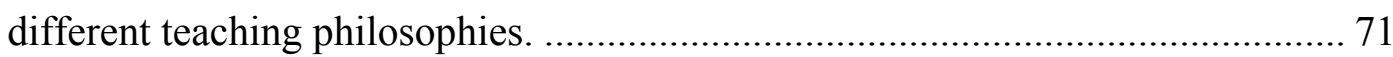

4.3.3. Proposition III. European participants think that there are apparent differences in ethics education in the U.S. and Europe.............................................................. 75

4.3.4. Proposition IV: American and European educators appear to be similar in their perceptions of challenges in teaching ethics. .................................................... 79

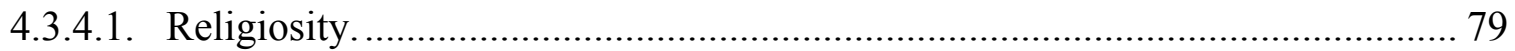

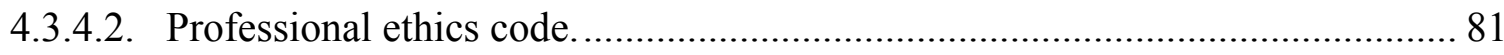

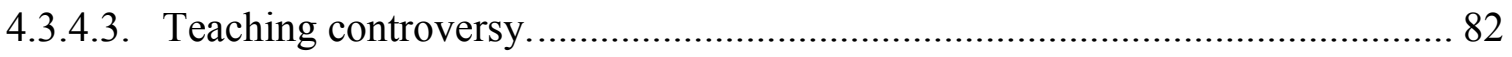

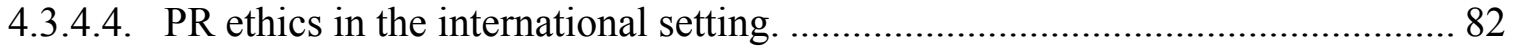

4.3.4.5. Problem of evaluation of student learning..................................................... 84 
4.3.4.6. Journalism vs. Public Relations, or Who is responsible for a bad PR image? .. 85

4.3.4.7. Quit or comply? 87

4.3.5. Proposition V: Participants believe that the best method to teach ethics is to

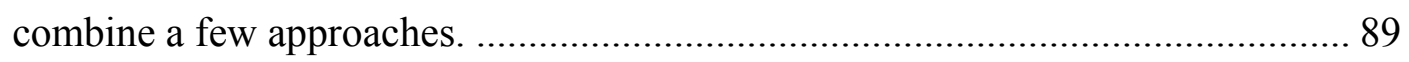

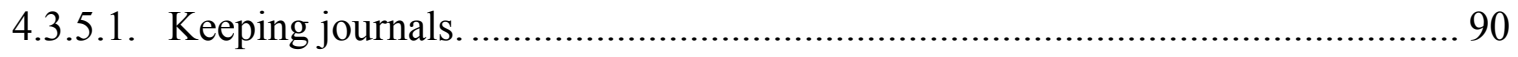

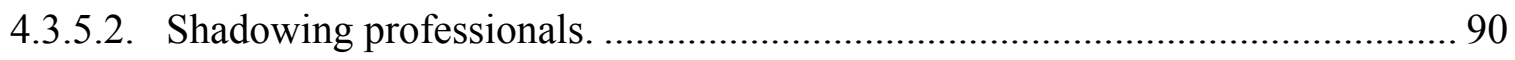

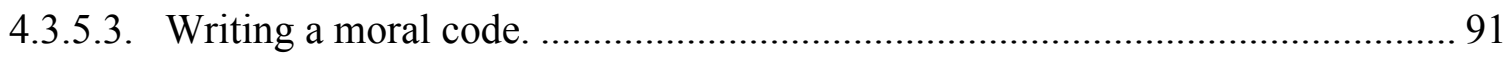

4.3.6. Proposition VI: The majority of American and European educators think that the best format of ethics instruction delivery is to combine a free-standing course with ethics discussions in every course ............................................................ 92

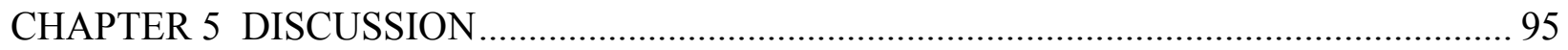

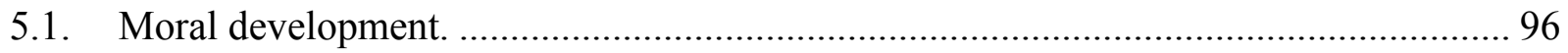

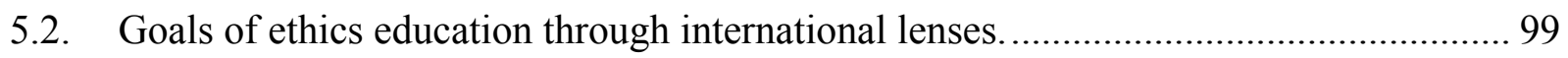

5.3. Attitudes toward format of ethics delivery...................................................... 101

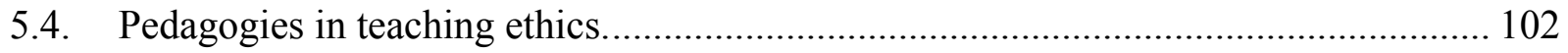

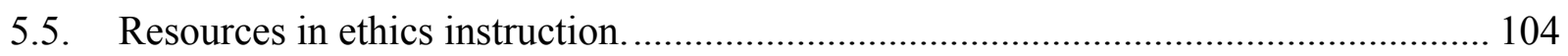

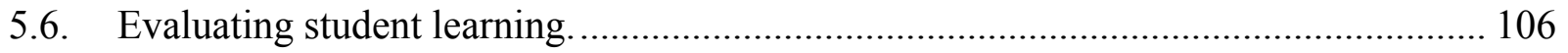

5.7. Similarities and differences in teaching philosophies and practices of American and

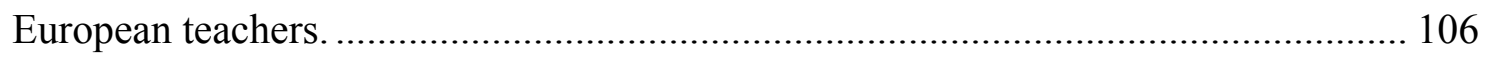

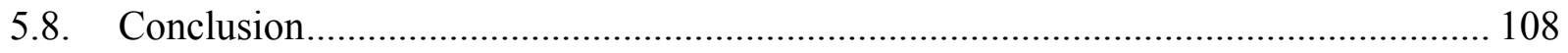

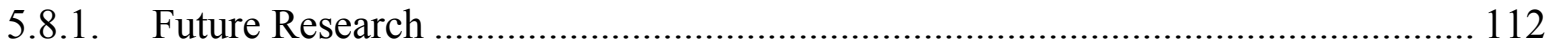

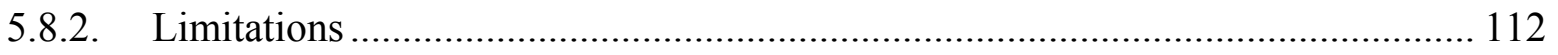

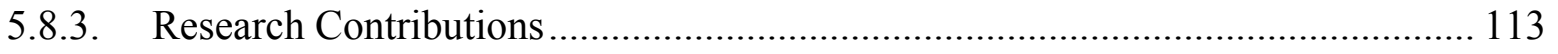

REFERENCES 114

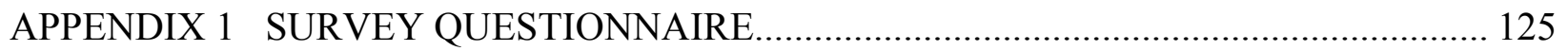

APPENDIX II ELECTRONIC INVITATION TO PARTICIPATE IN SURVEY ................. 132

APPENDIX III PARTICIPANT INFORMED CONSENT FORM .................................... 134

APPENDIX IV INTERVIEW GUIDE WITH AMERICAN AND EUROPEAN PUBLIC

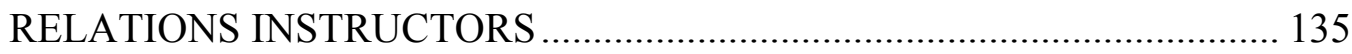




\section{LIST OF TABLES}

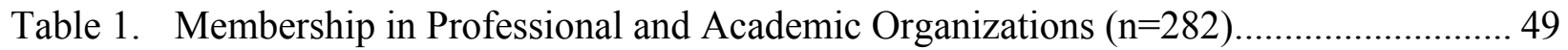

Table 2. Participants' ( $\mathrm{n}=282)$ Evaluations of the Primary Goals of Ethics Education............ 51

Table 3. ANOVA-test Comparison among Participants who Were Born and Teach in the U.S. ( $\mathrm{n}=186)$, Who Were Born Abroad and Teach in the U.S. $(n=23)$, and Participants Who Were Born and Teach Abroad $(n=35)$..................................... 53

Table 4. Means and Factor Analysis for Value to Students of Ethics Education Scale Items ... 56

Table 5. Multiple Regression Analysis Results for "Value to Students of Ethics Education"

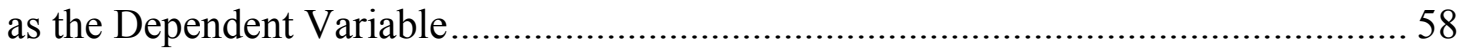

Table 6. The Value of Formats of Ethics Instruction Delivery $(n=265)$............................... 59

Table 7. Usage and Effectiveness of Pedagogies in Teaching Ethics .................................. 61

Table 8. Usage and Effectiveness of Resources in Teaching Ethics ..................................... 63

Table 9. Usage and Effectiveness of Assessment Tools in Teaching Ethics ......................... 65 


\section{CHAPTER 1}

\section{INTRODUCTION}

This research focuses on ethics education in university public relations departments in the U.S. and Western Europe. Ethical decisions and actions are important in our personal and professional lives. This is certainly true in the public relations profession, where ethical misconduct continues to make attractive headlines for journalists. Meanwhile, Bowen (2008) argued that normatively, the public relations management function is noble because it intends to create understanding and promote dialogue and collaboration rather than to manipulate and deceive. The ethical and the moral are considered essential components of a theory of excellence and effectiveness in PR (Grunig, 1992). In Bowen's (2007a) words, "Ethics is a single excellence factor and the common underpinning of all (Italic is original) factors that predict excellent public relations" (p. 275).

Higher education is presumably one of the ways that leads future PR practitioners to the role of a moral agent by making them aware of ethical choices and preparing them to resolve ethical dilemmas. In Wright and Turk's (2007) words, “[S]pecialized educational preparation-education that provides the technical and managerial knowledge skills needed in a particular profession-clearly is a hallmark of professionalism (p. 576). In this light, Kruckeberg (1998) argued that PR as a professional occupation required professional 
education, whereas Grunig and Grunig (1991) said that academic preparation of PR practitioners is one of the characteristics of excellent PR departments.

The purpose of this study is to examine the present state of teaching ethics in university public relations departments in the United States and abroad, predominantly in Western Europe. This study focuses, first, on how ethics is taught, what kind of pedagogies and assessment tools for evaluating ethics learning are considered the most effective, and what kind of teaching resources are employed by PR instructors. Second, the study examines instructors' perceptions of the goal of teaching ethics to PR majors and its value to students.

Although a number of studies in various academic disciplines have examined the process and underpinnings of teaching ethics, not many studies have elaborated this topic in the public relations field (Bowen, 2005). Therefore, through the investigation of teachers' philosophies and practices of teaching ethics, the present research will contribute to a thin literature on PR ethics education. Anecdotal data showed that in general, public relations instructors are attuned to innovative approaches in teaching public relations. It is hoped that the present research will yield results that PR instructors will find helpful in enriching their classroom experiences.

Attitudes and perceptions of instructors who teach courses in public relations at the university level are important because the American educational experience provides a model for teaching public relations elsewhere in the world. The PR profession was born in the Western hemisphere, and, even though the American dominance is fading these days (McKie $\&$ Munshi, 2007), the countries with a developing stage of public relations still look to the United States for guidance in research and teaching (Azarova, 2003). By the same token, Kruckeberg (1998), speculating about tasks of the Commission on Public Relations 
Education, argued that educational institutions throughout the world might find value in the Commission's recommendations and even voluntarily comply with them.

The Commission on Public Relations Education (2006) called for a standard practice importing or significantly adapting the U.S. and Western European models of PR education in Latin America and Asia. Therefore, assessing the contemporary state of ethics education in the U.S., one can speculate not only about the future of the profession in the West, but also about evolving trends in public relations education elsewhere in the world.

Despite Aristotle's contention that ethical behavior cannot be taught, but must be a part of a person's upbringing, moral philosophy was studied at the medieval university (Sloan, 1980). These days, ethics education is not taken as a panacea for the moral problems because awareness of ethical conduct does not necessarily result in moral behavior. Nevertheless, to leave ethics out of a curriculum might mean the failure to prepare students for real life — personal and professional—filled with moral quandaries. Although the effectiveness of ethics education has not been supported, "The experiment is worth trying, for the goal has never been more important to the quality of the society in which we live" (Bok, 1976, p. 30). Modern life is saturated with moral anxiety, and the pressure for moral education increases with the intensity of moral confusion in society (Radest, 1989). Lee (1990) argued that in public administration, failure to institutionalize ethics into the curriculum resulted in scarcity of teaching resources and uncertainty about the goals of teaching ethics and methods. The same might be true about other academic disciplines. 


\section{CHAPTER 2}

\section{LITERATURE REVIEW AND RESEARCH QUESTIONS}

This section is organized as follows: First, the literature on ethics scholarship and public relations is examined. Then, the history of ethics education in the U.S. is discussed. The third section of the literature review focuses on modern thoughts about ethics education. The fourth section addresses concerns about the public relations curriculum articulated by the Commission on Public Relations Education's (2006) report. The scholarship on main goals in teaching ethics is presented in section 5. Then, ethics education in the university curriculum is discussed (section 6). The final three sections of the literature review address issues of pedagogies, resources, and evaluation in ethics instruction.

To be consistent with previous research (Commission on Public Relations Education, 2006), this study adopted the operational definition used in the earlier project. Particularly, "ethics for the public relations profession" was defined as "a set of a priori (italic in original) principles, beliefs and values that should be followed by all who engage in public relations practice" (p. 21). As for the difference between the two notions, "morality" and "ethics," the former refers to actual moral choices and conduct, whereas the latter refers to the activities that reflect on, justify or criticize such choices and conduct (Camenisch, 1986). 


\subsection{Ethics Scholarship and Public Relations}

This section outlines the history of ethics scholarship in public relations, discusses the underpinnings of the two dimensions - normative and practical — in public relations, and reviews frameworks developed by PR scholars to analyze ethical dilemmas.

Public relations is a very young profession, compared, for example, to medicine that claims to have a 2500-year-old history (Lord \& Bjerregaard, 2003). Ideally, there might be a direct relationship between the "age" of a profession and the strength of its values and principles. It might be further argued that the firmness of professional standards increase not only through experience, but through a constant and scrupulous assessment of developmental stages. In this regard, Pratt (1991) noted that in 1988, PRSA identified only 16 articles and two books that dealt largely with public relations ethics. The author argued that two studies - Ryan and Martinson (1984) and Wright (1985) — evoked some interest in the subject. The former found that when behavioral guidelines were absent, public relations practitioners employed subjectivism as the moral-ethical theory; the latter indicated moderate to high levels of ethics among professionals in regard to moral and legal aspects of public relations practice.

The first issue of a U.S. academic journal devoted to public relations ethics was the summer 1989 issue of Public Relations Review. Analyzing a number of empirical studies, Pratt (1991) came to the conclusion that (1) public relations practitioners did not value ethics as an important issue; (2) public relations professionals cannot ignore the public's low evaluation of their professional ethics; and (3) older practitioners, possessing a higher degree of ethics, can help institutionalize ethics in the workplace. Pratt argued that the success of organizations in integrating ethical standards in their practices heavily depended on public 
relations professionals, whose activities publics would most likely associate with organizational behavior.

In this regard, professional ethics constitutes an occupational or role morality (Wueste, 1994). While ethics "plain and simple" applies to general human conduct, professional ethics is more narrow in its scope and institutional. This means that a "professional ethic/role morality is instituted, set up, established, by human action" (Wueste, 1994, p. 20). This fact, according to Wueste, explains why professionals might be obligated to act wrongly and be justified for the deeds that would be denounced by ethics plain and simple, or non-institutional morality.

It might be argued that a decline in American public relations supremacy in the global scope is explained by not so much a weakness of the contemporary American PR practice, but rather a rapid development of national PR fields. Metaphorically speaking, ambitious pupils declare their independence from the teacher and question his or her authority, while pursuing the goal of self-establishment. However, ties between the teacher and his or her students usually survive a rebellious period of the pupils' self-assessment —if they possess such a quality as appreciativeness. In other words, during upcoming years, public relations students throughout the world will study the Grunigian paradigm of excellence as a starting point of PR knowledge, while gaining understanding of their native public relations environments and searching for their own theories. And, unfortunately, they may sometimes "spin" information if a quick triumph is needed. The two dimensions - normative and practical — will continue to exist, and an unspoken competition between them might not ever be resolved. 
The public relations profession like numerous other occupations experiences a discrepancy between intentions and results. While normative theories call for social responsibility and moral behavior, real life provides examples of an "ethical misconduct disaster," or a situation in which ethics and law violations result in lawsuits and criminal charges that not only interrupt routine operations and diminish organizational reputation, but also literally destroy organizations (Chandler, 2007).

In business research, ethics was conceptualized as good business because corporations that follow ethical guidelines retain valued employees, increase productivity, prevent liability issues, and enhance customer trust (McDaniel, 2004). An ethical concern of public relations practitioners goes beyond worries about the profitability of enterprises. The term used to describe PR practitioners - the "ethical conscience of the organization" (Bowen, 2008; Pratt, 1991) — should be understood in the broader societal context. To be the ethical conscience of an organization means to pursue the ultimate goal: To contribute in the improvement of the overall ethical climate in society. This objective might be seen as a dream rather than a potentially achieved point by someone who believes in obviously realistic aims, but such important issues as ethics require high aspirations to make a difference. "Realistic" tasks might turn out to be low-level tasks that evoke apathy and the perception of a goal's unimportance, whereas high-level aims motivate and inspire to accomplish the difficult task. The moral behavior of a single PR professional contributes to the achievement of harmony (Paluszek, 1989), like a glass piece contributes in a mosaic picture.

Public relations scholars have developed some frameworks to analyze ethical dilemmas. Pearson (1989) created a dialogue-based approach. Bivins (1992) authored a 
systems-theory-based method where value is based on the approach's ability to "delineate a complex process and to wed it to an already accepted model of organizational decision making" (p. 381). Tilley (2005) developed a management approach that integrates proactive ethical decision making into every process, instead of waiting for ethical problems to arise. Bowen (2005) created a deontological analysis, which is, according to Berger and Reber (2006), comparable with PR professional and organizational codes of ethics. Deontological ethics, in Bowen's (2007a) words, "[R]equires that the respect and dignity of others be maintained in ethical decision making” (p. 281). Another ethical framework—-teleologicalstresses outcomes, or, "simply put, the ends justify the means" (Curtin \& Boyton, 2001, p. 411).

Curtin and Gaither (2007) overviewed postcolonial feminist ethics and identity ethics, two newer schools of ethical thought that have a potential to meet the challenges posed to PR practice by globalization. Postcolonial feminist ethics is concerned with "globalization's tendency to shift resources from the majority of the world's people and in oppression of all sorts" (p. 249). Identity ethics is based on the "hybridity and multiplicity of identities" (p. 250), respecting diversity, not difference. According to this field of ethical thought, "difference splinters and dichotomizes, dividing 'us' from 'them," whereas "identity ethics embraces diversity and pluralism, along with the cacophony of voices that often ensues" ( $p$. 250). A successful integration of both perspectives - postcolonial feminist ethics and identity ethics - into PR practice may lead to establishing a traitorous identity, which should not be understood as a disloyal self. Rather, this term implies PR practitioners' willingness to accept and value diversity and dissent; to learn from other cultures, not simply about them. 
Shamir, Reed, and Connell (1990) studied individual differences in ethical values of 198 American public relations practitioners. They concluded that although professional ethical norms usually are acquired and strengthened through a process of professional socialization, a greater emphasis on ethics education may help to "solidify the initial ethical level of new practitioners and thus contribute to their holding higher professional ethical values throughout their careers" (p. 963).

Ethics and social responsibility are an intrinsic part of public relations self-identity (L'Etang, 2003). The author argued that the term, "ethical guardian," is associated with a high status in society and with the status that attracts power and responsibility. To be in position to act as "ethical guardians," PR practitioners have to possess philosophical, sociological, and political knowledge. This is why PR education and particularly courses in media and business ethics are important for professional development. L'Etang concluded that because of criticism of the practice, ethics has always been of interest to PR practitioners and educators.

Nevertheless, when it comes to professional morality, public relations has been studied to some extent, whereas primary attention in communication scholarship has been given to journalism (Christians, 2008). Ideally, both groups of practitioners-journalists and public relations - intend to provide the public with factually correct information. However, as Day, Dong, and Robins (2000) pointed out, accurate information should not be equated with the truth. "Public relations messages are persuasive rhetorical messages and, as such, are not mere presentations of data" (Day et al., 2000, p. 406). In other words, messages evoke particular values, and this is why public relations discourse has to be ethical. 
Meanwhile, as recent research has shown (Berger, 2008), ethical values and orientation were not among prioritized dimensions of excellent public relations leadership. This survey of 162 members of the Southern Public Relations Federation (Berger, 2008) revealed that nearly half of respondents regarded problem-solving abilities, communication expertise, and strategic decision-making skills as the most important qualities, whereas only $23 \%$ mentioned ethics.

The challenge for contemporary public relations educators and practitioners is to link strategic and persuasive abilities with general morality. In this regard, Baker and Martinson (2002) proposed the TARES test, which is an acronym for five principles of ethical persuasion: Truthfulness, Authenticity, Respect, Equity, and Social Responsibility. Baker and Martinson (2002) suggested that the TARES test assists public relations practitioners in their communication practices by helping them weigh moral consequences of persuasion and thus, keeps persuasive messages ethical.

\subsection{Ethics Education: Historical Sketch}

This section briefly traces the two centuries-long history of ethics education in the U.S. by discussing how the university curriculum had been affected by the overall societal changes in the $19^{\text {th }}$ and $20^{\text {th }}$ centuries.

The place of ethics in the curriculum has reflected shifts in American higher education and broader academic and social trends for more than two centuries (Bok \& Callahan, 1980). In the early 1800s, moral philosophy occupied the central place in the college curriculum due to a widespread perception of education as the power that built a sense of national community through creation of common values. Therefore, as Sloan (1980) 
noted, moral philosophy was an essential component in the college curriculum and the national agenda.

In the $19^{\text {th }}$ century, moral philosophy was a required course for all senior students, who were expected to awake their ethical concerns and strive for developing moral characters. According to Sloan (1980),

$[\mathrm{T}]$ he nineteen-century moral philosophers saw the essential unity of the three dimensions of the teaching ethics: the cultural - the search for common values; the intellectual — the investigation of philosophic ground of values and moral action; and the individual — the formation of character and conduct (p. 9).

However, as a response to industrialization, a new social theory of higher education began to emerge in the late $19^{\text {th }}$ century. The primary function of colleges and universities became to educate not so much a "man of culture," but a "specialized expert" who would be able to manage society (Sloan, 1980). An emphasis on specialized training and ethicallyneutral and objective research changed the status of moral philosophy courses from required to elective in the majority of American universities in the early of $20^{\text {th }}$ century. As a consequence, only a small percentage of students studied ethics. In that time, scholars who believed in a quantitative approach to research were embarrassed over colleagues who viewed sciences as ethically oriented endeavors (Sloan, 1980).

Nevertheless, Ellwood (1910) argued against the separation of ethics from social sciences. In his opinion, one of the goals of social sciences was furnishing the raw material for ethics, which Ellwood called "a science of moral values, of moral norms and ideals" (p. 315). A similar idea that ethics as a normative discipline lies at the foundation of social sciences was articulated in the discussion of graduate training in ethics (Adams, Ducasse, 
Everett, Parker, Sharp, \& Turfs, 1932). The participants acknowledged a connection between teaching ethics and the increase in students' interest in the problems of contemporary life that emerged as moral dilemmas.

During the 1930s, the growing influence of scientific naturalism reinforced the general perception of ethical values as "noncognitive, nonrational, frequently as mere epiphenomena of underlying biological, economic, and social forces" (Sloan, 1980, p. 28). In that period, John Dewey developed his philosophic or ethical naturalism, which emphasized a connection between natural science and moral science. However, the movement known as logical positivism became dominant in the United States during the 1930s. Positivists undermined Dewey's theory, seeing ethical statements as lacking cognitive significance-as statements that could be only asserted, not rationally justified (Sloan, 1980).

Although by the middle of the 1960s ethics was generally freed from positivists' influence, ethics found itself even more isolated than ever in the college curriculum. According to Bok and Callahan (1980), in the middle of the $20^{\text {th }}$ century, ethics was taught almost exclusively in departments of philosophy and religion, and efforts to introduce ethics to other university units were generally rejected. As a consequence, there was a tendency, for example, in the business world to link the word, "ethics," exclusively to philosophical discussions of good and evil (Carey, 1947). This preconception disregarded ethics as a pragmatic concept and thus, prevented the development of professional ethics.

Leys (1950) discovered that students in ethics courses were able to give summaries of the principal systems of ethics, but they could not analyze their own problems in terms of these systems. The author called for rapprochement, or bringing together ethics and social sciences to help students learn how to make an ethical decision. In Leys (1950) opinion, 
courses in applied ethics were an important part of education because "ethics is presumably concerned with action" (p. 415).

Summarizing and oversimplifying, two centuries-long processes affected American higher education in general and teaching ethics in particular in the $19^{\text {th }}$ and $20^{\text {th }}$ centuries. The first development was the fragmentation of a single culture of learning into selfcontained disciplines of knowledge. Although moral philosophy was regarded as the root of many disciplines - economics, sociology, political science, and anthropology - the professionalization process led to the separation of the social sciences from teaching ethics at the end of the $19^{\text {th }}$ century.

The second development was associated with a widespread attitude toward literature, philosophy, art, and religion as not sources of knowledge, but as expressions of subjective preference or ideological inclinations, compared to natural sciences (Sloan, 1980). Consequently, most of the $20^{\text {th }}$ century is regarded as the period in which disciplines built on discourse of ethics did not have enough respect in the university curriculum.

\subsection{Modern Thoughts about Teaching Ethics}

This section focuses on a ground-breaking study of ethics education undertaken by the Hastings Center (Callahan \& Bok, 1980) in the 1970s in the U.S. and discusses research on modern universities' concern with the morality of their students and graduates.

The 1970s were proclaimed "the age of ethics" (Rosen \& Caplan, 1980), or the period of the rebirth of ethics education in the United States (Sloan, 1980). A report by the Hastingss Center (1980) stated that the convergence of many cultural and academic flows evoked the interest in moral philosophy at the college and professional school level. Particularly, symptoms of a moral vacuum, a sense of ethical uncertainty, juvenile and white- 
collar crime, a culture of narcissism, and the absence of fixed behavioral guidelines brought concerns about morality to the forefront. Within the universities, there was a concern that education did not equip students with knowledge and skills necessary to deal with personal and professional ethical dilemmas. On the part of research, scholars faced the need to reexamine relationships between knowledge and its ethical applications (Sloan, 1980).

Elliott (2007) said that in the 1970s, philosophers were no longer the only experts in ethics. Developmental psychologists and scholars from other academic disciplines were discussing ethics, developing codes of ethics, and introducing ethics education in undergraduate curricula. The term ethicist appeared in the 1970s to describe a person with ethical expertise, or someone who taught ethics or was a philosopher with academic interest in ethics (Elliott, 2007).

Acknowledging the fact that there is not an agreed-upon definition of the term "moral education," Callahan (1980) nevertheless proposed that ethics education is "an educational process with the goal of improving moral behavior, instilling certain virtues and traits of character, and developing morally responsible persons" (p. 71).

The report by the Hastings Center (1980) said that ethical principles are already being implicitly (Italic in original) communicated in various university courses, whereas the main goal of explicit teaching of ethics is "to uncover hidden assumptions, unchallenged and unexamined values, and treat the realm of morality with all the rigor and discipline that other areas of human study and concern already receive in the university" (p. 8). Callahan (1980) expanded the statement of the Report by articulating more precisely the goals of teaching ethics. They are to: 
1. Stimulate students' moral imagination, or evoke such emotions as empathy, sensibility, and caring.

2. Teach students to recognize ethical issues, or detect hidden value biases and see the moral implications of personal and collective decisions.

3. Elicit a sense of moral obligation, or highlight the necessity of ethical thinking: To act in accordance with the perception of right and good.

4. Develop analytical (logical) skills to help students analyze ethical propositions and their justification.

5. Tolerate and, thus, reduce disagreement and ambiguity while resolving moral dilemmas.

The formulation of the last goal has been modified to fit the era of globalization. Recently, scholars' attention has shifted from the problem of reaching consensus to the goal of managing dissensus in a global village (Curtin \& Gaither, 2007). Particularly, public relations was conceptualized as a "multicultural field that entails an ongoing competition and cooperation among a finite number of cultural voices" (Leichty, 2003, p. 277). Such a cacophony of voices calls for greater sensitivity to cultural diversity and pluralism; such an understanding becomes a synonym of ethicality, or obedience to moral conduct, in public relations.

Recognizing the contribution of the Hastings Center's (Callahan \& Bok, 1980) study into ethics scholarship, the researchers were nevertheless criticized for "moral neutrality" because they rejected the idea of direct impact of ethics courses on student behavior (Camenisch, 1986). A possible explanation for this is the desire to avoid indoctrination, 
which occurs when "someone attempts to inculcate a view without the intended learner's exercising his or her own reasoning ability” (Rosen, 1980, p. 187).

Nevertheless, "integrity must be proactive" (Nelson, 2003, p. 69), and educational institutions must be part of the resistance process to ethical misconduct because education itself is inherently ethical. It is hard to imagine that instead of teaching students to contribute to human welfare, they are taught to pursue self-interest for the expense of others by lying and manipulating. However, as Mendonca and Kanungo (2007) argued, the fundamental societal changes in norms and values resulted in the perception of education as an economic investment, whereas the "fundamental purpose of and reason for education - that is, the search for truth—is forgotten" (p. 7). Not surprisingly, some graduates of a prestigious university believed that money, fame, and power are main life achievements (Mendonca \& Kanungo, 2007).

Interestingly, another author (Rhode, 2006) mentioned the same school as an initiator of the process of ethical scrutiny of its applicants. The applicants are required to provide letters of recommendations in which applicants' integrity is ranked on a five-point scale; prospective students are also asked to discuss ethical problems that they have experienced. In this regard, Rhode argued that a new market of moral dilemmas is evolving: Keeping in mind the competitive nature of the admission process, some applicants might purchase "right" narratives and advice manuals to be admitted to this prestigious school.

Although an attempt by a number of U.S. universities to screen applicants for moral character might not look like an effective method to reduce the number of unethical students, it nevertheless reveals a growing concern of educators over what kind of values future practitioners possess and what kind of norms they will bring to the professional environment. 
The practice of ethical scrutiny also might be considered, however, as an attempt to avoid responsibility for having unethical graduates, uncertainty about the positive impact of higher education, and third, mere "window-dressing" for a university that desires to look "in tune" with the times.

In this light, a question arises whether ethics courses, being introduced into universities' curricula so rapidly these days, are able to contribute to student perceptions of education in its original meaning - as the process of acquiring knowledge and skills and developing character, and to have a positive impact on student moral development. As Boylan and Donahue (2003) put it, "Professional education [...] is more than simply the gaining of knowledge and technique. It is also an introduction to the moral framework that serves as the basis for the profession" (p. 91). To Boylan and Donahue (2003), to enter a profession means to enter an ethos, or a set of values and norms that constitute an environment in which the profession operates. Therefore, an overall task of higher education is to communicate to students professional values and provide them with an understanding of appropriate ways of professional practice.

\subsection{Commission on Public Relations Education about Ethics Education}

This section outlines the Commission on Public Relations Education's (2006) suggestions on how ethics should be taught in the public relations curriculum.

The Commission on Public Relations Education's (2006) report, The Professional Bond-Public Relations Education and Practice, is based on the findings of five research projects. The report included suggestions of course content for a PR curriculum. Courses that are considered essential for the proper preparation of students to meet expectations and challenges of modern PR practice are: writing and speaking skills; the fundamentals of public 
relations; strategic thinking skills, research skills; planning and problem-solving skills; ethics; the fundamentals of how organizations operate; and liberal arts and science.

Compared to the previous report (Commission on Public Relations Education, 1999), the Commission's most recent document paid more attention to the interplay between professional ethics, globalization, and cultural variables. Particularly, the Commission said that PR professionals, practicing abroad, should understand and follow international ethical standards and take into account cultural differences. However, they should be careful in taking questionable conduct as culturally predetermined. Even if such practices are commonly adopted within a local community, it might not mean that they are ethical and thus, a PR practitioner is not obligated to employ them.

Emphasizing the fact that modern public relations is defined by ethical standards, the Commission acknowledged the importance of PR professional education as the process of defining and teaching professional ethics; as education that helps students to acquire skills necessary to identify and resolve moral dilemmas in a way that leads to an ethical outcome.

The Commission recommended that discussion of ethical issues should pervade all content of PR professional education, especially in such courses as Introduction to PR, Campaigns, Case Studies, and, of course, Law and Ethics. Acknowledging the fact that PR curricula may not have room for a free-standing PR ethics course, the Commission suggested a one-hour course or a mini-seminar on PR ethics at the undergraduate level. As for the graduate level, the Commission advocated seminars in PR ethics and encouraged doctoral students to consider public relations ethics as a primary area of academic analysis.

The Commission stated that mass media ethics courses should not substitute for PR ethics course because PR practitioners duties are not limited to media relations. Rather, PR 
professionals should be viewed as "counselors who are knowledgeable - theoretically as well as technically—about communication in its broadest and most philosophical sense" (p. 23).

Acknowledging the fact that PR practitioners have the freedom to determine an ethical framework for their actions, the Commission nevertheless emphasized that the behavior of professionals must be consonant with publics' expectations. Moreover, PR practitioners are expected to influence the behavior of their organizations through their ideologies and values. This is why it is so important to teach these values to PR students. By integrating moral principles in practices, future PR professionals will contribute to "a morally defensible body of professional ethics“ (p. 24).

\subsection{Goals of Teaching Ethics and Value to Students of Ethics Education}

Since the educational process is defined and shaped by goals that teachers want to achieve, this section focuses on scholarship in various academic disciplines that address the issue of goals in teaching ethics.

Many academic branches - communication, business, law, public administration, political science - are concerned with their graduates' ethical behaviors. This is why the problem of teaching ethics seems to be cross-disciplinary. There are ongoing debates on the goals of ethics education and evaluation of student learning (Lee \& Paddock, 1992). HeikaEkins (1988) analyzed scholarship on teaching ethics in the public administration programs. She concluded that debates were concerned with two issues: whether courses should improve the moral cognitive capacities or cultivate moral character. While the majority of the public administration scholars saw the second task unattainable, other scholars believed that to teach students to vigorously rationalize their choices does not mean to prepare them to perform 
their duties in a democratic society. The primary goal of ethics education then becomes a cultivation of a moral frame of mind.

Although Callahan (1980) doubted that such a goal as improving moral behavior is realistic, he did not diminish the importance of ethics education, seeing its goal in helping “students develop a means and a process for achieving their own moral judgments" (p. 71). By the same token, Lisman (1996) saw the overarching goal of teaching ethics as helping students develop their capacities to become "contributing members of a liberal democratic society" (p.68). Thus, when teachers pursue this goal, students presumably benefit from such an education by performing their professional roles in accordance with societal expectations. Lisman identified the following capacities that students should develop in their undergraduate years: (1) autonomy, meaning to be self-directed and responsible; (2) fairness, the ability to regard self-interest impartially; and (3) citizenship, meaning to work cooperatively rather than competitively with others and to understand the democratic decision-making process.

A meta-analysis of studies on moral orientation (Jaffe \& Hyde, 2000) showed that the type of moral reasoning (the care or justice orientation) is not gender differentiated but depends on the context and content of the dilemma. However, the general public as well as students have different degrees of ethical capacity which "consists of knowledge, skills, perspectives, and motivations" (Johnson, 2005, p. 50). It means that they have different degrees of readiness to absorb and comprehend ethics lessons. J. D. Wallace's teaching experience showed that some students could not understand more than a simple phrase, "If you violate ethics, you go to jail," whereas other students were capable to grasp much more subtle and complex issues of moral choices and social responsibility (personal 
communication, November 15, 2007). One of the goals of ethics education is to raise the level of ethical capacity to prepare students for a PR career (Coombs, personal communication, November 15, 2007).

Sloan (1980) pointed out that in their pursuit of social harmony, the $19^{\text {th }}$ century philosophers tended to avoid potentially conflicting issues, such as the question of slavery (p. 8). Internal weakness is one of the reasons why moral philosophy in the undergraduate curriculum did not survive the $19^{\text {th }}$ century. Applying this history lesson to today, a suggestion would be to encourage ethics teachers to talk about controversial issues, for example, relationships between blacks and whites in the U.S, or the subject of the area of political correctness, which seems to be an avoided discourse in the reality. Accordingly, a goal of ethics education might be to inspire students to confront or (and) manage controversial issues rather than to avoid discussing them.

One of the topics discussed during the Training and Development Division's panel at the 2007 National Communication Association annual meeting was students' cheating in ethics courses. Surprisingly enough, discussants said, students who are being taught to value moral principles might cheat on exams and practice plagiarism while writing papers. A question arises, whether students are not willing to attune to ethics, or the ethics course itself is not effective. Obviously, every such case deserves separate scrutiny, but an overall conclusion that one might draw is pretty clear: Ethics education is much more complicated than it might appear at first glance. It appears to require experience, knowledge, creativity, and inspiration from a teacher who must be able to induce a true and long-lasting interest in ethics in the student audience. A goal of teaching ethics should be creating a chain that starts 
with evoking interest in ethics that leads to strengthening ethical inclinations, which has a potential to result in institutionalization of ethics into management decision-making.

To examine public relations instructors' perceptions of goals of ethics education and value to students of ethics education, the following research questions are proposed:

RQ 1: What are public relations teachers' perceptions of the primary goals of teaching ethics to public relations students?

RQ 2: What are public relations teachers' perceptions of the value to students of ethics education?

These two questions will also be examined through a variety of demographic variables - gender, academic rank, country of birth, country in which a respondent currently teaches, years of teaching experience, completion of a free-standing ethics course, experience in PR industry, whether a respondent has taught a separate ethics course, and so forth.

\subsection{Ethics Education in University Curricula}

This section discusses recent research on public relations educators and practitioners' perceptions of two fundamental questions in the educational process - what and how to teach public relations majors.

The public relations curriculum has been changing constantly to reflect societal changes (particularly, technological) since 1923, when the first public relations undergraduate course was offered at New York University (Boynton, 2002). However, for almost a century, educators and practitioners have been in consistent agreement that public relations training should not be limited to cultivating pure communication skills (writing and public speaking), but also include such disciplines as social sciences, business management, and philosophy. 
American scholars have paid increasing attention to the importance of teaching professional ethics in education and to what ought to be taught (Gale \& Bunton, 2005; Hutchinson, 2002; Neff, Walker, Smith, \& Creedon, 1999; Stacks, Botan, \& VanSlyke Turk, 1999).

A survey of 258 PR educators and practitioners indicated a general agreement with what should be included in the PR curriculum (Stacks, Botan, \& VanSlyke Turk, 1999). Although educators scored higher $(\mathrm{M}=6.37 ; S D=0.96)$ than practitioners $(\mathrm{M}=6.21 ; S D=1.06)$ on the variable "Ethics," a statistically significant difference was not detected, meaning that both groups valued ethics education.

Neff, Walker, Smith, and Creedon (1999) examined perceptions of outcomes, or the desired characteristics of PR practitioners or educators, and found that the two groups were in strong agreement regarding the training and experience outcomes required for career development in PR. Particularly, both educators and practitioners underlined the importance of adherence to ethical standards, PR codes, and understanding of the social consequences of PR practice.

A recent study (Wright \& Turk, 2007) indicated a large disconnect between public relations education and occupational practice. The researchers suggested several reasons for this gap. First, while educators claim that practitioners do not understand and appreciate the theoretical component of public relations, practitioners point out that PR education does not correspond with requirements of the modern business. Second, the extremely small travel budgets discourage educators from attending conferences and other gatherings where practitioners present. Third, public relations education is treated unfairly in many journalism schools. Wright and Turk noted that although public relations majors might outnumber 
journalism majors, journalism faculty members still outnumber public relations faculty members. Fourth, there is a lack of agreement between educators and practitioners about a common research agenda. While practitioners stress the need for applied studies, educators emphasize the need for theoretical research.

Obviously, there is the need for a constant dialogue between educators and practitioners. Exchange of ideas and opinions will result in developing a balanced curriculum that will help future graduates meet expectations of employers and at the same time, satisfy academia with an appropriate level of theoretical knowledge.

Heath (1991) argued that when the discipline is on its way toward professionalism, curriculum may follow or even lead. It might be argued that the impact of education on the profession comes from educators' dedication to frame each class as an ethical issue, regardless of whether a free-standing course in communication ethics is present in the curriculum or not. Hutchinson (2002) suggested that educators should focus "more on what we morally should do" instead of emphasizing "what we legally can’t do" (p. 308). In other words, more value should be attached to developing obedience to ethics codes than to teaching students to comply to avoid lawsuits.

This leads to an issue of ethics training versus ethics education. To train students to recognize and properly react to potentially problematic situations in public relations practice is an important task. Ideally, an outcome of training is knowledge of how to resolve ethical dilemmas, whereas ethics education helps future practitioners explain their choices and see consequences of their decisions (Coombs, personal communication, November 15, 2007). This is why training is only a part of education, and the latter cannot be limited to or substituted by the former. According to Bowen (2007b), moral philosophy provides public 
relations practitioners with ethical decision-making guidelines to solve complex moral dilemmas with integrity while communicating in the public interest.

Acknowledging the fact that public relations professional ethics is largely based on personal ethics, the Commission on Public Relations Education (2006) nevertheless called for an emphasis on ethics in all content of public relations professional education. Although scholars' opinions about the best methods to teach ethics vary, they agreed that ethics should be taught across the curriculum (Elliott \& Koper, 2002; Hutchinson, 2002; Parkinson \& Ekachai, 2002; Coombs \& Rybacki, 1999; Toth, 1999; McInerny, 1997-1998; Bivins, 1991; Pratt, 1991; Harrison, 1990; Shamir, Reed, \& Connell, 1990). Moreover, Harrison (1990) argued that a separate course in ethics should be required. Harrison (1990) surveyed 134 department heads and instructors and found that 97 percent of them "strongly agreed" or "agreed" that ethics is essential in PR education. By the same token, Bivens (1991) argued that "until our programs have reached a stage in which ethics is a required course for all those taking public relations, we will continue to give ill services to our students" (p. 44).

Toth (1999), discussing three models of a PR curriculum proposed by the Curriculum Task Team at the National Communication Association 1998 Summer Conference, argued that the three models advanced PR education because they advocated ethics across the curriculum and in separate courses. In this regard, this research will examine the following question:

RQ 3: What do teachers believe is the place of ethics in the PR curriculum, i.e., ethics should be a free-standing course, taught throughout the curriculum, or some other approach? 


\section{7. $\quad$ Pedagogies in Teaching Ethics}

This section focuses on pedagogies that communication educators found to be effective in teaching ethics to undergraduate students.

Ethics education starts with ethical self-identification. To deal with world diversity, a public relations practitioner first needs to have a sense of self-identity and understand his or her own values (George, 2003; Allert, 1999). This task is consistent with the role of PR professionals as the consciences of their organizations (Bowen, 2008; Pratt, 1991). The fact that PR executives do not become the "consciences" over night, calls for more thoughtful and rigorous pedagogies that will help students realize that ethics is the foundation for decisions and strategies in their professional lives.

Coombs and Rybacki (1999) defined pedagogy as "the delivery of course content" (p. 56) and identified the top 5 instructional delivery techniques based on a survey of PR teachers. This list included dialogue/class discussion, exercises/application of concepts, lecture, small group discussion, and group work. The authors argued that the biggest concern of communication educators was creating a dialogue about how PR theory and practice were presented to students and what they learned in classrooms.

Hutchinson (2002) provided practical advice regarding how to incorporate ethics throughout the curriculum. For example, she suggested that teachers ask students to develop their own codes of ethics during the principles course, whereas the PR campaigns course is suitable for group discussions of divided loyalties, or ethically soliciting new business. Almost any case in the cases in PR course has an ethical dilemma. While preparing individual presentations, students learn to identify an ethical problem and analyze how it was handled by the company that had faced crisis. 
Emphasizing a complexity of ethics education, Goodpaster (2002) noted that it is reasonably well-known how to communicate information and intellectual skills in a university environment; and it is reasonably understandable that ethics means "cultivating a moral outlook." However, educators' understanding tends to weaken when ethics and education intersect. The author suggested that a valuable approach to gain instructional strength is to employ the case method, a pedagogy that offers the learner an opportunity to exercise both moral and managerial judgment.

A Socratic method as an alternative pedagogy to a traditional lecture format was found more effective in developing students' critical thinking capacity and ability to solve practical PR problems (Parkinson \& Ekachai, 2002). However, researchers warned that because of a certain degree of anxiety associated with the class recitations, the Socratic course is best suited for successful PR students, whereas less academically advanced students might avoid it.

Misunderstanding of the nature of ethics education by public relations practitioners and other media practitioners is another academic concern. Christians (1979) worried about superficiality of ethics courses, when a simple discussion of classical cases or sensational situations constituted an ethics course. Plaisance (2007) echoed that concern. He argued that a teacher's goal is not providing students with the "right" answer for an ethical dilemma; instead, the teacher should concentrate on cultivating students' analytical skills. This is why a Socratic approach that reflects the discursive nature of moral philosophy is one of the best strategies to teach ethics at a university.

A survey by Sparks and Conwell (1998) found that PR teachers' pedagogy depended on the course level. Respondents reported using a lecture format for teaching low-level 
courses, whereas in upper-level courses, they mainly employed a more informal, group-based approach. Bunch (2005) found 30 hours of small-group discussions of ethical dilemmas helped students improve their moral reasoning score, whereas those students who had fewer hours of discussions or lectures did not.

Negotiation as a model for teaching PR professionalism was proposed by Saunders and Perrigo (1998). They argued that this model is an effective way to teach students to simultaneously consider ethical issues and pragmatic business needs while paying attention to the human element. Such a balance or the combination of ethics and skills is the essence of professionalism.

In general, any method of teaching ethics should work toward the goals a teacher chose (Callahan, 1980). Acknowledging the importance of public relations pedagogy, the next research question is proposed:

RQ 4: What do teachers believe are the most effective pedagogies in teaching ethics to public relations students?

\subsection{Resources in Teaching Ethics}

This section discusses ways communication educators employ conventional (e.g., textbooks) and unconventional (e.g., controversial movies) resources in teaching ethics.

To enhance student learning, PR instructors employ various methods and teaching resources (Boyd, 2004). Sparks and Conwell (1998) surveyed 90 U.S. schools and found that more than half of respondents treated textbooks and trade publications as primary teaching resources. Coombs and Rybacki (1999) agreed that textbooks are the foundation that determines pedagogy for a course. However, educators showed a general dissatisfaction with 
available textbook options. Also, they complained about the scarcity of such teaching materials as simulations, games, and videos. As Coombs and Rybacki noted,

$[F]$ ew faculty are creating these materials because tenure and promotion committees may disregard the importance of writing textbooks and creating pedagogy tools.

Through professional and academic bodies, public relations educators need to work to enhance the importance placed on pedagogy-related activity by bodies that evaluate faculty (p. 61).

Bivins (1989), evaluating six leading PR textbooks, concluded that the texts did not offer a conceptual framework from which to study PR ethics. The author contended that in a university environment, the question of ethics should be explored in the same degree of thoroughness as it was examined in the practice. This is why an adequate text was essential in the process of student discovery of ethical challenges.

Boyd (2004) noted that while there were a variety of introductory communication textbooks, texts for upper-level classes were not always congruent with course content. As an unconventional solution for the problem, the author suggested using novels in the classroom discussions. Novels, according to Boyd, "[S]erve to contextualize communication strategies and provide learning opportunities for students by engaging them in critical thinking and writing" (p. 341).

Controversial films as a teaching resource were found useful in classroom discussions of ethically complicated situations (Berger \& Pratt, 1998). The authors showed two David Mamet's films to upper-level PR students and discussed them in focus groups. The researchers found that while associating the movie characters' antics with those of business- 
communication practitioners, students were engaged in a thought-provocative environment. Such active learning is important for strengthening ethical responsiveness of college students.

The Internet as the venue to communicate organizations' ethics, image, and social responsibility is a modern concern of PR educators (Worley, 2007). In Worley's opinion, in the era of globalization, communication and relationship development has become more efficient and at the same time, more complex. Because virtually every stakeholder group can be reached through an organization's Web site, communicating truthful ethical philosophies and practices is an important task of a PR professional. An implication for teaching ethics is to inspire future PR professionals to be ready for a global dialog grounded in values of truth telling and responsibility.

Day et al. (2000) also considered such technologies as the Web and Internet to be suitable for dialogic communication between members of organizations and publics. It implies that organizational websites might be a good resource for teaching ethics in the era of digital media. However, Coombs and Rybacki (1999) noted that public relations teachers were slow to use new technologies in their classrooms.

RQ 5: What do teachers believe are the most effective sources or materials used for teaching ethics to public relations students?

\subsection{Techniques for Evaluation of Student Learning}

Since the evaluation of student learning has acquired a special importance at Western universities, this section outlines recent scholarship on methods that educators employ to examine the effectiveness of ethics instruction.

Almost 20 years ago, Stacks and Wright (1989) noted that the academic community generally agreed that "ethics can be taught” (p. 54). They expanded Ryan and Martinson's 
(1984) study of ethical values of PR practitioners with media students, intending to determine the effect of teaching ethics at a university. Stacks and Wright argued that facing an ethical dilemma, PR practitioners made judgments on the basis of their experiences, whereas students did not have such experiences and thus, their ethical choices should stem from an ethics course. The researchers found that compared to practitioners, students did not have the same degree of decision-making confidence.

In general, studies that have examined the impact of ethics instruction on university students brought mixed results. Ludlum and Mascaloinov (2004) noted only modest differences in ethics perceptions between business students who took an ethics course and those who did not have ethics education. Nevertheless, the authors advocated ethics courses by arguing that years in a college might be the only time when students engage in ethics discussions. These years are crucial because the views shaped in the college would reflect industry's climate for the next 30 years.

Lord and Bjerregaard (2003) examined the impact of a semester-long criminal justice ethics course on the students' value orientation and found that an educational ethics course can be influential, but a single course appeared to not produce the long-term change necessary to affect values and behavior. The authors argued for the necessity of multiple exposures to ethics material to make an impact on students' future behavior. By the same token, Chonko (2004) argued that ethics cannot be taught in a single course, but rather an ethics component must be infused into the entire curriculum to insure student moral development.

Lee and Padgett (2000), examining the impact of media ethics course on journalism students, found that the course did not affect students' moral values. However, the 
researchers suggested that training in systematic moral reasoning might help moral individuals avoid involvement in immoral decisions or actions, in which they otherwise might take part because of ignorance. This suggestion was supported by a number of psychological studies. Scholars argued that while some people intend to act unethically, others do not discern the moral features of the situation they face, and this is why they do not initiate the moral decision-making process (Reyhold, 2006). This implies that by improving moral awareness, or individuals' recognition of a moral problem in a situation (Rest, 1986), potential ethical disasters can be avoided.

Gale and Bunton (2005) surveyed 242 alumni with majors in public relations or advertising and found that graduates who had completed a media ethics course were more likely than those who had not to value ethics more highly, better identify ethical issues, and view personal and professional ethics as indistinguishable.

Hanson (2002) found in his study of journalism students and professionals that both groups prioritized the workplace before the classroom as the best place to learn about ethics, whereas Surlin (1987) found that media ethics course made issues of freedom and equality more salient to students at the end of the course.

The Report by the Hastings Center (1980) identified a few traditional modes of evaluation of student learning that are common for humanities courses, including ethics courses: classroom performance, tests, diaries, and written papers. Additionally, Rosen and Caplan (1980) suggested such techniques as (1) interviews with students to examine their ability to project classroom material to a particular situation and (2) games and simulations as the methods to test students' ability to analyze hypothetical situations. The researchers also mentioned nontraditional sources of information about student learning, for example, 
observation outside of the classroom and the usage of a standardized test or scale to measure cognitive change as a consequence of ethics course. Meanwhile, the Report (1980) emphasized teachers' attention to student performance by stating, "The ability to identify ethical issues, to apply theory to practice, and to show a mastery of ethical theory can all be ascertained by instructors who carefully attend to what students say in class and on paper" (p. 67-68).

In her ethics course, Elliott (2007) used ethical dilemmas for pre- and posttest measures. Essays that students wrote at the start of the term are given back to them at the end of the semester. In posttest, students are asked how they would approach the problem differently now, or to demonstrate "the degree of self-recognized growth" (p. 44) in regard to ethics.

In PR education scholarship, Hutchinson (2002) mentioned the assessment tools that the Integrative Team from the 1998 NCA Summer Conference recommended to employ in ethics courses: “[W]ritten examinations, written case studies, individual and panel presentations, term papers, group and individual projects" (p. 302). Presumably, the number of evaluative techniques PR instructors use in their courses is not limited to the Team's list, and one of the goals of the present study is to possibly expand the list made eight years ago. Acknowledging the fact that any university course should incorporate teachers' efforts to evaluate student learning, the next research question is proposed:

RQ 6: What are the most effective techniques for evaluation of student learning regarding ethics? 


\subsection{American and European Universities and Globalization}

This section discusses the interdependency of universities and societies in the era of globalization, and how differently this process has affected universities in the U.S. and Western Europe.

The university is the second oldest institution in the West (the first one was the Roman Catholic Church). Being a key to social mobility and progress, the university has had its status as a powerhouse for centuries (Rothblatt \& Wittrock, 1993). Yet, its high societal status does not guarantee its absolute autonomy from the challenges imposed by economic, political and social developments. In regard to the modern time, the globalization era has been labeled a threat that is more serious than previous epochs of scientific revolution, industrialization, secularization, and totalitarianism (Currie, DeAngelis, de Boer, Huisman, \& Lacotte, 2002).

It appeared that such a strong word as "threat" is used mainly to denote governments' attempts to force universities to become competitive players in the global market arena. Meanwhile, a number of scholars have argued that business-like behavior and concern about maximizing profit are not compatible with the purpose of higher education (Hostetter, 2007). As Adrian (2005) put it,

The modern university has become a political and economic force that has eroded its core identity and created a crisis of purpose in institution. The "free" search for "truth" has been lost in the rush to wealth and power, and economic development has become the principal objective rather than a derivative of higher learning (p. 153).

Trow (1993) remarked that historically, America's reliance on free markets turned the national system of higher education to dependency on market's needs in services and products. U.S. universities accept financial help from industry in return for research and 
future employees. Accordingly, students as consumers have shaped the university curriculum to meet expectations and demands of the job market. By contrast, in Europe, the market has not dominated the sphere of high culture (Trow, 1993). While U.S. universities perceive their role as contributors to technological and industrial development, European universities see their role as developing theory or contributors to knowledge for its own sake (Owen-Smith, Riccaboni, Rammolli, \& Powell, 2002). As an example, although the Dutch government is concerned with the economic aspect of higher education, nevertheless, the government leaves a certain degree of autonomy to the institution and thus, diminishes the presence of market mechanisms in the system of higher education (Currie et al., 2002).

However, Rothblatt and Wittrock (1993) argued that recent developments in Europe (e.g., the collapse of Soviet regimes, the disenchantment with State planning and large-scale bureaucracy) have led Europe to a search for new models of higher education. Since the theme of the market in higher education has acquired global attention, American models have attracted "special international interest."

Caddick (2008) said that over the past 50 years, European universities that were traditionally recognized as flagmen of higher education for almost a thousand years lost their world leadership to U.S. universities. To address this problem, the European academic community initiated the so-called Bologna Process, which among many other goals seeks to apply the UK/US degree structure (bachelor, master, and doctoral degrees) to universities in 46 European countries to create "a single education currency" (Caddick, 2008).

The revolution in communications has allowed more frequent exchange of ideas among international academic communities and provided more opportunities for the crossfertilization. Like never before, scientific ideas are readily accessible and thus, subjects of 
adaptation and assimilation (Rothblatt \& Wittrock, 1993). Coupled with an increasing level of intercultural communication that might lead to the decrease in the strength between the territory and social identity and the emergence of a "global consciousness" (Rizvi, Engel, Ruthkowski, \& Sparks, 2007), the sovereignty of a particular university as a policy-maker becomes questionable. Indeed, there are growing tensions between the historic mission of the university as the transmitter of ideas and values (Hostetter, 2007) and the necessity to respond to market demand and competing economies. As Currie et al. (2002) argued a shift from cooperation to competition has already happened in the higher education system worldwide. This shift has not been welcomed by the entire academic population (Seccion Especial, 2004) since this process as many others that originate in the West is associated with Americanization (Hall, 1991).

While universities have been coerced by governments to become more market oriented, practitioners, particularly those who work in public relations believed that globalization is "forcing the need to clearly articulate the essence of the brand-its values, its ethics and its principles" (Hayes, 2008, p. 16). The role of public relations education as the process of immersion into the profession is not limited to the transmission of professional knowledge and skills, but it is also concerned with introducing professional beliefs and values to students. Moreover, public relations students should receive a well-rounded education that serves as a precondition for a fulfilling life.

This study will examine the following question:

RQ 7: In regard to ethics instruction in public relations, do teaching philosophies and practices differ depending on where — in the U.S. or Europe — respondents teach? 
This question will be explored through semi-structured interviews with U.S. public relations educators and university teachers from Germany, the Netherlands, and the United Kingdom.

Thus, this study employs both survey and interview approaches with public relations educators in the U.S. and Western Europe to attempt to answer seven research questions regarding ethics and public relations education. The results will provide a baseline of information about current ethics perceptions and teaching principles in public relations. The results also may help stimulate future studies in the area and advance teaching of ethics. 


\section{CHAPTER 3}

\section{METHOD}

The study employed a survey and interviews. The survey was used to examine RQ 16 , and it is first discussed and described in this section.

\subsection{Quantitative Survey}

\subsubsection{Participants.}

Participants in this study were 249 public relations teachers in the U.S. $(n=211)$ and foreign universities $(n=38)$. The sample included full-time university or college teachers, e.g., instructors, assistant professors, associate professors, and professors. The combined membership lists of the Association for Education in Journalism and Mass Communication, International Communication Association, National Communication Association, and Educator's Academy of the Public Relations Society of America contained names of approximately 670 PR educators. Members of these associations included many American PR teachers, as well as those from many other countries. The number of potential participants was not large, and thus a census of the population was used. As members of academic organizations, all participants were fluent in English and foreign translations of the informed consent document and survey were not necessary. 


\subsubsection{Instrument.}

To assess public relations teachers' attitudes toward teaching ethics in the undergraduate and graduate curricula and examine teaching approaches, a two-part questionnaire was developed (Appendix I). The questionnaire and subject areas were based on academic scholarship on ethics and ethics education. In addition, the questionnaire was tested through personal communications with eight teachers who are recognized leaders in public relations education in the U.S. Half-hour interviews with them were conducted during the National Communication Association convention in November, 2007, and their feedback was used to refine the questionnaire and subject areas.

The first part of the questionnaire was designed to answer the six research questions outlined earlier. Sections 2 and 4 of the first part examined the first two research questions, e.g., teachers' perceptions of the primary goals of ethics education and value to public relations students of such an education. For the purpose of this study, "ethics education" was operationalized as "an educational process with the goal of improving moral behavior, instilling certain virtues and traits of character, and developing morally responsible persons" (Callahan, 1980, p. 71).

In contemporary philosophical use, the word, "ethics," might mean normative, descriptive or meta-ethics. The present study is concerned with normative ethics because it examines actual moral arguments and judgments, bringing people's responses to ethical dilemmas to the forefront. Seeing applied ethics courses as normative enterprises, Camemisch (1986) argued that they have two impacts on students: enhancing autonomy and shaping their morality. When affecting students' moral lives, the teacher targets three 
dimensions: cognitive (students' ability for moral reasoning), affective (their feelings, values, and convictions), and active (students' actual choices and actions).

Applied ethics is within the domain of normative ethics, according to the Report by the Hastings Center (1980). Applied ethics is about "making actual (Italic in original) choices in moral conflicts" (p. 15). Applied ethics is interdisciplinary because it is concerned with human conduct that is affected by political, cultural, psychological and other factors. Goodpaster (2002) argued that in the $20^{\text {th }}$ century, moral philosophy had been mostly concerned with the meanings of "right" and "good," whereas a question of what actions are right was excluded from the philosophical discussion. As a result, an intellectual and cultural gap appeared between ethical theory and management education. This gap is narrowing these days when in various universities, ethics and management are being integrated in a single course of applied ethics.

Professional ethics, which studies ethical problems that individuals encounter at work, is a part of applied ethics. A "public relations ethics course," "communication ethics course" or "ethics throughout PR curriculum" deal predominantly with public relations professional ethics. One of the goals of this study is to examine how - through what kind of pedagogies and techniques - professional ethics is taught at the university level today. Accordingly, sections 1 and 5 examine teachers' perceptions of the most effective format of ethics instruction delivery and the place of ethics in the university curriculum. Section 3 is designed to measure PR instructors' perceptions of (1) the most effective pedagogies; (2) the most useful resources in teaching ethics; and (3) the most effective evaluative techniques of student learning. 
A Likert scale is used to capture these perceptions. First, a 7-point Likert scale from "strongly disagree" to "strongly agree" was employed in the following sections: Format of Ethics Instruction Delivery, Goals in Teaching ethics, and Value to Students of Ethics Education. Second, a 5-point Likert scale (ranging from "very useless/very ineffective to very useful/very effective) was used for the sections that examine respondents' perspectives on pedagogies, resources, and assessment tools for evaluating ethics learning. A concluding section of the first part of the questionnaire asked participants to provide information about whether the curriculum includes an ethics course and indicate a possible reason of why a free-standing course in ethics is absent.

Fifteen questions about participant demographics were included in the final section.

\subsubsection{Pretest}

The questionnaire were pre-tested for question clarity and question applicability; 25 instructors and doctoral students of such departments as Communication, Journalism, Telecommunication and Film, Political Science, Philosophy, and Education of a large southeastern university were asked to fill out and comment on the questionnaire. Their comments were the basis for questionnaire revisions. The values sections of the survey were pre-tested for scale reliability, and Cronbach's alpha was .91.

\subsubsection{Procedure}

Email addresses of sample members were obtained through the membership lists of AEJMC, ICA, NCA, and PRSA Educator's Academy. Public relations instructors were contacted via emails and invited to participate in a web-based survey (Appendix II). Although this method has some limitations (for example, it allows multiple responses from a single individual or responses from individuals outside of the population of interest), a web- 
based survey offers such advantages as being low-cost and has the potential to reach greater numbers of people in a shorter period of time, compared to phone or mail surveys (Cook, Heath, \& Thompson, 2000; Sheehan \& Hoy, 1999).

A web survey also seemed preferable for this specific group of respondents- public relations instructors - for at least three reasons. First, compared to ordinary Internet users, teachers use emails on a regular basis because official departmental communication occurs largely through emails. Second, they are expected to have enough Internet experience or to be "Internet savvy:" The modern academic life is not imaginable without a constant search of various electronic databases and sites. Third, taking into consideration teachers' business, it is important that the participation in a web-based survey is less time-consuming, compared to a mail paper-based one. As for the response rate, it was found to be positively correlated with the salience of an issue (Cook et al., 2000).

Public relations instructors were contacted via emails and invited to participate in a web-based survey in April 2008. The email had a link to a web site with the questionnaire. The web site was constructed via Zoomerang after obtaining IRB approval for conducting the study. The first page of the web site contained a participant informed consent form (Appendix III). In May and June 2008, two reminder emails were sent to encourage instructors to participate. The survey took approximately 20 minutes for the participants to complete.

\subsubsection{Response rate}

When a population consists of 650 individuals, the sample should be not less than 242 participants to generalize to the rest of the population (Wrench, Thomas-Maddox, Richmond, \& McCroskey, 2008). Of 669 emails sent, 69 messages were not delivered and 16 potential 
respondents emailed back saying they do not teach public relations courses anymore. Of 584 participants who presumably received invitations to participate in the study, 282 teachers responded. The response rate was estimated as $43 \%$ based on 249 complete responses. However, incomplete responses that missed not more than 3 questions were also included in analysis.

\subsection{Interviews with U.S. and European teachers}

This section reviews the interview approach used to assess RQ 7.

\subsubsection{Participants.}

To examine teacher perceptions of ethics education, semi-structured interviews were conducted with a purposive sample of 52 American $(n=32)$ and European $(n=20)$ educators. The sample was selected to represent different nationalities, genders, age groups, and teaching experience. The American participants were recruited and interviewed during two national and two international conventions during 2007 and 2008.

The researcher undertook a trip to Europe to meet communication educators in seven universities in the United Kingdom, the Netherlands, and Germany. Appointments with them were made via email before the trip, and face-to-face interviews were conducted in their offices in October-November 2008.

The overall sample consisted of 30 males and 22 females with the age range from late twenties to early sixties. Six participants had a Master degree and 46 had a Doctorate degree. The majority of participants had their degrees in Communication and related fields, and their teaching experience at the university level varied from 2 to 40 years.

Both groups of educators - American and European — included recognized leaders in public relations education, who have published numerous journal articles and book chapters 
and have served as editors and co-editors of communication journals and books. Some of them were well-known experts in public relations ethics and communication ethics. These individuals have known each other and collaborated with each other for many years, and thus, similar attitudes could be formed among the colleagues. Thus, to assure the variance of the data, some junior faculty were purposively included in the sample.

\subsubsection{Instrument.}

The questionnaire for semi-structured interviews was designed to validate and supplement results of the quantitative study. To capture a deeper understanding of teacher perceptions of ethics education, 10 open-ended questions were developed (Appendix IV). As an example, while the quantitative questionnaire asked respondents to indicate their attitude on the statement, "Ethics instruction in public relations education is essential" on a 7-point Likert scale, a qualitative questionnaire contained such a question as "Do you think ethics education is essential for public relations students? Why?"

Although a few questions included in the qualitative interview did not echo the quantitative questionnaire, they still targeted respondents' attitudes toward ethics instruction in the public relations curriculum. As an example, one of the questions asked, "Do you believe that ethics education has a long-term effect on PR students? On what kind of evidence is your opinion based?"

Marshall and Roswell (1989) suggested that qualitative in-depth interviews are more like conversations that help "uncover participants' meaning perspective" (p. 82). Therefore, the conducted interviews focused not only on collecting factual information (e.g., resources in teaching ethics), but also spotlighted respondents' opinions and values attributed to different aspects of ethics education. Moreover, during interviews, respondents were 
specifically asked to provide the interviewer with examples from their experience as public relations educators. This evidence became part of "thick description" (Denzin, 1994) of the data.

The interviews averaged 40 minutes in length. The participants agreed to audiotape their interviews which were then transcribed for analysis.

Interviews with European educators were conducted after the quantitative survey had been done. Therefore, Europeans had an opportunity to comment on some results, particularly those that revealed differences in perceptions of ethics education between U.S. and foreign public relations teachers. The fact that the researcher traveled to Europe from the U.S. and she is a European also might have contributed to respondents' willingness to compare American and European approaches in teaching communication students 


\section{CHAPTER 4}

\section{RESULTS}

This research yielded both quantitative and qualitative data. Quantitative data was analyzed using SPSS. Besides calculating descriptive statistics, a number of tests were performed: Analysis of variance, factor analysis, post hoc multiple comparison test, multiple regression analysis, correlation analysis, and Chi-squire. Internal consistency of an attitude scale was measured with Cronbach's alpha coefficient. Semi-structured interviews provided additional insight into the data gathered through the survey. The qualitative data was analyzed by using guidelines outlined by Lincoln and Guba (1985).

\subsection{Survey Results}

\subsubsection{Descriptive data.}

Of the 249 respondents, 124 were males and 125 were females. Fifty-two participants indicated that their highest degree was a Master's degree, and 194 teachers had Doctorate degrees. The majority of participants — $146(59.6 \%)$ — had the highest degree in mass communication $77(30.8 \%)$ and communication studies 72 (28.8\%). Forty-four participants $(17.6 \%)$ obtained their highest degree in public relations, and $15(6.0 \%)$ respondents specialized in journalism.

Other highest degrees were obtained in business, English, philosophy, political science, sociology, public administration, management, education, education administration, 
rhetoric, speech communication, law, environmental studies, economics, American studies, history, international relations/communications, rhetorical and communication theory, psychology, educational policy and leadership, and higher education.

As for academic ranks, 73 (29\%) of the participants were professors, 73 (29\%) were associate professors, $62(25 \%)$ were assistant professors, and 29 (12\%) were instructors. Thirteen (5\%) respondents had other academic ranks (professor emeritus, dean, endowed chair, senior lecturer, adjunct professor, and professor of practice).

Of those who reported, 171 participants $(68 \%, \mathrm{n}=251)$ taught graduate level courses. The majority of these respondents ( 68 or $40 \%$ ) reported that they taught two graduate level courses, whereas 61 teachers (36\%) taught one course each year (12-month period). The other 42 respondents (24\%) taught from three to six graduate level courses each year.

Two hundred and eight participants $(89 \%, \mathrm{n}=233)$ reported that they taught junior/senior level courses each year. Of these, 136 people (65\%) taught from 2 to 4 courses, whereas 47 respondents (23\%) taught from 5 to 12 courses each year. Twenty five people (12\%) taught one course during a 12-month period.

One hundred and fourteen participants $(47 \%, \mathrm{n}=242)$ taught freshmen/sophomore level courses each year. The majority of participants ( 77 or $68 \%$ ) taught 1-2 courses, whereas 26 teachers (23\%) taught 3-4 courses. Eleven respondents (9\%) reported that they taught from 5 to 12 courses at the undergraduate level each year.

Participants $(\mathrm{n}=237)$ indicated that they taught at the college or university level from 1 to 40 years $(M=13.62 ; S D=8.89)$. Out of 250,51 respondents $(20 \%)$ have taught a separate ethics course (PR ethics or communication/media ethics) at the college or university level. 
Eighty two participants ( $\mathrm{n}=250,33 \%)$ completed an ethics course when they were university students.

Two hundred and three participants $(\mathrm{n}=250,81 \%)$ said that they had worked or worked as PR practitioners; 190 respondents indicated the number of years they spent practicing public relations - from 1 to 40 years $(M=12.58 ; S D=8.95)$. Many respondents combined teaching and practicing public relations.

Out of 250, 192 teachers were born in the U.S., and 58 were born in countries other than the US. Two hundred and eleven respondents $(\mathrm{n}=249)$ currently teach in the US, whereas 38 participants teach abroad. Out of 249, 186 participants were born and they teach in the US, whereas five participants were born in the U.S. but they currently teach abroad (Australia, Ireland, New Zealand, and Norway).

Twenty-three respondents were born abroad (Australia, Canada, China, Columbia, Germany, Ghana, India, Middle East, New Zealand, Romania, Russia, and South Korea), but they currently teach in the US. Thirty-five participants were born and teach abroad. Some of them teach in their native countries (Australia, Canada, Finland, Grotia, Netherlands, Norway, Poland, Portugal, Russia, Singapore, Slovenia, South Africa, and Switzerland), whereas others teach in foreign countries other than U.S.

Respondents ( $\mathrm{n}=282$ ) were asked to indicate all of the professional and academic organizations in which they were members (Table 1). The largest organization was the Public Relations Society of America (161 participants). One hundred and forty-two respondents belonged to the Association for Education in Journalism and Mass Communication and 92 participants indicated their membership in the National Communication Association. 
Table 1. Membership in Professional and Academic Organizations ( $\mathrm{n}=282)$ Organization Number of respondents

1. Public Relations Society of America 161

2. Association for Education in Journalism and Mass Communication 142

3. National Communication Association 92

4. International Communication Association 86

5. Institute for Public Relations 34

6. International Association of Business Communicators 30

7. International Public Relation Association 18

8. European Public Relations Education and Research Association

9. Arthur W. Page Society

Other 97

On average, each participant was a member of two professional or academic organizations.

Sample demographics were compared to members of the organizations from which email addresses were obtained. The study sample was consistent overall in terms of gender and academic rank.

\subsubsection{Results.}

Overall, respondents perceived ethics instruction in public relations education to be essential. Taking in consideration the fact that the members of AEJMC, ICA, NCA, and PRSA Educator's Academy represented public relations instructors who teach in different parts of the world, the census was classified into four groups. The first group $(n=186)$ 
comprised respondents who were born and teach in the U.S., whereas the second group $(n=5)$ consisted of teachers who were born in the U.S. but currently teach abroad. The third group $(n=23)$ included respondents who were born in countries other than the U.S. but currently teach in the U.S., and the fourth group $(\mathrm{n}=35)$ consisted of respondents who were born and teach abroad. The second group was dropped from the analysis because of its small number - only 5 respondents reported that they were born in the U.S. but currently teach abroad.

Regardless of country of birth and country in which respondents currently teach, all of them rated highly the value of ethics instruction in the public relations curriculum $(n=240)$. A one-way ANOVA did not show significant differences among the three groups of participants regarding the importance of ethics instruction in public relations education, $F$ $(2,237)=2.889, p<.05$.

\subsection{Research Questions}

Other survey results are presented in response to each of the six research questions.

\subsubsection{Research Question 1}

\section{RQ 1: What are public relations teachers' perceptions of the primary goals of teaching ethics to public relations students?}

To examine public relations instructors' perceptions of the primary goals of ethics education, participants were asked to fill out a 5-item questionnaire using a scale from 1-7 with 1 indicating Strongly Disagree and 7 indicating Strongly Agree. This scale was internally reliable, resulting in a Cronbach's alpha of .77.

According to participants (Table 2), the highest-rated goal of ethics education is developing socially responsible professionals $(M=6.41 ; S D=1.09)$. The second most 
important goal was helping students make good choices on the job $(M=6.28 ; S D=1.15)$, whereas the third most valuable goal was improving the moral cognitive capacities of public relations students $(M=5.90 ; S D=1.20)$.

Table 2. Participants' $(n=282)$ Evaluations of the Primary Goals of Ethics Education.

Goals in teaching ethics $\quad$ M SD Rank

$\begin{array}{llll}\text { 1. To cultivate moral character. } & 5.23 & 1.58 & 5\end{array}$

2. To improve the moral cognitive capacities of PR students. $\quad \begin{array}{lll}5.90 & 1.34 & 3\end{array}$

3. To familiarize students with ethical theories. $\quad \begin{array}{lll}5.83 & 1.20 & 4\end{array}$

4. To develop socially responsible professionals. $\quad 6.41 \quad 1.09 \quad 1$

5. To help students make good choices on the job. $\quad \begin{array}{lll}6.28 & 1.15 & 2\end{array}$

Note: On a scale from 1-7, with 1 indicating Strongly Disagree and 7 indicating Strongly Agree.

To assess differences among the study participants, a set of one-way analyses of variance (ANOVA) with country of origin and country in which respondents currently teach as the independent variables and perception of goals in teaching ethics as the dependent one was performed (Table 3). The significance level established for all tests was .05.

The test indicated a statistically significant difference $(F(2,241)=4.648, p<.05)$ in participants' perceptions of the importance of such a goal as helping students make good choices on the job. Concerning the fact that the numbers of participants in the two groupsthose who were born abroad but currently teach in the U.S. $(n=23)$ and those who were born and teach abroad $(n=35)$ - were significantly less than the number of US participants $(\mathrm{n}=186)$, the number of American participants was reduced to 38 by selecting every fifth 
respondent. A set of one-way ANOVA indicated that the previous result was sustained: Participants still differed on the issue of whether ethics instruction contributes to students' ability to make right choices on the job $(F(2,93)=4.751, p<.05)$.

The means (Table 3) suggested foreign participants appeared to believe that ethics instruction helps students make right choices on the job significantly less so than did participants who were born and teach in the U.S. Post hoc pairwise multiple comparison (Bonferroni $t$ test) showed a statistically significant difference $(p<.05)$ between the group of respondents who were born and teach in the U.S. and those who were born and teach abroad.

Fifty-three $(19 \%, \mathrm{n}=282)$ participants named other goals of ethics education. The list provided by the respondents might be divided into four categories. The first category included 20 respondents who believed that a goal in teaching ethics was to create awareness of personal and professional ethical values and consequences of PR practice. As an example, one teacher wrote, "Make them [students] aware of moral dilemmas they may face." Another participant said that a goal of teaching ethics is "To understand the potential impact of PR."

The second group encompassed 16 responses that emphasized the necessity to educate responsible and active professionals who would be able "to pass on ethics to others." According to a participant, a goal of ethics education was to "help students understand ethics is their responsibility."

The third category consisted of nine responses that reflected participants' beliefs that a goal was to teach students to recognize ethical issues. As one respondent said, "To improve ability to identify ethical aspects." Another participant echoed the previous opinion, saying that a goal was to "recognize ethical issues (vs. agree without thinking)." 
The fourth category comprised opinions of eight participants who considered such a goal as "developing ethical decision making skills" as important in teaching ethics.

Table 3. ANOVA-test Comparison among Participants who Were Born and Teach in the U.S. $(n=186)$, Who Were Born Abroad and Teach in the U.S. $(n=23)$, and Participants Who Were Born and Teach Abroad $(n=35)$.

\begin{tabular}{lccccccc}
\hline & $\begin{array}{c}\text { US/US } \\
(\mathrm{n}=186)\end{array}$ & $\begin{array}{c}\text { Other/US } \\
(\mathrm{n}=23)\end{array}$ & $\begin{array}{c}\text { Other/Other } \\
(\mathrm{n}=35)\end{array}$ & \\
\hline Goals in teaching ethics & $\mathrm{M}$ & $\mathrm{SD}$ & $\mathrm{M}$ & $\mathrm{SD}$ & $\mathrm{M}$ & $\mathrm{SD}$ & $\mathrm{F}$ \\
\hline 1. To cultivate moral character. & 5.24 & 1.54 & 5.96 & 1.30 & 5.09 & 1.76 & 2.520
\end{tabular}

2. To improve the moral cognitive

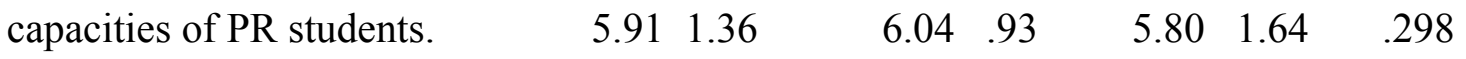

3. To familiarize students with

$\begin{array}{llllllll}\text { ethical theories. } & 5.85 & 1.18 & 5.65 & 1.07 & 5.77 & 1.52 & .298\end{array}$

4. To develop socially responsible

$\begin{array}{llllllll}\text { professionals. } & 6.45 & 1.06 & 6.30 & .88 & 6.11 & 1.47 & 1.427\end{array}$

5. To help students make good

$\begin{array}{llllllll}\text { choices on the job. } & 6.38 & 1.08 & 6.26 & .81 & 5.74 & 1.60 & 4.648^{*}\end{array}$

Note: On a scale from 1-7, with 1 indicating Strongly Disagree and 7 indicating Strongly Agree. $d f=2 ; *$ Significant at $p<.05$.

\subsubsection{Research Question 2}

RQ 2: What are public relations instructors' perceptions of value to students of ethics education?

To measure public relations instructors' perceptions of value to students of ethics education, a 15-item scale was developed (Table 4). Internal consistency reliability based on Cronbach's alpha coefficient for the value to students of ethics education was high $(\alpha=.91)$. 
Principal component factor analysis with varimax rotation was conducted in SPSS.

The eigenvalue for extraction was set at 1 ; item loadings had to exceed .50 on at least one factor; and a minimum of difference of .01 between loadings was required (Nunnally, 1978). The test revealed three main factors, with the strongest component (eigenvalue $=7.27$ ) loading on seven items, and it corresponded to $48.5 \%$ of the variance in the original data. The second eigenvalue was equal to 1.27 and was associated with $8.4 \%$ of the variance in the original data. The third eigenvalue (1.01), corresponding to the third factor, was associated with $6.7 \%$ of the variance in the original data. Together, the three factors explained $63.6 \%$ of the variance in the original data. The first factor was "moral character" (Cronbach's alpha is .87 ); the second factor was "moral reasoning" (Cronbach's alpha is .82); and the third factor was "professional skills" (Cronbach’s alpha is .72).

Factor 1 represented the perception of ethics education as education that contributes to overall moral development of public relations students and appeared to be the strongest predicting issue. Factor 2 represented the belief that ethics education should prepare students to use moral reasoning while solving ethical problems at the workplace. Factor 3 represented the perception of ethics education as the process of acquiring particular skills to deal with ethical dilemmas.

The study participants recognized the following statements as the most important in ethics education: Ethics education helps students become aware of ethical issues in PR $(M=6.31 ; S D=.90)$; Ethics education helps students develop tools for reasoning through ethical dilemmas $(M=5.77 ; S D=1.07)$; and Ethics education equips PR majors with the ability to make better moral judgments in business decisions $(M=5.64 ; S D=1.14)$. 
Such a statement as Ethics education does not create moral character $(M=4.39$; $S D=2.05)$ appeared to be the least essential, with the biggest standard deviation indicating diverse opinions on the issue of whether ethics education is able to form morality in public relations students.

A Pearson correlation coefficient was calculated for the relationship between participants' perceptions of goals in teaching ethics and their perceptions of value to students of ethics education. A moderate positive correlation was found $(r(249)=.398, p<.001)$, indicating a significant relationship between the two variables. The more respondents supported the goals listed in section 1 of the questionnaire (Table 2), the more they appeared to believe in value to students of ethics education, or vice versa.

The second correlation test examined the relationships between participants' perceptions of goals in teaching ethics and their perceptions of essentiality of ethics education. A moderate positive correlation $(r(265)=.514, p<.001)$ showed a significant relationship between the two variables. The more respondents believed in goals of ethics education (Table 2), the more they appeared to believe in essentiality of ethics education, or vice versa.

The third Pearson correlation coefficient was estimated for the relationship between participants' perceptions of value to students of ethics education and their beliefs in essentiality of ethics education. A moderate positive correlation $(r(249)=.374, p<.001)$ indicated a significant relationship between the two variables. The more respondents believed in value to students of ethics education, the more they considered ethics education essential, or vice versa. 
Table 4. Means and Factor Analysis for Value to Students of Ethics Education Scale Items

\begin{tabular}{|c|c|c|c|c|c|}
\hline \multirow[t]{2}{*}{ Statement } & \multirow[t]{2}{*}{$M$} & \multirow[t]{2}{*}{$S D$} & \multicolumn{3}{|c|}{ Factor loadings } \\
\hline & & & 1 & 2 & 3 \\
\hline Ethics education does NOT create moral character.* & * 4.39 & 2.05 & .79 & -.003 & .008 \\
\hline Ethics education positively affects & & & & & \\
\hline students' value systems.** & 4.98 & 1.16 & .69 & .39 & .25 \\
\hline Ethics education inspires students & & & & & \\
\hline $\begin{array}{l}\text { to be moral in their professional lives.* } \\
\text { Ethics education helps students develop }\end{array}$ & 4.99 & 1.34 & .68 & .44 & .29 \\
\hline $\begin{array}{l}\text { a sense of moral obligation. } * * \\
\text { Ethics education helps PR students realize }\end{array}$ & 5.14 & 1.28 & .67 & .49 & .12 \\
\hline that they have to be ethical to succeed.* & 4.71 & 1.37 & .63 & -.10 & .50 \\
\hline $\begin{array}{l}\text { Ethics education helps students maintain } \\
\text { integrity in their professional lives.** }\end{array}$ & 5.22 & 1.13 & .58 & .34 & .46 \\
\hline Ethics education helps students form an ethical & 3.22 & 1.15 & .50 & & .40 \\
\hline $\begin{array}{l}\text { frame of mind.** } \\
\text { Ethics education helps students }\end{array}$ & 5.31 & 1.12 & .54 & .38 & .42 \\
\hline become aware of ethical issues in PR.** & 6.31 & .90 & .01 & .78 & .11 \\
\hline $\begin{array}{l}\text { Ethics education helps students develop tools } \\
\text { for reasoning through ethical dilemmas.* }\end{array}$ & 5.77 & 1.07 & .19 & .63 & .48 \\
\hline $\begin{array}{l}\text { Ethics education equips PR majors with } \\
\text { the ability to make better moral judgments }\end{array}$ & & & & & \\
\hline in business decisions. ${ }^{*}$ & 5.64 & 1.14 & .50 & .61 & .15 \\
\hline $\begin{array}{l}\text { Ethics education helps students understand } \\
\text { their personal values.* }\end{array}$ & 5.38 & 1.21 & .34 & .57 & .42 \\
\hline $\begin{array}{l}\text { Ethics education teaches students to use moral } \\
\text { reasoning to help resolve conflicts.* }\end{array}$ & 5.36 & 1.16 & .46 & .55 & .31 \\
\hline $\begin{array}{l}\text { Ethics education helps students develop strategic } \\
\text { thinking skills.* }\end{array}$ & 5.21 & 1.27 & .16 & .18 & .79 \\
\hline $\begin{array}{l}\text { Ethics education arms PR students with ethical } \\
\text { principles of persuasion.* }\end{array}$ & 4.99 & 1.22 & .12 & .17 & .67 \\
\hline $\begin{array}{l}\text { Ethics education helps students develop } \\
\text { analytical skills.* }\end{array}$ & 5.59 & 1.14 & .16 & .50 & .63 \\
\hline Eigenvalue & & & 7.27 & 1.27 & 1.01 \\
\hline$\%$ of variance explained & & & 48.5 & 8.4 & 6.7 \\
\hline
\end{tabular}

Note. On a scale from 1-7, with 1 indicating Strongly Disagree and 7 indicating Strongly Agree.

Extraction Method: Principal Component Analysis.

Rotation Method: Varimax with Kaizer Normalization.

Factor 1: 7 items, alpha $=.87$. Factor 2: 5 items, alpha $=.82$, Factor 3: 3 items, alpha $=.72$.

$*_{\mathrm{n}}=250$;

$* * \mathrm{n}=249$.

Reversed coding performed for the item, Ethics education does NOT create moral character. 
Multiple regression analysis was performed to investigate the extent to which attitudes toward the value to students of ethics education might be predicted by such variables as gender, academic rank, country of birth, country in which a respondent currently teaches, years of teaching experience, completion of a free-standing ethics course, experience in PR industry, and whether a respondent has taught a separate ethics course (Table 5).

A regression equation was statistically significant $(F(8,170)=1.423, p<.001)$ with $\mathrm{R}^{2}$ of .063. One out of eight variables appeared to be a significant predictor (Table 5). The test showed that the higher the participant's rank, the less favorable attitude toward value to students of ethics education he or she had.

The Pearson correlation coefficient was estimated for the relationship between pairs of variables mentioned above, and a low negative correlation $(r(190)=-.226, p<.01)$ indicated a significant relationship between the rank and the number of years a respondent worked as a public relations practitioner. The higher the rank, the less the participant worked in the public relations industry, or vice versa. 
Table 5. Multiple Regression Analysis Results for "Value to Students of Ethics Education" as the Dependent Variable

\begin{tabular}{llcc}
\hline Variable & Coefficient & Beta & $t$ \\
\hline Gender (1=male) &.-.227 &.-.012 & -.156 \\
Rank (1=instructor) & -1.533 & -.209 & $-2.461^{*}$ \\
Country of birth (1=the US) & .930 & .091 & 1.062 \\
Country in which a respondent & & & \\
teaches (1=the US) & 1.117 & .091 & 1.087 \\
Years as a teacher & .115 & .106 & 1.233 \\
Completion of a separate ethics & & & .748 \\
course (1=completed) & 1.152 & .058 & -1.276 \\
Years of PR practice & -.106 & -.100 & \\
Teaching of a separate & & & -.268 \\
ethics course (1=yes) & -.507 & & \\
Intercept & 70.777 & & \\
\hline
\end{tabular}

Note. *Significant at $p<.001 ; \mathrm{R}^{2}$ is .063 .

\subsubsection{Research Question 3}

RQ 3: What do teachers believe is the place of ethics in the PR curriculum, i.e., ethics should be a free-standing course, taught throughout the curriculum, or some other approach?

Table 6 shows that the majority of participants-186(70\%) - believed that the most valuable approach was ethics instruction incorporated in courses throughout the public relations curriculum. Ethics instruction as a separate public relations ethics course was 
ranked as the most effective form of delivery by 50 respondents $(19 \%)$. Twenty eight participants (11\%) named a separate communication ethics course as the most valuable format of ethics instruction delivery.

Table 6. The Value of Formats of Ethics Instruction Delivery $(n=265)$

Format of delivery

Ranking

1 2 3

1. Ethics instruction incorporated in courses throughout the curriculum $186(70 \%) \quad 43(16 \%) \quad 36(14 \%)$

2. Ethics instruction as

a separate PR ethics course $50(19 \%) \quad 112(42 \%) \quad 103(39 \%)$

3. Ethics instruction as a separate

communication ethics course $28(11 \%)$ $110(41 \%)$ $128(48 \%)$

These data were analyzed using cross-tabulations to inspect levels of statistical significance through application of the Pearson Chi-Square test. The significance level established for all tests was .05. Chi-Square tests examined whether there were associations between participants' perceptions of value of format of ethics instruction delivery and their country of origin and country in which they currently teach. The tests did not reveal significant relationships between the variables. Regardless of the country of origin and country in which respondents currently teach, the participants revealed similar attitudes while ranking formats of ethics delivery. The following Chi-square results were obtained: $\chi^{2}=4.82$ $(d f=6 ; p<.05)$ for Ethics instruction incorporated in courses throughout the curriculum; 
$\chi^{2}=3.75(d f=6 ; p<.05)$ for Ethics instruction as a separate PR ethics course; and $\chi^{2}=5.13$ $(d f=6 ; p<.05)$ for Ethics instruction as a separate communication ethics course.

According to data provided by the participants ( $\mathrm{n}=266), 34$ universities and colleges (13\%) offered a specific course in PR ethics, whereas 126 universities (47\%) had a specific course in media/communication ethics. One hundred and six respondents (40\%) said that their departments did not have specific courses in ethics, and they provided the following reasons for that: 83 out of 106 participants (78\%) explained that ethics is best taught throughout the curriculum, not just in one class, whereas $19(18 \%)$ teachers said that the curriculum cannot include all important courses. Three respondents (3\%) reasoned that ethics are lived, not learned, and 1 participant (1\%) said that no one is qualified to teach an ethics course in his university.

\subsubsection{Research Question 4}

\section{RQ 4: What do teachers believe are the most effective pedagogies in teaching ethics to public relations students?}

To assess public relations instructors' perceptions of the effectiveness of classroom pedagogies, such categories as Very ineffective, Ineffective, and Somewhat ineffective were combined and labeled "Ineffective." Accordingly, such categories as Somewhat effective, Effective, and Very Effective were collapsed and labeled "Effective."

Table 7 shows that the most used pedagogies - teacher lectures, case studies, and group discussion - appeared to be the most effective approaches in teaching ethics, whereas the least effective teaching method seemed to be research papers. 
Table 7. Usage and Effectiveness of Pedagogies in Teaching Ethics

\begin{tabular}{lllllll}
\hline Pedagogies & Have used & $M$ & $S D$ & Ineffective $^{1}$ & Effective $^{2}$ & Rank $^{3}$
\end{tabular}

1. Teacher lectures

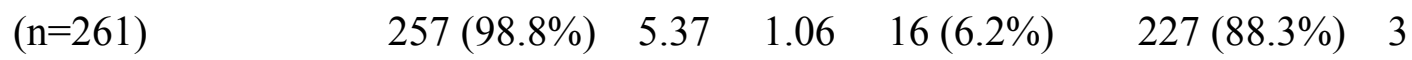

2. Case studies

$\begin{array}{lllllll}(\mathrm{n}=261) & 244(93.5 \%) & 6.32 & 1.01 & 5(2.0 \%) & 236(96.7 \%) & 1\end{array}$

3. Group discussion

$\begin{array}{lllllll}(\mathrm{n}=261) & 243(93.1 \%) & 6.23 & 1.02 & 6(2.5 \%) & 231(95.1 \%) & 2\end{array}$

4. Reading from

trade publications

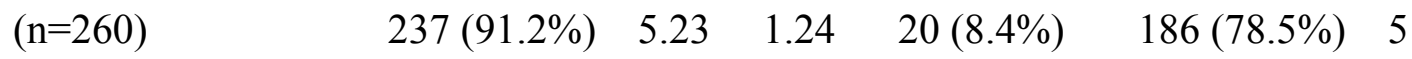

5. Student-led projects

$\begin{array}{lllllll}(\mathrm{n}=260) & 217(83.5 \%) & 5.53 & 1.37 & 19(8.8 \%) & 169(77.9 \%) & 6\end{array}$

6. Guest presentation

$\begin{array}{lllllll}(\mathrm{n}=261) & 216(83.4 \%) & 5.48 & 1.27 & 14(6.5 \%) & 178(82.4 \%) & 4\end{array}$

7. Research papers

$\begin{array}{lllllll}(\mathrm{n}=261) & 212(81.2 \%) & 5.04 & 1.39 & 30(14.2 \%) & 151(71.2 \%) & 8\end{array}$

8. Socratic dialogue

$\begin{array}{lllllll}(\mathrm{n}=261) & 211(80.8 \%) & 5.51 & 1.27 & 13(6.2 \%) & 164(77.7 \%) & 7\end{array}$

Note. ${ }^{1}$ Calculated for "Very ineffective," "Ineffective," and "Somewhat ineffective." ${ }^{2}$ Calculated for "Somewhat effective," "Effective," and "Very effective."

${ }^{3}$ Rank of perceived effectiveness. 
Asked to list any other pedagogies that had been effective for them, study participants mentioned a number of pedagogical methods. Four teachers employed movie/documentary discussions, whereas three respondents used modeling experiments (role playing) in ethics courses. As one respondent said, "I have used role playing activities where students adopt an ethical position and have to act accordingly." Other pedagogies included service-learning activities, conferences, projects with real clients, field trips, and class debates. As one participant wrote, "Media ethics debate (teams debate a case, applying ethical theories, codes, etc.) is helpful."

\subsubsection{Research Question 5}

\section{RQ 5: What do teachers believe are the most effective sources or materials used for teaching ethics to public relations students?}

To examine public relations instructors' beliefs about the effectiveness of sources and materials used in classrooms, such categories as Very ineffective, Ineffective, and Somewhat ineffective were combined and labeled "Ineffective." Accordingly, such categories as Somewhat effective, Effective, and Very Effective were collapsed and labeled "Effective." As in the case of pedagogies, the most used resources in teaching ethics- - textbooks, trade magazine articles, and newspaper or magazine stories - were perceived as the most effective, whereas blogs appeared to be the least important source in teaching ethics to public relations students (Table 8).

Thirty-one participants provided a list of resources that they found to be effective in teaching ethics. Eleven respondents mentioned their own and visiting professionals' experiences on the job, whereas one respondent found it useful to instigate "conversations from the students' experiences." Four teachers said that they used not only textbooks but also 
"PR case studies books" and "Books that are not defined as PR books—-books about unethical business practices, books about international differences in business practices, studying moral codes other than Christian-Judeo models, such as Confucian values that guide professional behavior in East Asia."

Other participants brought up such teaching resources as "cases from local PRSA ethics workshops," "Arthur Page Society case studies competition winners on the website," "student explanation for research projects," and movies.

Table 8. Usage and Effectiveness of Resources in Teaching Ethics

\begin{tabular}{lllllll}
\hline Resources & Have used & $M$ & $S D$ & Ineffective $^{1}$ & Effective $^{2}$ & Rank $^{3}$ \\
\hline 1. Textbook(s) & & & & & & \\
$(\mathrm{n}=256)$ & $253(98.8 \%)$ & 5.08 & 1.30 & $33(7.1 \%)$ & $205(81.0 \%)$ & 2
\end{tabular}

2. Trade magazine

$\operatorname{articles}(\mathrm{n}=256) \quad 257(93.8 \%) \quad 5.09 \quad 1.35 \quad 28(11.7 \%) \quad 182(76.6 \%) \quad 3$

3. Newspaper or

newsmagazine

$\begin{array}{lllllll}\text { stories }(\mathrm{n}=256) & 248(93.5 \%) & 5.64 & 1.35 & 21(8.5 \%) & 212(85.5 \%) & 1\end{array}$

4. Academic journal

$\operatorname{articles}(\mathrm{n}=256) \quad 235(91.8 \%) \quad 4.72 \quad 1.36 \quad 46(19.6 \%) \quad 159(68.3 \%) \quad 6$

5. Internet stories or

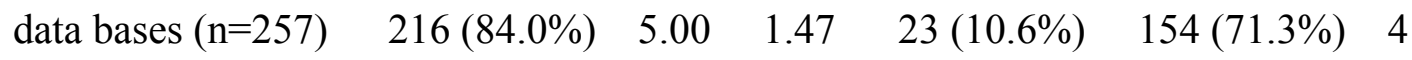

6. Videos $(\mathrm{n}=256) \quad 201(78.5 \%) \quad 5.16 \quad 1.44 \quad 23(11.4 \%) \quad 141(70.1 \%) \quad 5$

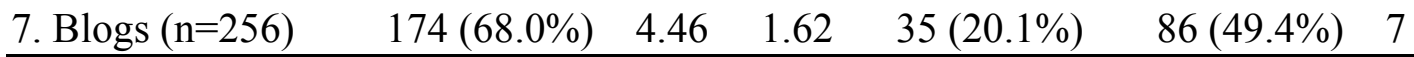
Note. ${ }^{1}$ Calculated for "Very ineffective," "Ineffective," and "Somewhat ineffective." ${ }^{2}$ Calculated for "Somewhat effective," "Effective," and "Very effective." ${ }^{3}$ Rank of perceived effectiveness. 


\subsubsection{Research Question 6}

\section{RQ 6: What are the most effective techniques for evaluation of student learning regarding ethics?}

To assess public relations instructors' perceptions of the effectiveness of techniques used for student evaluation, such categories as Very ineffective, Ineffective, and Somewhat ineffective were combined and labeled "Ineffective." Accordingly, such categories as Somewhat effective, Effective, and Very Effective were collapsed and labeled "Effective." It appeared that there was a discrepancy between the most used and the most effective methods of evaluation of student learning (Table 9). Particularly, although 99 percent of respondents employed written examinations, the effectiveness of this method was ranked as only number five among assessment tools in teaching ethics. Such a tool as individual projects had the third rank on the scale of effectiveness, but its usage was ranked only number five out of six possible categories. Written case studies were rated as the most effective tool in teaching ethics, whereas term papers were perceived as the least effective tool for evaluation of how well public relations students acquire knowledge about professional ethics.

Eighteen respondents identified additional assessment tools that have been effective for them. Seven teachers mentioned different kinds of class discussions. Particularly, one respondent wrote, "Discussion board -supplements class discussion by permitting students to offer views and new ideas on their own time.” Another participant has accessed student learning through "Reviewing current ethical dilemmas in the news and then relating that to a project the students are working on in class."

Four teachers have used such an assessment tool as a short or reaction paper. One respondent wrote, "I have found the best practice is short papers (3-4 pages) where students 
incorporate various models of ethical conduct and evaluate cases based on these frameworks." Other participants mentioned class exercises, homework assignments, and presenting at school conferences as tools to evaluate student learning.

Table 9. Usage and Effectiveness of Assessment Tools in Teaching Ethics

\begin{tabular}{lllllll}
\hline Assessment tools & Have used & $M$ & $S D$ & Ineffective $^{1}$ & Effective $^{2}$ & Rank $^{3}$
\end{tabular}

1. Written

examinations

$(\mathrm{n}=256)$

$233(98.8 \%) \quad 5.32 \quad 1.15 \quad 15(6.4 \%) \quad 194(83.3 \%) \quad 5$

2. Written case

studies $(\mathrm{n}=257)$

$225(87.5 \%) \quad 5.84 \quad 1.11 \quad 10(4.4 \%) \quad 206(91.5 \%) \quad 1$

3. Individual and

panel presentations

$(n=256)$

$222(86.7 \%) \quad 5.80 \quad 1.12 \quad 6(2.7 \%) \quad 199(89.6 \%) \quad 2$

4. Group projects

$(n=256)$

$221(86.3 \%) \quad 5.67 \quad 1.24 \quad 13(5.9 \%) \quad 189(86.4 \%) \quad 4$

5. Individual projects

$(n=257)$

$217(84.4 \%) \quad 5.59 \quad 1.09 \quad 7(3.2 \%) \quad 194(89.4 \%) \quad 3$

6. Term papers

$(n=257)$

$208(80.9 \%) \quad 5.00 \quad 1.35 \quad 24(11.5 \%) \quad 150(72.8 \%) \quad 6$

Note. ${ }^{1}$ Calculated for "Very ineffective," "Ineffective," and "Somewhat ineffective." ${ }^{2}$ Calculated for "Somewhat effective," "Effective," and "Very effective."

${ }^{3}$ Rank of perceived effectiveness. 


\subsection{Interview Findings}

The seventh research question examined similarities and differences in teaching philosophies and practices of American and European teachers. All participants agreed that ethics education is essential for public relations students. The 52 teachers provided diverse explanations of why ethics needs to be taught to future professionals, and educators often mentioned more than one reason. Qualitative analysis (Lincoln \& Guba, 1985) suggested that there were a number of themes associated with the importance of ethics instruction at the university and college level.

\subsubsection{Proposition I. American and European public relations educators think that} ethics are important for education, but they view this importance in different ways.

The theme of awareness appeared to be the most frequently mentioned by U.S. educators. However, there was not a single interpretation of the meaning of this notion.

\subsubsection{1. $\quad$ Awareness as preparedness to deal with ethical dilemmas.}

One-third of U.S. participants explained that ethics education is vital because "it creates awareness that the professional world is saturated with ethical dilemmas" and this is why it is so important to "give an understanding of what is ethical and what is not." As one female educator said, “I don't think that PR students understand what they will be confronting. It's not a golden lovely world out there where everybody plays fair." In her opinion, educators should prepare students to face not only "a big hairy incident" akin to Enron, but also to deal with "little things" that might not appear as unethical at the first glance (a "hyperbolic word used in the press-release" or a "company's logo used in the proposal without client's permission"). 
Two U.S. participants emphasized that PR graduates should be aware that they would be expected to advise management on key decisions in ethically challenging situations.

4.3.1.2. $\quad$ Awareness as the responsibility to use knowledge in the ethical way.

Seven U.S. participants thought that ethics instruction is an essential part of PR education because it creates awareness about the morality of knowledge, or the necessity to be responsible for "what we do with what we know." One participant noted,

The core reason for why we teach ethics is that communication students need to know that by learning new expertise — how to persuade and influence people - they have a moral obligation not to use it in a way that would be harmful to people.

Another respondent echoed by this: "By the very nature of the profession, we are powerful and influential in society. We have to be aware of that and aware about how our actions do impact society."

\subsubsection{Awareness as anduction into the profession.}

One-half of interviewed American educators perceived ethics instruction as being "best suited" to create awareness that, as one senior teacher said, "Education is not about knowledge and skills only but also about a basic subscription to ethical values of the occupation." The fact that public relations is an inherently ethical occupation that has moral obligations to society was articulated by another participant:

The idea is being ethical is essential to the stature of public relations as a professional activity. And by definition to be professional, the activity must uphold some kind of public interest which is what is embedded in your code of ethics. So it [ethics education] is absolutely essential and our job as educators to communicate values to our students. 
Overall, the majority of U.S. educators underlined the importance of ethics education as education that contributes to the improvement of the profession and society: Commitment to professional values, moral obligations to society to behave ethically, and the ability to perform a counseling function in a complicated ethical situation.

European educators appeared to have a more homogenous opinion about the importance of ethics education. They were united in their perception of the essentiality of ethics education as a means to make students "be aware of themselves, their identities and their personal values;" as education that encourages them to think that "every decision that they make in lives has an ethical aspect." In other words, the majority of European participants emphasized the importance of ethics education as the process of character development. A world-known European educator and scholar said:

There is no a causal relationship between an ethics course and making good choices on the job. But definitely, ethics education helps students become more critical and reflective, and more reflective people will make more thoughtful decisions.

"Reflectivity" appeared to be a key word in European educators' discussion of ethics education. One of the teachers explained that "reflecting means comparing your understanding and practice (if you had worked before you entered the university) before and after a theory was introduced." Besides that, the teacher thought that for students, it is also very important to be exposed to different opinions and compare your understanding of ethical dilemmas with understandings of classmates. He added,

I want students to say, "When I face with an ethical dilemma, I understand that I can look at it from more than one point of view, I can analyze it using different theories. But at the end, I need to make a judgment, and this is my judgment, and my values 
will make me behave this way or that way." I want my students to understand that an ethical choice is a self-conscious choice based on reflective thinking.

While American educators emphasized their commitment to the public relations industry, European teachers underlined their universities' disengagement from the industry. A young female professor who teaches a PR course at a leading European university said:

We incorporate ethics in courses throughout the curriculum, not because we are afraid that students after graduation would do unethical things. We integrate ethics in the discussion of the theory of science. We talk about ethics not from an applied perspective but from a science perspective.

However, the issue of "loose coupling," or a lack of cohesion between the European system of higher education and PR industry might not be so simple and straightforward as it might appear at the first glance. As a doctoral candidate (a teaching assistant) said, Our tradition of higher education is not to train people for a certain job. Officially, we don't prepare students to be excellent PR managers or journalists. However, it's a complicated issue. Only 3 percent of students are going to have careers as researchers, and more than 90 percent of graduates will have jobs in communication. Of course, I teach them with this fact in my mind. But at the same time, I don't hand them out strategies and tactics like "how to make your business grow." In my opinion, this is not what the university is about.

A senior professor said that they have "some courses on skills but they are not our focus." In her opinion, the goal of the university is to give "reflective knowledge, not only applied knowledge.” The colleague of this professor provided the rationale for this goal by saying that knowledge is outdated very fast, and this is why the university should concentrate 
on developing the analytical mind. In her opinion, it is hardly possible to help students become "skeptical and critical about social reality" if PR courses are taught as "you teach a PR Campaigns course - by providing students with a check list 'what you need to do to make your campaign successful.”

American scholars (Elliott, 2007) are concerned that university textbooks that address practical ethics do not do so in a satisfactory way: They introduce classical moral philosophies only briefly and, thus, reduce them to slogans. A few European scholars brought up this issue in their interviews. A professor, who teaches a media ethics course in a European university, said that he had a chance to look at an American PR textbook. He found it to resemble a "school book or recipe book." Such a textbook might fit the "American functionalist environment," but it is questionable if this text can be used in Europe. The teacher said that he assigns undergraduate students to read "hundreds of pages of original texts every week" because "students need to learn by themselves" instead of "being supplied with recipes about how to act." In this regard, an American educator (Duffy, 2000) argued that "Textbooks must not only prepare students in practical matters, such as how to plan a public relations campaign, but in ideological matters" (p. 311).

Another European teacher appeared to have the same teaching philosophy of independent study ("the essence of university life") as his colleague who teaches the media ethics course. He also assigns his undergraduates to read original texts, and these manuscripts come from major academic communication journals. Asked about whether students perceive such assignments are being too difficult and time consuming, the teacher said that the students "complain but they still do then" because they understand that they are expected to read academic texts in the university. 


\subsubsection{Proposition II. American and European public relations educators' practices reflect different teaching philosophies.}

The realism/idealism dichotomy might be a rather questionable concept in both philosophical and common senses (Pierce, 2007). However, some phenomena are difficult to describe without these two categories. Keeping in mind limitations of this dichotomy, this study nevertheless appeals to the concepts of realism and idealism to define some differences in American and European teachers' philosophies.

Presumably, the fact that participants in the U.S. and Europe teach the same expertise contributes to developing similar thoughts and beliefs. As an example, the statement made by a well-known U.S. ethicist, "I want students to think not so much about what they should do but more about why they should do the right things," was echoed by many American and European educators.

However, a notable difference appeared in the overall direction and tone of American and European monologues. The majority of U.S. educators' indicated a special role of public relations professionals as contributors to an ethical climate of society and exhibited a positive, "can do" attitude while talking about a possible impact of ethics courses. This is reflected in the following inspirational rhetoric of one U.S. educator:

A larger message that I send to them [students] is that we are responsible, we are covenant of the earth, and if we don't take care of the earth, if we don't care of the people, it's no purpose of us. We are stewards of the earth. And I expect PR to be used in this manner.

The majority of American educators emphasized that their goal is to give their students an understanding that public relations is not isolated from the community in which PR operates, and this is why public relations professionals serve interests larger than those of 
the organization that hired them. As one senior educator said, "The organizations' interests are never devoid from the interests of other people in society."

Another senior teacher and scholar linked the profession, ethics, and democracy: We have a role in society; we have a role in a democracy that we have to perform, and there are certain things that we can't do because they are unethical from the professional point of view.

Addressing the issue of PR professionalism and ethical behavior, an American educator linked professionalism and ethics by saying, "If you want to be a professional, do the right things because the difference between PR professionals and those who are selling their time to a higher bidder is expertise and ethical standards."

Meanwhile, European educators were rather careful in their opinions about a special ethical role of PR professionals in society. A distinct theme of the majority of European participants was a clash between PR theory and PR reality. As one teacher said, "The main goal is to give students realization that at the theoretical level, things might look simple, whereas in the reality, things are much more complicated."

According to European educators' perceptions, generally, in the real PR practice, an individual is constrained by "too many factors and too many actors." One teacher writes down theoretical statements of PR scholars and quotes of PR practitioners on a blackboard, inviting students to discuss differences between "normative and real PR."

Another teacher, a former PR manager for a non-governmental organization, said that to perform well in the professional life, students need "to understand pressures and constraints" of the reality before they enter the profession, and this is why teachers of his department constantly address "controversies of PR practice." 
Across the three countries - the United Kingdom, the Netherlands, and Germanyeducators revealed similar philosophies when addressing a discrepancy between theory and practice. As one teacher, a former PR practitioner said, "We encourage students to hear about difficult issues in PR and about criticism of PR work by critics and journalists; sometimes they are very rude. We encourage them to write essays about it and make presentations." Students of this teacher monitor the $P R$ Watch website and constantly meet with practitioners and critics during guest lectures.

Another teacher, talking about the Excellence Theory (Grunig, 1992), called it a "PR professional $20^{\text {th }}$ century ideal model of relationships." In his opinion, these relationships are ideal because they are described as "reciprocal and are not shaped by imbalances in power." Meanwhile, in his opinion, an appropriate framework of thinking should be, "What would be realistic expectations against ideal?" The teacher added that a "discussion about approximation to ideal" is needed if teachers want to shape a realistic understanding of PR practice among students. In his opinion, American higher education is closely tied to the industry that leads to the practice of a "narrow vocational training" in communication departments. Meanwhile, his department "stepped over making it [education] not merely vocational training" but the education that meets requirements of academic professions. Importantly, the department remains "open for standards set by both the industry and vocationalism," but these standards do not override an academic principle of liberating minds.

A European teacher whose area of expertise is political communication said that while visiting the U.S., she witnessed a negative PR campaign, which focused more on diminishing the image of a rival rather than improving the image of a candidate for whom a 
group of PR practitioners worked. The teacher commented on it by saying, "It might be all right from a professional point of view, but it's questionable from the ethical point of view." This idea—-PR" does not automatically mean "ethicality"—was well pronounced in a number of European monologues.

Another teacher noted that because public relations has such a strong association with spin, his academic duty is to examine manipulative PR practices. The teacher asked, "Is it ethical to pretend that spinning doesn't happen?" And then he concluded, "It would diminish PR education if we didn't talk about embarrassing issues."

Coming back to American interview participants, it is important to emphasize that none of the American participants said that they avoid discussion of "the dark underbelly of the PR industry" (Burton, 2007). In this regard, one American teacher remarked that "ethics is a luxury" these days, whereas her colleague said, "Reputation of PR is as low as it could go." However, it did not appear that in their classes, U.S. educators pay the same amount of attention to negative PR practices as European teachers seem to do. As an American PR instructor said, "You can learn better if you see what other people do is right." Another American teacher provided a further explanation for why positive examples should be included in teaching discourse. He said that when students go to the profession, "they will observe others and have both positive and negative exemplars." A possible danger is that PR graduates might have only negative exemplars, and "they will think that this is how the industry, the profession operates." This is why by "sensitizing students to ethical situations and even giving them a little bit of moralizing information," public relations teachers "equip students better to deal with ethical problems when they go to the profession." Another U.S. educator was concerned with the fact that students "have a lot of models for amoral points of 
view in terms of professional lives and relationships." In this sense, ethics education is crucial since it provides students with other—ethical models—-for their professional lives.

To summarize, although both groups of the participants-American and Europeanrealize that public relations practice is far away from being consistently ethical, they take different paths to prepare students to deal with questionable ways of doing PR. While European teachers ("realists") spotlight the dark side, American educators ("idealists") emphasize the bright side. It is important to clarify that these paths do not run in opposite directions; teachers do not bring up exemplars that are either totally negative or purely positive. It is rather a combination of both. If the PR practice can be imagined as a continuum that runs from white to black, a large grey segment would appear in the middle, symbolizing the complexity of labor of "developing and nurturing relationships" (Berger, Reber, \& Heyman, 2007). This complexity was acknowledged by all participants in this study regardless of the country in which they teach.

\subsubsection{Proposition III. European participants think that there are apparent} differences in ethics education in the U.S. and Europe.

European teachers did not believe that American PR is more ethical than European PR, or that bosses in the U.S. put less "unethical" pressure on PR managers than bosses in Europe do. Nevertheless, according to European educators, American PR educators tend to create a rather normative or ideal image of the profession, whereas Europeans tend to provide their students with a realistic description of PR practice.

Attempting to explain such a discrepancy within the Western academic world, European educators brought up a number of factors. First, they believed that culture (e.g., positive "can do" attitude) influences teaching philosophies and practices of U.S. educators.

As a European teacher said, "Probably, American teachers think that they have more 
influence on students than European teachers do." And her colleague believed that whether in everyday life or academia, Europeans "are more skeptical, cynical, and realistic," compared to Americans.

Second, European participants, who are familiar with American PR scholarship, believed that the scholarship tends to emphasize and call for normative PR rather than to explore its real practice. As a result, American teachers, who are scholars as well, are inclined to concentrate students' attention on ideal rather than on existing models.

In this regard, L'Etang (2008) argued the dominant paradigm in PR has been criticized by a number of non-U.S. scholars for its focus on "functional issues such as effectiveness, excellence, methods, evaluation, professionalism, PR role and status" (p. 10). Meanwhile, functionalism presumes a consensus which is hardly reachable due to the fact that different individuals have different views about what is functional and what is dysfunctional (L'Etang, 2008). In her opinion, “Although many academics seek to 'build PR theory' one might wish to question the existence of such. The very term 'PR theory' almost seems to imply there could or should be a single framework" (p. 13).

L'Etang (2008) argued that while the dominant paradigm encompasses such perspectives as feminist, rhetorical and relational, it failed to incorporate other critical perspectives. Particularly, the dominant paradigm is based on positivist approaches and quantitative methods, whereas critical and cultural scholars [post-positivists, or those who were "othered by the dominant paradigm" (p. 253)] value qualitative methods of inquiry. A leitmotiv of the resistance movement that emerged against the dominant paradigm in the middle of the 1990s (L'Etang, 2008) was clearly heard in monologues of European educators, who insisted on their own way of conceptualizing and practicing PR. 
Third, the majority of European participants pointed out that American universities that educate PR professionals are closely tied to the PR industry. In L'Etang's (2008) words, "A key assumption of the dominant paradigm seems to be that academic work should contribute directly to practice” (p. 252). In European participants' opinion, such a dependency potentially puts a lot of pressure on PR educators who might feel obligated to be "cheerleaders or apologists or both for the profession.” Meanwhile, European universities that educate future PR practitioners are "full universities, not applied science universities," meaning that they are responsible for the "general liberal education" that seems to be disengaged from industries.

In this regard, Nessmann (1995) argued that PR programs in the U.S. and Europe differ significantly in their structure and nature. The majority of European universities do not offer a degree specifically in public relations and emphasize a broader communication degree, whereas more than 160 American universities have a PR degree program or at least a sequence. Moreover, Hazleton and Cutbirth cited in Nessmann (1995) noted that European universities focus on theory more than on practical skills, whereas American universities are preoccupied with job related training, since U.S. educators want their students to compete effectively on the job market.

According to the majority of European teachers, the fact that universities maintain their right to be neutral toward the PR industry has its implication for ethics education: "It's more about teaching critical thinking than training to solve work problems." This remark of a European teacher was a leitmotiv of interviews with European communication educators.

Fourth, one-third of Europeans linked the religiosity of American society and "undivided personal and professional identity." This tie, according to one participant, "makes 
Americans think that they should confront what they believe is not right, even if they might sacrifice a job in this struggle.” Another teacher said that the missionary culture makes teachers inspire students "to go and change the world," and this rhetoric is understood by the students who have been part of the missionary culture from the early age.

Fifth, the majority of European teachers believed that because their universities have a much more diverse undergraduate population than American universities, the teachers, as one educator said, "cannot be ethical dictators who try to impose some rigid ethical standards on people who come from very different assumptions and different experiences in the world." In his opinion,

Students should emerge from here being critical and reflective, showing awareness of issues, showing the ability to appreciate both sides of a question before drawing the conclusion, and not trying to adopt some unreal pure PR ethics which doesn't recognize that PR is based on the real working world.

While spotlighting differences in American and European PR education and analyzing their causes, European teachers emphasized that in the same manner as PR practices worldwide cannot be treated as "right or wrong," PR education cannot be judged from an ethnocentric point of view. As one European teacher said, "PR is a kind of mirror to society. PR people are social beings and what they do reflects society.” Accordingly, PR education in general and teaching approaches in particular are social and culturally bound phenomena, and they should be analyzed taking in consideration a multi-level societal context (university, region, country, and continent). 


\subsubsection{Proposition IV: American and European educators appear to be similar in their perceptions of challenges in teaching ethics.}

Difficulties associated with teaching ethics to public relations students originate from multiple sources at different levels - individual, professional, and societal. These challenges include but are not limited to an increased student religiosity, vaguely defined professional codes of ethics, relations with journalists, and overall societal environment.

\subsubsection{Religiosity.}

A few U.S. and European teachers addressed the issue of student religiosity which is defined as a "person's degree of adherence to the beliefs, doctrines, and practices of a particular religion" (Dube \& Wingfield, 2008, p. 503). One professor said that he found that "religious absolutism often can be quite dysfunctional in terms of public relations work." In his opinion, when students appeal exclusively to the Bible, such a practice tends to "shortcircuit any kind of individual critical thinking."

Two other American educators noted that quite often, their PR students confuse ethics with religion. However, as a response to teacher's attempt to show that "religiosity" does not automatically mean "ethicality," students might complain that "the teacher challenges my religious beliefs." The two respondents admitted that they are not ready to deal with challenges imposed by student religiosity, and they think the U.S. educational community should discuss this issue to find meaningful ways to respond to manifestations of religious indoctrination in classroom.

European educators were divided in their views of whether religiosity is a difficult issue to deal in ethics class. Some of them saw it as a challenge- "to allow students freedom of speech without something which is damaging to beliefs of religious students." In that particular university, the majority of communication students represented Christian and 
Muslim believers, and their debates on religious topics imposed a challenge for a teacher who had to follow the policy of a secular university and did not allow turning the class in a religious battleground. In his opinion, in that university ethics comes into play in terms of respecting differences in an international classroom.

Another European teacher said that the fact that his students represent a number of religious denominations helps him to address ethical issues in communication: "My mission is to draw on this diversity." As an example, while covering the topic of corporate social responsibility (CSR), the teacher asked students from Bangladesh and Pakistan if they were willing to comment on what CSR is from an Islamic point of view:

They said that companies pay automatically—a percentage of their profit is deducted to the community fund. It's the law because Mohammed said so. This example illustrated how Islamic principles are infused in countries' financial system. In another class I was talking about a free choice in developing an organizational strategy. Islamic students said, "It's an Allah choice."

In this teacher's opinion, by being exposed to a variety of opinions and learning about how the world differs in problem-solving approaches, students gain better understanding of themselves by uncovering their own prejudices and respect opinions and lifestyles that are different from their own.

Apparently, the process of self-disclosure is a difficult one. As one American teacher said, "It takes a while to get students comfortable enough to discuss their concerns in class." The reason is that students think that they need to be politically correct and "do and see things" in a socially expectable way. 
A European teacher said that he treats his "Understanding Public Relations" course as a "very international course" in which ideas from any country are welcomed. In his view, an opportunity to freely express a personal view is the practice that distinguishes a university course from a training course.

Overall, while American PR educators are concerned with the internationalization of the PR practice, European teachers are in the process of finding ways to manage diversity within their communication classes.

\subsubsection{Professional ethics code.}

While talking about the necessity to evaluate student learning in ethics class, one American professor remarked that educators cannot be successful in this task since there is "no way to evaluate the success in something that hasn't been described yet," meaning that the profession has not articulated its ethical standards. He said:

Public Relations Society's ethical standards are basically about trade protection:

“don't break the law," and “don't steal somebody else's clients." As far as any kind of substantive ethical standards for the profession, it's all watered down and it's voluntary.

Moreover, in this teacher's opinion, the profession does not seem to be engaged in active debates about what these standards should be. So far, the profession has been restraining the trade, and "this is not ethics, it is business arrangement." In this regard, Benson (2008) argued that academics should "distance themselves from their too-close historic association with business" (p. 20) and develop more close ties with nongovernmental organizations. 


\subsubsection{Teaching controversy.}

Two American participants pointed out that an ethical controversy is embedded in the very process of teaching PR majors: "We teach students to write a letter to the editor and sign someone's name. Is it ethical?"

A European educator said that PR students are taught to get their messages through in an editorial content or journalistic stories without really saying, "I represent this company." In her opinion, "It is quite similar to brand placement." Yet, the teacher said that she would not take a stand by saying that it is completely unethical: "It depends on not so much PR people's perceptions, but the audience' perception of what is ethical and what is not." This statement might have an implication for teaching ethics to PR majors: While making a decision about a case in which ethics is involved, practitioners should take into consideration not only their personal values and professional codes, but also know the audience's attitude toward the issue. "Who decides what is ethical?" is a crucial question that indicates the complexity of decision making process in public relations.

\subsubsection{4. $\quad P R$ ethics in the international setting.}

At least a half of participants addressed challenges in teaching ethics imposed by the era of globalization. One U.S. female professor said that in her class, she focuses on case studies because "many of them are international, and the purpose of that is to show how complex ethical decisions can be." The teacher said that for her, ethics exists not only at the theoretical impersonal level: "Ethics is in my office when international students come to cry on my shoulder about American bombing of a foreign country."

Another American participant believed that some ethical principles are easy to students to understand. For example, "Do not bribe' is easy." However, when this principle is 
applied abroad, it becomes much more complicated. As the teacher said, "What if you are in Turkey and need to place something in media? You have to pay a journalist, and it's embedded in their culture and this is how they do journalism in Turkey." Another participant echoed this statement, saying: "What is baksheesh? Is it social respect or a criminal act?" Apparently, the answer depends on the country in which baksheesh (a gratuity or alms) is being offered. In the U.S., it is an inappropriate act akin to bribery, whereas in some Asian countries, baksheesh is part of culture (Curtin \& Gaither, 2007).

Although a senior educator believed that his goal is "to get students to recognize ethical issues in a real world situation," meaning to help them see how general principles apply for specific situations, the teacher admitted that he could not say with a certainty what ethical standards for the practice of PR are applicable in the global scale.

A European teacher, an author of a few books about public relations, said that while a "set of techniques used by PR practitioners are very similar around the world," PR professionals use them in a variety of ways, "depending on the nature of the media, the nature of society, and people's values." In his opinion, although the UK is much more similar to the U.S. than many other European countries, nevertheless, British PR practice is quite different from American PR.

Another European educator believed that American and European educators might have different opinions about how to teach ethics to PR majors because of significant cultural differences. He said that while "American culture encourages earning a lot of money and CEO's million dollars salaries are acceptable in the U.S., European culture encourages to be "normal" [to be satisfied with a modest income]. We don't think that a million dollars salary is ethical." 


\subsubsection{Problem of evaluation of student learning.}

American and European educators were united in their opinion that evaluation of student learning might be the most difficult part of the teaching process. As one U.S. teacher said, "We test, we don't evaluate." Indeed, many participants in this study emphasized that tests - a multiple choice or even open-ended questions — cannot be taken as a reliable measure of student effective learning in part of predicting their behaviors. As one European educator said, "You can assess the awareness of ethical dilemmas and understanding of theoretical frameworks but in part of choices that they [students] might make after graduation... It's beyond of my control!" Another participant echoed, "You can make students learn but you can't make them behave."

At the same time, the majority of educators believed that "continuous exposure to ethics leads to more thoughtful behavior," and they referred to studies that examined perceptions of ethics courses by university graduates. As a European teacher said, "We ask them [students] not for knowledge only, but also for an opinion that indicates whether students are growing in their perceptions of ethical issues."

The majority of participants recognized the need for more subtle and sophisticated methods of assessing student learning than "in-class tests/exams." Among methods mentioned by the participants were: Written essays, student presentations, class discussions, reflective journals, and informal observations and meetings. An American teacher said that one informal meeting helped her realize that a student, who "performed very well in class while recognizing ethical dilemmas in scenarios, did not apply ethical theories for herself." The teacher said that the student wanted to mention in her resume the fact of conducting research. The teacher asked for details, and the student answered that she wrote research papers for money. It appeared, according to the teacher, the student thought about herself as a 
"good businesswoman," and did not see anything wrong in being paid for research papers.

The teacher concluded: "The only way to know if you sparked, launched, cultivated, nurtured ethical thought and behavior is seeing it over time."

\subsubsection{Journalism vs. Public Relations, or Who is responsible for a bad PR image?}

Regardless of the country in which they teach, participants were concerned with tension that exists between journalism and public relations professions. A world-known American PR educator made it clear that this situation negatively affects the educational process:

I am not convinced and never will be convinced that journalists are inherently more ethical people than public relations people are. But journalists love to feel it. Law and ethics is often taught by a journalism faculty member, and PR students come out feeling bad about themselves because PR people are characterized as liars and journalists are characterized as heroes of society.

A European educator said that in her country, if someone wants to offend a journalist, he or she needs to call him or her a "PR person." Another European teacher said that the image of PR is worse than its practice, and a "break through" seems impossible since journalists are attuned to bad PR practices and ignore positive acts.

A European teacher whose research focused on relations between journalists and PR managers found that journalists expect PR people to be advocates for their companies and do not expect them to reveal "the whole truth" in a testimonial manner, because journalists want to "get easy to digest, straightforward information," and they do not want to "complicate things."

While a number of participants believed that journalists contributed to creating a negative image of public relations, a European expert in organizational communication 
believed that this "unwanted" image was built in the 1970-1980 by American professionals themselves. In his opinion, in that time PR people "tried to influence public opinion too heavily." Later on, "they learned from the science that PR is limited in its ability to influence people's mind." However, there are still a lot of efforts to "green-wash a questionable image." This teacher is used to discussing "window-dressing" practices with his students. As an example, he asked them to think about "why an American fast food company supports sports?" Students saw elements of "green-washing" in the company's efforts, but in general, they agreed that helping athletes is better than "doing nothing," meaning not trying to balance harm caused by unhealthy food.

Another European teacher said that ordinary people believe that "PR people are dishonest and journalists are honest, but they don't know how much newspaper information comes from press-releases prepared by PR practitioners.” As an example, this teacher offered his students to discuss a "white powder case." This event happened in a European city. One day, a large city territory was covered by a white powder, but media labeled it a "light grey powder." The teacher presumed that PR managers of the plant that was responsible for the eruption of the white substance, aimed to avoid association with anthrax. However, instead of handing his conclusion to students, the teacher walked them through the process of decisionmaking, asking them if they were PR managers and journalists, what would they do in such a situation? Would they call the substance a "white powder" and possibly scare the population? Or would they "stretch the truth" by calling it a "light grey powder"? The teacher said that such "a small thing was an eye-opening experience" for his students, a sort of introduction to the topic of purposeful frames in PR and journalism—frames that might be the result of a collaborative decision of representatives of both professions. 
A European participant who teaches PR and journalism students as a adjunct professor while working full time as a television reporter, noted that the recent tendency of employers to pay less and make journalists work more negatively affects their relationships with PR practitioners. He said that in the 1990s, he used to sit with PR managers and talk through details of the story, and PR people always appreciated such attention. Now he "shoots and runs" to get the story to the air. He said that a leitmotiv of his lectures is that good PR managers are open and truthful, and if some reason they cannot provide journalists with accurate information, they would say, "Sorry, I cannot comment on this," instead of misleading them with "fluffy words."

Anecdotal data show that PR researchers' interest in investigating corporate social responsibility (CSR) in various organizational settings is growing every year. Meanwhile, it appeared that CSR might be perceived as an oppositional practice to public relations. In one European teacher's opinion, PR might be seen as a kind of semi-legal secret activity_-“doing and looking back," meaning "if we get away with it, that's great," whereas CSR is about avoiding doing unethical things not because of the fear of disclose but because "it's fundamentally wrong to do, it contradicts our values." The existence of this frame-CSR is oppositional to PR — should be taken into consideration by PR teachers whose goal, among many others, is to prepare graduates to advocate for the profession in an argumentative way.

\subsubsection{Quit or comply?}

The issue of how PR graduates should react if management wants them to engage in unethical behavior appeared to be very important for participants in this study. In this regard, an American educator said that PR graduates' first ethical choice happens when they choose 
for whom to work. Another teacher said that an ethical choice of PR practitioners would be "to help organizations stop doing unethical things."

However, there was a disagreement about whether a PR graduate should confront management if the boss forces the PR person to act unethically. Approximately one-third of American educators believed in a "quit-job" approach. One female educator said that she advises her students to have a six-month salary put aside to walk away from the organization any time. In this regard, one European teacher said that if PR graduates would leave their job every time they want to avoid an unethical situation, "their careers would be pretty short." Another American participant said that she recommends to her students to start looking for another job immediately after they suspect that the company tolerates dishonest behavior, but quit the job only after they find another one.

Five American educators believed that PR graduates should become "educational" while trying to convince the boss to avoid an unethical path. As one American teacher said, "Ethics education helps students understand that they are not powerless," meaning that they have tools to deal with ethical dilemmas. As this educator explained, instead of slamming the door and quitting the job, the PR professional should "do research and show what happened to people who followed this [unethical] way."

An American teacher said that he constantly emphasizes to his present and former students that as PR practitioners, they are not alone while facing an ethical dilemma: "One of the most important sources of your decision making is your network. You can call anybody up, and without even being totally specific, you can explain what is going on and ask them what they would do and why." As an international PR practitioner in the past, this educator used this approach in his practice. 
One American teacher said that often, a PR practitioner's willingness to stand up for his or her beliefs helps prevent questionable campaigns. As an example, this teacher told a story of her former student who worked as a PR manager for an educational institution only six months when a tragedy happened: a few students died in a car incident. The supervisor of this manager wanted her to use this case to publicize the institution. Though the manager realized that she could have been fired, she still refused to implement such a campaign and convinced the boss to withdraw his decision.

A European teacher, who combines teaching and working as a journalist, said that in some situations, a PR person does not have other choices except to quit. He brought an example from his practice that he shares with his students. A PR manager of a large corporation was respected by journalists for his honesty and expertise. Yet, one day he disseminated information that turned out to be false. The PR manager resigned from his job after he realized that he was deceived by management that provided him with false information.

A common theme of the majority of responses was that while PR managers should consider an option of compromises, they should know "where to draw the line." As a PR instructor said, "When you find yourself in such [problematic] situation, you try your best using your argumentative skills, your best ability to persuade your boss not to act unethically." However, if "no matter what you said, decisions are made... There is always a job."

4.3.5. Proposition V: Participants believe that the best method to teach ethics is to combine a few approaches.

The majority of participants said that there is no a single best approach in teaching ethics to undergraduate students. One participant summarized the responses by saying that 
the best method is a mix of approaches. In his opinion, the key to effective student learning is to make ethics instruction "real and relevant" by employing, first, cases from the news that have a "local angle" that "makes students be interested" in the cases and, second, "talk through ethical scenarios."

Participants in this study outlined a number of approaches in teaching ethics that certainly reflect their teaching philosophies.

\subsubsection{Keeping journals.}

An American senior educator said that "reflective management is the essence of public relations." Ideally, the ability to reflect on professional issues should be cultivated in college. In this regard, an American participant shared his experience in teaching PR students:

In my class, students kept journals, describing their experiences, and at the end of the course one common thing went out — now they recognize ethical dilemmas, now they are looking at their lives in different way. What happened is that they recognized humanity. They began to see that they are not just PR practitioners, they are still human. And that humanity demands of them certain responsibility: "I must approach my practice in a way that I can justify it as the right way." Studying ethics theories allows them to see certain ways to make decisions and then begin to look at their own decisions.

\subsubsection{Shadowing professionals.}

Another approach to better familiarize students with their future occupation was articulated by an American teacher:

I found a good exercise - to go to do interview with professionals. Ask them a set of questions about if the practitioners had ethical dilemmas and how they resolve them. 
Then students write an evaluation of both the situation and the professional, whether it was done well or they would do it differently.

\subsubsection{Writing a moral code.}

An assignment to write a personal moral code appeared to be a creative and meaningful way to help students articulate their personal values and professional intentions. One American educator said that her students write a personal professional ethics code that becomes part of a portfolio. First, the teacher advises her students to observe potential employer's reaction on the code while he or she goes through the portfolio. If the employer stopped and paid attention to the code, it might be a good sign — - he or she cares about ethics. If the code did not draw attention of the employer, it might be an alarming signal. Second, the teacher advises her graduates to hang their ethics codes on the office wall to make it public. In this case, if the boss wants a PR practitioner to do something that violate ethics, the practitioner can always say, "Wait a minute! It was in my portfolio when you hired me; you knew that it was my consideration. And many ways, it can be considered a contractual obligation."

Another teacher, emphasizing the importance of an assignment to write a personal ethics code, said:

One student emailed me years after graduation, saying, "I just started reading my own moral code. I want to tell thank you for guiding me along through this process, and I am confident to tell you that in most part, I've been living up to my code."

In this regard, communication teachers appeared to believe in the ethical capacity of their students, or their abilities to comprehend ethics issues. One American teacher said, "In essence, all of them [students] have [ethical] capacity. The question is how much knowledge, 
practice and reasoning abilities they have," meaning that good intentions should be backed up with experience, self-confidence, and critical thinking. Another educator remarked that unethical people do not choose the PR profession - unethical people might gravitate to professions that provide a chance to earn millions of dollars.

\subsubsection{Proposition VI: The majority of American and European educators think that the best format of ethics instruction delivery is to combine a free-standing course with ethics discussions in every course.}

Participants appeared to have different opinions on what format of ethics

instruction - a free-standing course or ethics incorporated throughout the curriculum —is the best way to insure student effective learning. One participant's opinion summarized views of the group of American and European teachers (24 participants) who believe in the approach of "ethics throughout the curriculum:"

Ethics needs to be taught as an essential part of every course because every choice that is made — whether a strategic planning choice or wording choice—-has an ethical component to it. Any time when you make ethical choices that can affect others you are making ethical judgments, and you have to be mindful of applications of these ethical judgments.

A group of 9 participants disagreed by saying that PR education should include "a stand alone PR ethics course, maybe media ethics course, certainly, separate from law." In one teacher's opinion, "Ethics needs to be slow cooked, in the sense that it needs to be integrated in everything we do, as oppose to garnish we sprinkle on the top at the end of the course, "By the way, everything that PR professionals do should be ethical." This opinion represents a number of participants who think that "ethics deserves to be a separate capstone course." 
The majority of respondents believed that the most effective way is to have a freestanding course and use ethics discussion in every course in every class meeting.

This study showed that the balance of theory and practice was a challenging endeavor for American PR educators. As one teacher said,

If you go too philosophical, you lose them [students]. If you go absolutely practical, they don't understand how to apply the situations in specifics. Try to find a balance where they can reason through abstractly but still see practical application. That's a hard work.

Overall, the analysis of qualitative interviews showed that American and European teaching philosophies and practices are overlapping, and differences between them are explained by larger differences (e.g., societal and university culture and history). While U.S. educators emphasized the necessity to study norms and values of the profession, European educators focused on studying classical theories and articulating student personal values, or encouraging them to develop their “own personal take on public relations" (L'Etang, 2008). As a response to European convergence, a doctrine of a European Space for Higher Education was developed in Bologna, Italy, in 1999 (Seccion Especial, 2004). When it is fully implemented in 2010 , the doctrine will result in a borderless system of higher education in Europe (e.g., unified credits transfer system, the ability of students and professors move across countries, and internationally compatible degrees). The Bologna process reflects concern of the high level educational managers that European universities are "unemployment factories" and their desire to modernize the process of teaching to meet requirements of labor market (Seccion Especial, 2004). 
Participants in this study represented universities that have already introduced a new structure of university courses - graduate and postgraduate cycles. However, it appeared that communication teachers were not enthusiastic about the changes. Although only one senior teacher openly said that a new Bachelor-Master structure is a "step back," other teachers found other ways to express their disagreement with the system of education that is set up to "educate students in a direct and efficient way." They think that the task of universities is to provide a broad liberal education, which will help graduates reach their personal and professional goals, as opposed to a "narrow vocational training" that gives skills but does not liberate minds. Apparently, the Bologna process as a response to globalization has produced tension between the European identity and culture and the necessity to compete in the global business. 


\section{CHAPTER 5}

\section{DISCUSSION}

This study examined public relations teachers' perceptions of ethics education and the status of ethics instruction in the public relations curriculum in the U.S. and foreign universities. Overall, the study participants recognized ethics education as an essential part of the preparation of future professionals. This finding was consistent with a number of studies undertaken in various academic disciplines regarding the importance of ethics instruction at college or university level (e.g., Christians, 2008; McQueeney, 2006; Lambeth, Christians, Fleming, \& Lee, 2004; Chonko, 2004; Lord \& Bjerregaard, 2003; Hutchinson, 2002; Goree, 2000; Harrison, 1990).

Although different methodologies might produce data that might be incompatible (McKee, 2003), a quantitative survey and qualitative interviews employed in this study brought similar results.

The findings also reflected some important changes that ethics education has gone through since its revival in the 1970s. Particularly, Elliott (2007) noted that many educators who do not have a degree in philosophy, were nevertheless successful in developing their philosophical expertise to teach courses in professional ethics. Demographic data in this study supported Elliott's statement. Only 3 participants had their highest degree in philosophy, whereas 51 respondents reported that they taught a separate course in public relations ethics or communication ethics at the college or university level. 
Another finding that reflects changes in higher education experiences these days is the fact that respondents linked the importance of ethics education with the need for such courses at the societal level (Boylan \& Donahue, 2003). A U.S. respondent wrote that one of the goals of ethics instruction was to "Help the students understand the moral purpose associated with their professional role in society." Another U.S. participant said that one of the goals of ethics instruction was "To help students understand that ethical values differ among cultures and change based on new knowledge. They [students] must be able to identify the change needs on the part of organizations to maintain the harmony and stability of the organization." A thought that ethical climate of the profession is dependent on general morality was expressed by a foreign participant, who explained why her university did not have a separate course in public relations ethics: "Its importance in the PR curriculum has not been discovered yet. I think the whole society should believe in it."

\subsection{Moral development.}

The present study is concerned with public relations educators' perceptions of value to students of ethics education through their evaluations of three objectives: contributing in development of moral character, moral reasoning, and specific skills in strategic and persuasive thinking. Rest (1984) argued that four components - moral motivation, moral sensitivity, moral reasoning, and moral character — constitute a model of moral development. Moral character is the ability to remain moral in spite of difficult circumstances, whereas moral reasoning involves choosing action that is the most morally appropriate (Morton, Worthley, Testerman, \& Mahoney, 2006).

This study supported the assumption that in recent years, ethical health of communication professions has been linked to general morality. This tendency was evident, 
for example, in Lambeth et al. (2004) study of journalism and mass communication teachers. The authors surveyed these categories of educators four times in the period from 1977 to 2001-2002. Importantly, the last survey had a new question regarding whether a goal of ethics education was to contribute to the development of moral character. Lambeth et al. (2004) made a point that when asked explicitly about such an instructional goal as contributing to the moral development of students, journalism and mass communication teachers ranked this goal second after the objective of fostering moral reasoning skills.

Participants of the present study were also explicitly asked to evaluate the importance of five goals of ethics education (Table 1), and they ranked such a goal as cultivating moral character as the least important objective of ethics instruction. However, the issue of student moral character was also presented to public relations teachers in the attitude scale (Table 4) in an implicit rather than straightforward manner, along with other two latent variablesadvancing moral reasoning abilities and developing particular professional skills. The fact that the first factor- "moral character"-explained almost 50\% of the total original variance might indicate that participants valued ethics education mainly because they believed in a close tie between general morality and professional ethics. In this regard, Christians and Lambeth (1996) remarked, "Communication ethics cut loose from general morality tends to be self-serving" (p. 237).

Howard and Korver (2008), speculating about distinctions of ethical thinking, said that there is the difference between reasoning and rationalization. The former is "a process of analysis for forming judgments," whereas the latter is "a process of construction justification for a decision we suspect is really flawed" (p. 43). An implication for teaching ethics would be to provide students with a tool necessary to solve ethical dilemmas on the job. 
Participants in this study valued highly such a teaching objective as fostering moral reasoning skills in prospective public relations professionals. This result is consistent with previous research on the topic. As an example, public administration educators ranked a "moral reasoning" strategy as the number one among such conceptual approaches to teaching ethics as "democratic thought," "citizenship," "professional codes of conduct," "virtue and character development," and others (Bowman \& Menzel, 1998). The importance of ethics education as part of preparing students to reason on ethical dilemmas was supported by Lee and Padgett (2000), who argued that moral individuals might be involved in unethical practices due to their ignorance, and one of the ways to avoid it is to train students in moral reasoning. So far, research found (Cabot, 2005) that public relations students had a low level in moral reasoning.

Participants in this study indicated that the development of strategic persuasive skills is an essential part of ethics education. Although the notions of public relations and persuasion are often linked to propaganda (Messina, 2007), the ultimate purpose of the public relations practice is inherently ethical— to build and maintain relationships with key publics through ethical analyses of the organizational policies and communications (Bowen, 2007b). Moreover, Edgett (2002) argued that advocacy, or "the act of publicly representing an individual, organization, or idea with the object of persuading targeted audiences to look favorably on —or accept the point of view—the individual, the organization, or the idea" (p. 1) is a central function of public relations. Edgett (2002) also noted that rhetoric, or the art of persuasive communication has been regarded as a facilitator of debates in democracy for a long time. 
Presumably, the university is the place where future public relations professionals begin to learn practical techniques of professional persuasion, and one task of educators is to connect the techniques with ethics, thus, providing guidance for ethically sounded strategic communication.

\subsection{Goals of ethics education through international lenses.}

A number of studies have examined the status of ethics instruction in U.S. university departments (Christians \& Lambeth, 1996; Lee \& Padgett, 2000; Lambeth et al., 2004; Canary, 2007). The present research appeared to be the first to explore the current perspectives on ethics education in the world scope. Importantly, Day et al. (2000) called ethics in international public relations one of the most significant issues for the $21^{\text {st }}$ century.

The findings in this study indicated that there were similarities and differences in teachers' beliefs in goals of ethics education depending on the country of origin and country in which respondents currently teach. Means indicated (Table 2) that compared to two groups of participants (those who were born and teach in the US and those who were born abroad but teach in the U.S.), respondents who were born and teach abroad were less enthusiastic about all five goals of ethics education—cultivating moral character, improving the moral cognitive capacities of public relations students, familiarizing them with ethical theories, developing socially responsible professionals, and helping students make good choices on the job.

However, only one difference — in perceptions of the last goal—reached its statistical significance, allowing an inference that compared to American teachers, their foreign counterparts were more realistic or skeptical about the environment in which future professionals would work. Elliott (2007) argued, "Environments encourage and discourage 
moral growth and development" (p. 74). McBride cited in South (2004) said that journalism students tend to lose ethical strengths when they move to the professional world, because "newsrooms reinforce the principles of competition, ego and capitalism" (p. 11); these principles are not journalistic beliefs. The same discrepancy—between what students were taught at the university and what they experience in the workplace - might apply to public relations graduates (Martinson, 2000).

Another possible explanation of the fact that foreign teachers believed that even being prepared to solve ethical dilemmas, public relations graduates might make unethical decisions is presumably educators' belief that instead of making tough decisions, graduates would prefer to keep their jobs or avoid financial losses. As qualitative interviews showed, European teachers perceive the two-way symmetrical model, which is a "most ambitious one, especially in theoretical and ethical terms" (Nessmann, 1995) as rather utopian and illusory. In this regard, foreign public relations instructors' attitudes need a further investigation to see what factors (economic, political, social, professional, organizational, and (or) personal) influence their teaching philosophies.

Another quandary discovered in the study that deserves future investigation is an association between participants' ranks and their perceptions of value to students of ethics education. This study found that the higher rank the teacher had, the less he or she believed in the value to students of ethics education. A subsequent correlation test showed a negative association between the educator's rank and years of experience in the public relations industry. It seems logical — the earlier a person starts a career in the academia, the less industry experience he or she has. What intrigues is the tendency to value less ethics education by those who have significant academic experience and do not have a substantial 
professional practice. Whether these participants are skeptical of public relations education or practice, or they do not strongly believe in students' ethical growth, or whether there are other variables that influence high rank educators' attitudes - these questions need further examination.

According to Elliott (2007), moral development happens within two contextspersonal and professional. A recent trend in teaching ethics has been the educators' focus not only on the individual practitioner who faces ethical dilemmas (a micro level) but also they examine how his or her profession operates in society (a macro level) (Elliott, 2007). University education might be considered an introduction into the public relations profession, and thus, educators are responsible for creating an environment that promotes the growth of moral sophistication. In Mahin's (1998) words, “All teaching is value-laden (p. 76), and for a teacher, "the right thing to do" becomes his or her involvement in fostering moral maturity of prospective professionals.

\subsection{Attitudes toward format of ethics delivery.}

Two decades ago, only one in four universities offered a course in communication ethics (Harrison, 1990). According to the report provided by participants in this study, $60 \%$ of universities offered a course in public relations or communication/media ethics in 2008. This fact might indicate that the system of higher education has begun the process of a "moral reconceptualizing" (Long, 1992). As for the method of ethics instruction delivery, regardless of the country of origin and country in which respondents currently teach, the majority of participants regarded ethics incorporated throughout the curriculum as the best format of ethics instruction delivery. 
Those who believed in a free-standing course chose ethics instruction as a separate PR ethics course over ethics instruction as a separate communication ethics course. This might be evidence of a long-term tension between public relations and other departments, primarily journalism, which has been accused of dominating over the public relations sequence or department (Harrison, 1990). Or it might be a reflection of public relations educators' beliefs that professional ethics is complex and multidimensional, and the course cannot be watered-down by issues that do not have direct relevance to public relations theories and practice. As the Commission on Public Relations education (2006) noted, "Coursework and instruction dedicated to mass media ethics cannot fully satisfy the needs of public relations professional education" (p. 23).

\subsection{Pedagogies in teaching ethics.}

Although university instructors design ethics course differently (Plaisance, 2007), pedagogies, resources, and evaluation tools might significantly overlap. One of the goals of the present study was to examine public relations educators' perceptions of the effectiveness of pedagogical techniques and materials that they use in the classroom. Previously, PR teachers agreed that the best teaching strategies are those that help students put theory into practice (Coombs \& Rybacki, 1999). Importantly, there is probably no a single learning pedagogy that is able to achieve all outcomes desired by teachers (Flannery \& Pragman, 2008). It is a matter of the combination and thoughtful usage of techniques that facilitate students' personal and professional development.

In the present study, case study, group discussion, and teacher lectures occupied the first three places in instructors' hierarchy, being the most used and most effective pedagogies in teaching ethics to public relations students. In this regard, Christians (2008) named case 
study "the most dominant pedagogical technique" (p. 191), whereas Pauly and Hutchinson (2000) suggested that public relations teachers can help students become reflective professionals by using case study in the classroom. Canary (2007) found that the use of case studies as an instructional method resulted in higher degree of student moral reasoning, compared to other pedagogies.

Importantly, the quality of case studies offered by textbooks and journals has been significantly improved in the last four decades (Pauly \& Hutchinson, 2000). Not surprisingly, participants in this study ranked ethical decision-making case study highly. This finding was consistent with a previous research of teaching techniques preferred by professors and students (Hanson, 2002; Braun, 1999).

Group discussions were highly regarded in a previous study (Coombs \& Rybacki, 1999), in which public relations teachers regarded this pedagogy as having potential to expand active learning through the inclusion of student voices. Silverman cited in Lieberman (1997) emphasized the effectiveness of class discussions by providing the following statistics: U.S. students are able to retain $10 \%$ of what they read and $70 \%$ of what they say.

Although class lectures were not associated with active learning, they were found to be effective in large classes and they were regarded as effective if lectures are delivered in an engaging and enthusiastic manner (Coombs \& Rybacki, 1999). Elliott (2007) echoed this assumption by suggesting that "good teaching ethics" can be done through lecture if students have a chance to express their views.

Research papers and Socratic dialogs were on the bottom of the effectiveness list in the present study. The low rating of the former pedagogy might have revealed teachers' concern with the Internet plagiarism, or retrieving information without references to online 
sources. The accessibility of Internet material increases student plagiarism (Baggaley \& Spencer, 2005) and might lead to the situation when teachers perceive written assignment useless.

Considering the fact that participants in this project rated case study as the most important pedagogy in teaching ethics, it was not clear why a Socratic method of questioning was the least used and regarded as one of the least effective technique. The rationale of linking two methods — case study and Socratic dialogue — is their active-learning nature, or active discussions and probing student comprehension of underlying principles involved in the case (McQueeney, 2006; Parkinson \& Ekachai, 2002). Moreover, Altshul and Woolverton cited in Parkinson and Ekachai (2002) argued that a Socratic method is "better suited" to teach public relations undergraduate courses than the lecture approach. Definitely, a Socratic dialogue is an essential technique for the discussion of ethical dilemmas where clear-cut answers are hardly possible and where the teacher strives to avoid moralism and indoctrination (Christians \& Lambeth, 1996).

Perhaps one reason the Socratic method was scored lower is because teachers are simply less comfortable or experienced in using, compared to other pedagogies. This is an area of further investigation.

\subsection{Resources in ethics instruction.}

Public relations educators rated newspaper or magazine stories, trade magazine articles, and textbooks as the most effective resources in teaching ethics to public relations students. The fact that media publications were chosen over textbooks might have reflected at least two issues in public relations education. First, it showed teachers' dissatisfaction with available textbook options that had been a concern for decades (Coombs \& Rybacki, 1999; 
Harrison, 1990; Bivins, 1989). Second, it showed teachers' attempts to keep up with current events in the public relations practice by bringing them into classroom discussions.

Public relations teachers perceived academic journal articles and blogs as the least effective materials in ethics instruction. As for published research studies, educators might argue that they could be too complicated for students' understanding of issues of public relations professional ethics. The fact that blogs appeared to be the least used and least effective resource in teaching ethics needs a future investigation. It might be implied that because the Internet represents a friendly environment for young people, teachers would take advantage of students' involvement in online activities.

Instructors' focus on online activities might be especially useful these days, when thousands of businesses and enterprises throughout the world have acknowledged competitive advantages of the Internet and actively use blogs in their public relations practices (Marken, 2006/2007). One respondent provided a new venue in using blogs in ethics classroom: "I haven't used blogs as a reading source, but I have had students create blogs to discuss professional ethics.” Again, perhaps blogs and other new technologies are used less, or valued less by educators because they are less comfortable or familiar with them. In this regard, while delivering his lecture at Public Relations Council of Alabama's 2008 Annual conference, Robert French, a university instructor with 25 years of experience in teaching public relations, pointed out that teachers should be the first in introducing social media to PR students. In reality, according to French's observations, the teachers are the last to familiarize students with emerging digital media. 


\subsection{Evaluating student learning.}

As for assessment tools, public relations educators considered written case studies, individual and panel presentations, and individual projects as the most effective methods to evaluate student learning, whereas written examinations and term papers appeared to be less valuable approaches. An important finding of this study is that respondents, using most often written examinations as an assessment tool, did not rank highly its effectiveness. Before implying that routine has won over creativity in public relations departments, one should consider the fact that written examinations, which are mostly designed as multiple choice exams, represent the most objective way of testing student knowledge. Importantly, Maureen Taylor (personal communication, August 7, 2008) distinguished between "evaluating" and "testing" students.

The challenge is to combine simple techniques - quizzes and tests—with more profound assessment methods while measuring the depth and breadth of student comprehension of ethical issues. In this regard, a highly rated pedagogy (e.g., case study) might become an effective technique for evaluating of student learning when the students are asked to write a paper, reflecting on a case that just has been reported by the media. The trinity—pedagogies, resources, and assessment tools—are crucial in every educational course. What makes the trinity stand out in the case of teaching public professional ethics is the necessity to prepare professionals who are able to be ethical and proactive in their decision making, while performing dual-advocacy duties - to the organization and public.

\subsection{Similarities and differences in teaching philosophies and practices of American and European teachers.}

The two groups demonstrated similar attitudes toward ethics instruction in the public relations curriculum, seeing it as an important aspect of communication education. However, 
while American educators called for a more thorough instruction in the professional ethics, European teachers emphasized the need to educate communication professionals who are experts in ethics in the philosophical sense. Thus, two different dimensions of ethics education emerged: Ethics instruction that helps students comprehend and subscribe to norms and behaviors of the PR profession (normative ethics), and ethics instruction that helps student to understand the nature of moral thought and practice (meta-ethics).

Importantly, both American and European educators were concerned with evaluation of student learning, saying that they might be able to evaluate students' performances in class, but they are not able to predict what framework graduates choose in the practice public relations and personal lives.

The specifics of the system of higher education in the U.S. and Europe led to the situation in which American PR educators feel obligated to help the industry thrive, while European educators distance themselves from the industry seeing universities as autonomous enterprises that are not "accepting orders" from practitioners. Accordingly, approaches in teaching ethics differ in the U.S. and Europe. While American teachers believe that good examples are able to induce moral behavior (Pratt, 1991), Europeans educators tend to focus on negative cases. One of the explanations of such a strategy of European teachers is the fact that $85 \%$ of PR practice is asymmetrical (press agentry, public information, the two-way asymmetrical model) (Nessmann, 1995). Moreover, Benson (2008) appealed to PR professionals and educators to set "realistic ground rules" and "abandon an ethical and intellectual project that suffers from a real 'legitimation' crisis” (p. 18).

While analyzing a number of public relations cross-national research projects, Nessmann (1995) said that these studies showed a great impact of culture on practical PR. In 
regard to a cross-cultural comparison, the present study found that in the same manner as PR practices reflect national specifics of the countries in which pubic relations activities take place, PR educational philosophies reflect national PR practices and broader societal contexts. Thus, the teaching philosophies might diverge, and in some cases, quite sharply. It means that there might not be an opportunity to generalize educational practices even within Europe (Vercic, van Ruler, Butschi, \& Flodin, 2001; Nessmann, 1995), needless to say, in the global scope. However, an attempt to uncover similarities among national PR practices continue to attract scholars' attention (Vercic et al., 2001), and there is a hope that a research interest on educational practices will be increased as well.

Finally, it is important to underline that a leitmotiv of qualitative interviews was that universities as advanced academic communities should perform a dual service to society: to disseminate knowledge and provide guidance for the responsible use of knowledge.

\subsection{Conclusion}

In the 1980s, ethics moved from its isolation in university philosophy departments and became increasingly accessible for students of medicine, business, law, communication, and many other disciplines (Christians \& Lambeth, 1996). The challenge of the present day is "to ground media ethics education in the general morality, not first of all professional ethics" (Christians, 2008, p. 191). The reason is that when communication practitioners live up to their professional norms, they might prioritize the principles that can be self-serving and defensive, whereas general morality provides communicators with the opportunity to be on the same page with the public to whom they serve (Christians, 2008). An implication for public relations education is to implement a program that emphasizes "the-sacredness-of-life principle" (Christians \& Nordenstreng, 2004) as the main framework for understanding and 
evaluating professional ethics concepts. In this regard, the Commission on Public Relations education (2006) suggested that public relations practitioners determine their actions within their society's moral parameters.

The present study found that although public relations teachers valued highly ethics education, they were careful in defining their roles as mentors who cultivate moral character of students. Rather, they perceived themselves as educators who contribute in developing inherent moral capacities of future public relations professionals. According to the Commission on Public Relations education (2006), ethical values "can and must be taught to students who hopefully will accept and assimilate these common values" (p. 24). This might be a key issue in ethics education: To prepare public relations graduates to advise management on ethical dilemmas (Bowen, 2007b). As this project and others suggest the "how best to do that" remains an open question.

Not diminishing the importance of existing research on crisis communication, this study calls for a more intensive research on public relations ethics as a means of preventing crisis situations in public relations practice. Professional success in public relations like in any other occupation starts with education. The Latin root of the word education (educare) means "to lead out;" accordingly, education is the leading-out process, in which students advance their level of understanding and enhance their knowledge (Boylan \& Donahue, 2003). Today, formal education is tightly connected to ethics education to provide students with a framework necessary for analysis of ethical dilemmas embedded in the profession. By learning how to make professional decisions based on a moral context, practitioners perform their duties with societal expectations. In other words, they act in behalf of the public and common good. 
Participants' reports showed that the number of ethics courses offered by communication departments has grown significantly in the last 20 years. Now 6 out 10 universities have such a course, compared to 1 out 4 universities previously. This might be a sign that universities have moved from "merely transmitters of facts and information" into "dynamic centers of inquiry" where students improve the "mode of moral knowing" (Boylan \& Donahue, 2003, p. 4). It also might suggest that more universities seek to comply with the recommendations of certification and accreditation bodies regarding the need for more ethics instruction.

In the end of the $20^{\text {th }}$ century, those who opposed ethics courses in the university curriculum demanded "hard evidence" that such courses would improve the moral attitude and behavior of graduates. A growing number of ethics courses indicates a growing understanding that such evidence is unavailable due to the fact that it is impossible to hold every variable constant except a single ethics course while assessing whether student morality has been improved (Wines, 2008). Furthermore, there are no expectations that any university course is supposed to become a "life-changing" event. Rather, Wines (2008) argued, education helps students "to take charge of their intellects" and prepare them "to take a meaningful role in participatory government as an active and informed citizen" (p. 485). In other words, a university encourages not only intellectual development but also moral and social growth.

Scholarship on ethics education provides directions for future research in the university setting. Elliott (2007) said that the Hastings Center's book, Teaching Ethics in Higher Education, provided educators with a conceptual foundation for establishing and improving ethics courses at college and university level. Elliott believed that "the experiment 
has failed" (p. 39) because today, 25 years later after the book was published, there are still professionals who do not live up to high ethical standards. Will educators support Deni Elliott's opinion? Or they will agree with another scholar—Robin Barrow (2007)? The later author distinguished between a morally educated and moral person by arguing that a morally educated individual understands the nature of morality, but this understanding does not prevent him from ethical failures, whereas a moral person might not have formal ethics education but nevertheless he or she will act ethically. Barrow (2007) reasoned that

[W]e cannot assume that the test of successful moral education is simply the extent to which students go on to lead moral lives, and we should not be assessing the quality of the moral education we provide by estimating the improvement or decline in moral conduct in society (p. 166-167).

Barrow (2007) argued that while most people acquire moral understanding, which is an essential aspect of being moral, through formal education, universities should continue its attempts to develop moral understanding in students.

Both authors—Elliott and Barrow—-triggered such an important issue as the assessment of a long-term effect of ethics education. Participants in this study indicated the most effective and least effective methods of evaluation of a short-term effect of student learning - the assessment that happens in the classroom. Gale and Bunton's (2005) widelycited survey of advertising and public relations professionals was based on self-reports, and a question of whether there are other methods of evaluating the impact of ethics instruction on an individual and aggregated levels remains open. Meanwhile, such an examination done in the work settings might uncover problematic issues and have implications for public relations education. Such research will provide teachers with ideas of how classroom instruction can 
increase moral resistance to unethical practices that graduates might face in the future. Post graduate ethics training provided by professional organizations have a potential to reinforce ethics beliefs formed in the undergraduate years. An overall thought is that ethics education does not start and does not finish in the university walls, but during the four years, students have an opportunity to build moral fortress that will protect their integrity in tough situations at the workplace. Moreover, students should have strength not only to avoid involvement in unethical practices but also to confront unethical decisions of those who in power.

\subsubsection{Future Research}

Future research should focus on such issues as (1) whether and to what extent ethics is not only teaching but research interest of public relations teachers; (2) the content of ethics courses; (3) theoretical systems (e.g., Judeo-Christian ethics, Kantian deontology, utilitarianism, and others) examined in the course; and, the most important, whether and to what extent ethics instruction affects public relations graduates' future as individuals and professionals. A quantitative approach employed in the study aggregated its results, and this aspect calls for future qualitative research to examine individual differences in educators' perceptions of various dimensions of ethics education.

\subsubsection{Limitations}

This study has several limitations that must be noted. First, it is based on self-reports which can be associated with the social desirability issue. Second, although the number of respondents was enough to generalize to members of the Association for Education in Journalism and Mass Communication, International Communication Association, National Communication Association, and Educator's Academy of the Public Relations Society of America, one should be careful with generalizing to the overall population of U.S. and 
foreign public relations educators. The reason is that not every person who teaches public relations courses at college or university level is a member of one of the organizations mentioned above. This is especially true about foreign teachers who are not well-represented in the U.S.-based academic organizations. Importantly, educators who teach abroad might have teaching objectives that might be both similar and different from educational philosophies of U.S. instructors. Thus, more research in international settings is needed.

\subsubsection{Research Contributions}

Anecdotal data show that despite a rapidly growing interest in public relations ethics, few studies have examined the state of teaching ethics to public relations students at the university level (Bowen, 2005). This paper makes a pedagogical and theoretical contribution to a thin literature on ethics education. Research based on examination of teachers' perceptions and preferences may help public relations educators see trends in contemporary education, better understand their underpinnings, and possibly enhance their own teaching and educational curricula. Believing in Chonko's (2004) statement that "Ethics education may not be able to change the world, but it may be able to influence some" (p. 40), an empirical effort to examine the ways and methods teachers employ to contribute to student moral character is worthwhile.

In addition, public relations ethics education is only one link in a much longer chain: the choices that practitioners make about ethical dilemmas are also influenced by parents and upbringing, reference groups, personal experience and ambitions, professional colleagues and the organization(s) in which they work. 


\section{REFERENCES}

Adams, G. P., Ducasse, C. J., Everett, W. G., Parker, D., Sharp, F. C, \& Turfs, J. H. (1932). A symposium: The aim and content of graduate training in ethics. International Journal of Ethics, 43, 53-64.

Adrian, W. (2005). Truth, freedom and (dis)order. Christian Higher Education, 4, 145-154.

Allert, J. R. (1999). Ethics in communication: The role of public relations. In S.K.

Chakraborty and S.R. Chatterjee (Eds.), Applied ethics in management, pp. 187-203.

Azarova, L. (2003). Public relations higher education-a Russian experience. Higher Education in Europe, 28, 495-498.

Baggaley, J, \& Spencer, B. (2005). The mind of a plagiarist. Learning, Media and Technology, 30, 55-62.

Baker, S., \& Martinson, D. L. (2002, Fall). Out of the red-light district: Five principles for ethically proactive public relations. Public Relations Quarterly, 15-19.

Barrow, R. (2007). An introduction to moral philosophy and moral education. New York, NY: Routledge.

Benson, R. (2008). Public relations in the public sphere: Habermas, Bourdieu, and the question of power. Paper presented at the International Communication Association annual meeting, Montreal, Canada, May, 2008.

Berger, B. (2008). Report on leadership in public relations. Paper presented at the Southern Public Relations Federation meeting, Sandestin, FL, July, 2008.

Berger, B. K., Reber, B. H., \& Heyman, W. C. (2007). You can't homogenize success in communication management: PR leaders take diverse paths to top. International Journal of Strategic Communication, 1, 53-71.

Berger, B. K., \& Reber, B. H. (2006). Gaining Influence in Public Relations: The Role of Resistance in Practice. Mahwah, NJ: Lawrence Erlbaum Associates.

Berger, J., \& Pratt, C. B. (1998). Teaching business-communication ethics with controversial films. Journal of Business Ethics, 17, 1817-1823. 
Bivins, T. H. (1992). A systems model for ethical decision making in public relations. Public Relations Review, 18, 365-383.

Bivins, T. H. (1991, Winter). A theory-based approach to public relations ethics. Educator, $39-44$.

Bivins, T. H. (1989). Are public relations texts covering ethics adequately? Journal of Mass Media Ethics, 4, 39-52.

Bok, D. C. (1976, October). Can ethics be taught? Change, p. 30.

Bowen, S. A. (2008). Foundations in moral philosophy for public relations ethics. In T. L. Hansen-Horn and B. D. Neff, Public relations: From theory to practice, pp. 160-180.

Bowen, S. A. (2007a). The extent of ethics. In E. L. Toth (Ed.), The future of excellence in public relations and communication management. Challenges for the next generation, pp. 275-297. Mahwah, NJ: Lawrence Erlbaum Associates.

Bowen, S.A. (2007b). Ethics and public relations. Gainesville, FL: Institute for Public Relations.

Bowen, S. A. (2005). A practical model for ethical decision making in issues management and public relations. Journal of Public Relations Research, 17, 191-216.

Bowman, J., \& Menzel, D. (1998). Introduction. In J. Bowman and D. Menzel (Eds.), Teaching ethics and values in public administration programs, pp. 1-17. Albany, NY: State University of New York Press.

Boyd, J. (2004). A different kind of [Text]book: Using fiction in the classroom. Communication Education, 53, 340-347.

Boylan, M., \& Donahue, J. A. (2003). Ethics across the curriculum. A practice-based approach. Lanham, MD: Lexington Books.

Boynton, L. A. (2002). Professionalism and social responsibility: Foundations of public relations ethics. In W. B. Gudykunst (Ed.), Communication yearbook, 26, pp. 230265.

Braun, M. J. (1999). Media ethics education: A comparison of student responses. Journal of Mass Media Ethics, 14, 171-182.

Bunch, W. H. (2005). Changing moral judgment in divinity students. Journal of Moral Education, 34, 363-370.

Burton, B. (2007). Inside spin. The dark underbelly of the PR industry. Crows Nest, Australia: Allen \& Unwin. 
Cabot, M. (2005). Moral development and PR ethics. Journal of Mass Media Ethics, 20, 321332.

Caddick, S. (2008). Back to Bologna. The long road to European higher education reform. Science \& Society (EMBO Reports), 9, 18-21.

Callahan, D. (1980). Goals in the teaching of ethics. In D. Callahan and S. Bok, (Eds.), Ethics teaching in higher education, pp. 61-80. New York: Plenum Press.

Callahan, D., \& Bok, S. (1980). Ethics teaching in higher education. New York: Plenum Press.

Camenisch, P. F. (1986). Goals of applied ethics courses. The Journal of Higher Education, 57, 493-509.

Canary, H. E. (2007). Teaching ethics inn communication courses: An investigation of instructional methods, course foci, and student outcomes. Communication Education, 56, 193-208.

Carey, J. L. (1947). The realties of professional ethics. The Accounting Review, 22, 119-123.

Chandler, R. C. (2007). Rationale for comprehensive corporate ethics training initiatives and role for remedial ethics training. Paper presented at the National Communication Association annual meeting, Chicago, IL, November, 2007.

Chonko, L.B. (2004). Casuistry and change readiness: Fundamental aspects of teaching ethics in marketing decision making. Marketing Education Review, 14, $23-45$.

Christians, C. G. (2008). Media ethics in education. Journalism Communication Monographs, 9, 181-221.

Christians, C. G. (1979). Beyond quandaries: A plea for normative ethics. Mass Communication Review, 6, 28-31.

Christians, C. G., \& Nordenstreng, K. (2004). Social responsibility worldwide. Journal of Mass Media Ethics, 19, 3-28.

Christians, C. G., \& Lambeth, E. B. (1996, July). The status of ethics instruction in communication departments. Communication Education, 45, 236-243

Commission on Public Relations Education. (2006). The professional bond-public relations education and practice. New York: Public Relations Society of America.

Commission on Public Relations Education. (1999). Public Relations Education for the 21st Century: A Port of Entry. New York: Public Relations Society of America. 
Cook, C., Heath, F., \& Thompson, R.L. (2000). A meta-analysis of response rates in Web- or Internet-based surveys. Educational and Psychological Measurement, 60, 821-836.

Coombs, W. T., \& Rybacki, K. (1999). Public relations education: Where is pedagogy? Public Relations Review, 25, 55-63.

Currie, J., DeAngelis, R., de Boer, H., Huisman, J., \& Lacotte, C. (2002). Introduction. In J. Currie, R. DeAngelis, H. de Boer, J. Huisman, \& C. Lacotte (Eds.), Globalizing practices and university responses. European and Anglo-American perspectives, pp. 1-21. Westport, CT: Praeger.

Curtin, P. A., \& Gaither, T. K. (2007). Ethical considerations in global practice. In P. A. Curtin and T. K. Gaither, (Eds.) International public relations. Negotiating culture, identity, and power, pp. 235-252. Thousand Oaks, CA: Sage.

Curtin, P. A., \& Boyton, L. A. (2001). Ethics in public relations. Theory and practice. In R. L. Heath (Ed.), Handbook of public relations, pp. 411-421. Thousand Oaks, CA: Sage.

Day, K. D., Dong, Q., \& Robins, C. (2000). Public relations ethics. An overview and discussion of issues for the $21^{\text {st }}$ century. In R. L. Heath (Ed.), Handbook of public relations, pp. 403-409. Thousand Oaks, CA: Sage.

Denzin, N. K. (1994). The art and politics of interpretation. In N. K. Denzin \& Y. S. Lincoln (Eds.), Handbook of qualitative research (pp. 500-515). Thousand Oaks, CA: Sage.

Dube L. F., \& Wingfield, S. S. (2008). Economics, sociology, politics, and religion: Success of marketing students. Atlantic Economic Journal, 36, 503-504.

Duffy, M. E. (2000). There's no two way symmetric about: A postmodern examination of public relations textbooks. Critical Studies in Media Communication, 17, 294-315.

Edgett, R. (2002). Toward an ethical framework for advocacy in public relations. Journal of Public Relations Research, 14, 1-26

Elliott, D. (2007). Ethics in the first person. A guide to teaching and learning practical ethics. Lanham, MD: Rowman \& Littlefield Publishers.

Elliott, G, \& Koper, E. (2002). Public relations education from an editor's perspective. Journal of Communication Management, 7, 21-33.

Ellwood, C. A. (1910). The sociological basis of ethics. International Journal of Ethics, 20, 314-329.

Flannery, B. L., \& Pragman, C. H. (2008). Working towards empirically-based continuous improvements in service learning. Journal of Business Ethics, 80, 465-479. 
Gale, K., \& Bunton, K. (2005). Assessing the impact of ethics instruction on advertising and public relations graduates. Journalism and Mass Communication Educator, 60, 272285.

George, A. M. (2003). Teaching culture: The challenges and opportunities of international public relations. Business Communication Quarterly, 66, 97-113.

Goree, K. (2000). Teaching moral development in journalism education. Journal of Mass Media Ethics, 15, 101-114.

Goodpaster, K. E. (2002). Teaching and learning ethics by the case method. In N. E. Bowie (Ed.), The Blackwell guide to business ethics, pp. 117-141. Malden, MA: Blackwell Publishers.

Grunig, J. E. (1992). Excellence in public relations and communication management. Hillsdale, NJ: Lawrence Erlbaum Associates.

Grunig, J. E., \& Grunig, L. A. (1991). Conceptual differences in public relations and marketing: the case of health-care organizations. Public Relations Review, 17, 257278.

Hall, S. (1991). The local and the global: Globalization and ethnicities. In A.D. King (Ed.), Culture, globalization, and the world system, pp. 19-30. London, UK: Macmillan.

Hanson, G. (2002). Learning journalism ethics: The classroom versus the real world. Journal of Mass Media Ethics, 17, 235-247.

Harrison, S. L. (1990). Ethics and moral issues in public relations curricula. Journalism Educator, 45, 32-38.

Hayes, R. (2008). Public relations and collaboration: The role of public relations and communications supporting collaboration in a complex, converging world. IPRA Gold paper No. 17. Retrieved December 16, 2008 from http://www.lulu.com/content/4602019.

Heath, R. L. (1991). Public relations research and education: Agendas for the 1990s. Public Relations Review, 17, 185-194.

Heika-Ekins, A. (1988). Teaching ethics in public administration. Public Administration Review, 48, 885-891.

Hostetter, D. R. (2007). Universitas and moral excellence. Higher education and the judicious use of knowledge. Lanham, MA: University Press of America.

Howard, R. A., \& Korver, C. D. (2008). Ethics for real world. Creating a personal code to guide decisions in work and life. Boston, MA: Harvard Business Press. 
Hutchinson, L. L. (2002). Teaching ethics across the public relations curriculum. Public Relations Review, 28, 301-309.

Jaffe, S., \& Hyde, J. S. (2000). Gender differences in moral orientation: A meta-analysis. Psychological Bulletin, 126, 703-726.

Johnson, C. E. (2005). Meeting the ethical challenges of leadership. Casting light or shadow $\left(2^{\text {nd }}\right.$ ed.). Thousand Oaks, CA: Sage.

Kruckeberg, D. (1998). The future of PR education: Some recommendations. Public Relations Review, 24, 235-248.

Lambeth, E. B., Christians, C. G., Fleming, K., \& Lee, S. T. (2004, Fall). Media ethics teaching in century 21: Progress, problems, and challenges. Journalism \& Mass Communication Educator, 239-258.

Lee, D. S. (1990). The difficulty with ethics education in public administration. International Journal of Public Administration, 13, 181-205.

Lee, D. S., \& Paddock, S. C. (1992). Improving the effectiveness of teaching public administration ethics. Public Productivity and Management Review, 15, 487-500.

Lee, B., \& Padgett, G. (2000). Evaluating the effectiveness of a mass media ethics course. Journalism and Mass Communication Education, 55, 27-39.

Leichty, G. (2003). The cultural tribes of public relations. Journal of Public Relations Research, 15, 277-304.

L'Etang, J. (2008). Public relations. Concepts, practice and critics. London, UK: Sage Publications.

L'Etang, J. (2003). The myth of the 'ethical guardian': An examination of its origins, potency and illusions. Journal of Communication Management, 8, 53-67.

Leys, W. A. R. (1950). Current application of ethical theory. The Journal of Higher Education, 21, 415-418.

Lieberman, D. A. (1997). Culture, problem-solving, and pedagogical style. In L.A. Samovar and R.E. Porter (Eds.), Intercultural communication. A reader ( $8^{\text {th }}$ ed.), pp. 191-207.

Lincoln, Y. G., \& Guba, E. G. (1985). Naturalistic inquiry. Beverly Hills, CA: Sage Publications.

Lisman, C.D. (1996). The curricular integration of ethics: Theory and practice. Westport, CT: Praeger. 
Long, E. L. (1992). Higher education as a moral enterprise. Washington, DC: Georgetown University Press.

Lord, V. B., \& Bjerregaard, B. E. (2003). Ethics courses: Their impact on the values and ethical decisions of criminal justice students. Journal of Criminal Justice Education, $14,191-211$.

Ludlum, M. P., \& Moskaloinov, S. (2005). Russian student views on business ethics: PostEnron. College Student Journal, 39, 156-164.

Mahin, 1L. (1998). Critical thinking and business ethics. Business Communication Quarterly, 61, 74-78.

Marken, G. A. (2006/2007, Winter). Blogosphere or blog with fear. Public Relations Quarterly, 51, 33-35.

Marshall, C., \& Rossman, G. B. (1989). Designing qualitative research. Newbury Park, CA: Sage.

Martinson, D. L. (2000, Fall). Ethical decision making in public relations: What would Aristotle say? Public Relations Quarterly, 18-21.

McDaniel, C. (2004). Organizational ethics. Research and ethical environments. Burlington, VT: Ashgate Publishing Company.

McInerny, P.M. (1997-1998, Winter). Ethics throughout the curriculum. Public Relations Quarterly, 42, 44-47.

McKee, A. (2003). Textual analysis: A beginner's guide. London, UK: SAGE.

McKie, D., \& Munshi, D. (2007). Reconfiguring public relations. Ecology, equity, and enterprise. New York: Routledge.

McQueeney, E. (2006). Making ethics come alive. Business Communication Quarterly, 69, 158-171.

Mendonca, M., \& Kanungo, R. N. (2007). Ethical leadership. New York: Open University Press.

Messina, A. (2007). Public relations, the public interest and persuasion: An ethical approach. Journal of Communication Manager, 11, 29-52.

Morton, K. R., Worthley, J. S., Testerman, J. K., \& Mahoney, M. L. (2006). Defining features of moral sensitivity and moral motivation: Pathways to moral reasoning in medical students. Journal of Moral Education, 35, 387-406. 
Neff, B. D., Walker, G., Smith, M. F., \& Creedon, P. J. (1999). Outcomes desired by practitioners and academics. Public Relations Review, 25, 29-44.

Nelson, R. A. (2003). Ethics and social issues in business: an updated communication perspective. Competitiveness Review, 13, 66-74.

Nessmann, K. (1995). Public relations in Europe: A comparison with the United States. Public Relations Review, 21, 151-160.

Nunnally, J.C. (1978). Psychometric theory, 2nd ed. New York: McGraw-Hill.

Owen-Smith, J., Riccaboni, M., Rammolli, F., \& Powell, W.W. (2002). A comparison of U.S. and European university-industry relations in the life science. Management Science, 48, 24-43.

Paluszek, J. (1989). Public relations and ethical leadership. Vital Speeches of the Day, 55, $747-750$.

Parkinson, M. G., \& Ekachai, D. (2002). The Socratic method in the introductory PR course: An alternative pedagogy. Public Relations Review, 28, 167-174.

Pauly, J, J., \& Hutchinson, L. L. (2000). Case studies and their use in public relations. In R. L. Heath (Ed.), Handbook of public relations, pp. 381-388. Thousand Oaks, CA: Sage.

Pearson, R. (1989). Business ethics as communication ethics: Public relations practice and the idea of dialogue. In C.H. Botan and V. Hazleton (Eds.), Public relations theory (pp. 111-131). Hillsdale, NJ: Lawrence Erlbaum.

Pierce, A.R. (2007). Woodrow Wilson and Harry Truman: Mission and Power in American Foreign Policy. Edison, NJ: Transaction Publishers.

Plaisance, P. L. (2007, Winter). An assessment of media ethics education: Course content and the values and ethical ideologies of media ethics students. Journalism and Mass Communication Educator, 378-396.

Pratt, C. B. (1991). Public relations: the empirical research on practitioner ethics. Journal of Business Ethics, 10, 229-236.

Radest, H. B. (1989). Can we teach ethics? New York: Praeger.

Report by the Hastingss Center. (1980). The teaching of ethics in higher education. New York: The Hastings Center.

Rest, J. R. (1986). Moral development: advances in research and theory. New York: Praeger Publishers. 
Rest, J. R. (1984). The major components of morality. In W. M. Kurtines and J. L. Gewirtz (Eds.), Morality, moral behavior and moral development. New York, NY: John Wiley \& Sons, pp. 24-38.

Reyhold, S. J. (2006). Moral awareness and ethical predispositions: Investigating the role of individual differences in the recognition of moral issues. Journal of Applied Psychology, 21, 233-243.

Rizvi, F., Engel, L., Ruthkowski, D., \& Sparks, J. (2007). Equality and the politics of globalization in education. In G. K. Verma, C. R. Bagley, and M. M. Jha (Eds.), International perspectives on educational diversity and inclusion. Studies from America, Europe and India, pp. 3-20. New York, NY: Routledge.

Phode, D. L. (2006). Introduction: Where is the leadership in moral leadership? In D. L. Phode (Ed.), Moral leadership. The theory and practice of power, judgment, and policy, pp. 1-53. San Francisco, CA: Jossey-Bass.

Rosen, B. (1980). The teaching of undergraduate ethics. In D. Callahan and S. Bok, (Eds.), Ethics teaching in higher education, pp. 171-189. New York: Plenum Press.

Rosen, B., \& Caplan, A. L. (1980). Ethics in the undergraduate curriculum. New York: The Hastingss Center.

Rothblatt, S., \& Wittrock, B. (1993). Introduction: universities and 'higher education.' In S. Rothblatt and B. Wittrock (Eds.), The European and American university since 1800. Historical and sociological essays, pp. 1-15. Cambridge, MA: Cambridge University Press.

Ryan, M., \& Martinson, D. L. (1984). Ethical values, the flow of journalistic information and public relations persons. Journalism Quarterly, 61, 27-34.

Saunders, M. D., \& Perrigo, E. (1998, Winter). Negotiation as a model for teaching public relations professionalism. Journalism and Mass Communication Educator, 57-65.

Seccion Especial (2004, March). The Latest Mergers: Why Some Will Fly, And Others Won't. Retrieved from November 9, 2008 from http://wharton.universia.net/index.cfm?fa $=$ viewArticle\&id $=738 \&$ language $=$ english\&s pecialId $=82$.

Shamir, J., Reed, B. S. Connell, S. (1990). Individual differences in ethical values of public relations practitioners. Journalism Quarterly, 67, 956-963.

Sheehan, K. B., \& Hoy, M. G. (1999). Using e-mail to survey Internet users in the United States: Methodology and assessment. Journal of Computer Mediated Communication, 4 (3). 
Sloan, D. (1980). The teaching ethics in the American undergraduate curriculum, 1876-1976. In D. Callahan and S. Bok (Eds.), Ethics teaching in higher education, pp. 1-57. New York: Plenum Press.

South, J. (2004, August). Ethics in the classroom: Preparing journalism students for making tough decisions. Quill, 10-13.

Sparks, S. D., \& Conwell, P. (1998, Spring). Teaching public relations-does practice or theory prepare practitioners? Public Relations Quarterly, 41-44.

Stacks, D. W., Botan, C., \& VanSlyke Turk, J. (1999). Perceptions of public relations education. Public Relations Review, 25, 9-28.

Stacks, D. W., \& Wright, D. K. (1989). A quantitative examination of ethical dilemmas in public relations. Journal of Mass Media Ethics, 4, 53-67.

Surlin, S. H. (1987). Value system changes by students as result of media ethics course. Journalism Quarterly, 64, 564-676.

Tilley, E. (2005). The ethics pyramid: Making ethics unavoidable in the public relations process. Journal of Mass Media Ethics, 20, 305-320.

Toth, E. L. (1999). Models for instruction and curriculum. Public Relations Review, 25, 4553.

Trow, M. (1993). Comparative perspective on British and American higher education. In S. Rothblatt and B. Wittrock (Eds.), The European and American university since 1800. Historical and sociological essays, pp. 280-299. Cambridge, MA: Cambridge University Press.

Vercic, D., van Ruler, B., Butschi, G., \& Flodin, B. (2001). On the definition of public relations: A European view. Public Relations Review, 27, 373-387.

Wines, W. A. (2008). Seven pillars of business ethics: Toward a comprehensive framework. Journal of Business Ethics, 79, 483-499.

Worley, D. (2007). Relationship building in an Internet age. How organizations use web sites to communicate ethics, image, and social responsibility. In S. C. Duhe (Ed.), New media and public relations. New York: Peter Lang Publishing.

Wrench, J. S., Thomas-Maddox, C., Richmond, V. P., \& McCroskey, J. C. (2008). Quantitative research methods for communication. A hands-on approach. New York, NY: Oxford University Press.

Wright, D. K., \& Turk, J. V. (2007). Public relations knowledge and professionalism: Challenges to educators and practitioners. In E. L. Toth (Ed.), The future of 
excellence in public relations and communication management. Challenges for the next generation, pp. 571-588. Mahwah, NJ: Lawrence Erlbaum Associates.

Wright, D.K. (1985). Age and the moral values of practitioners. Public Relations Review, 11, 51-60.

Wueste, D. E. (1994). Introduction. In D. E. Wueste (Ed.), Professional ethics and social responsibility, pp. 1-35. Lanham, MD: Rowman \& Littlefield Publishers, Inc. 


\section{APPENDIX 1}

\section{SURVEY QUESTIONNAIRE}

UNIVERSITY TEACHERS’ PERCEPTIONS AND EVALUATIONS OF ETHICS

INSTRUCTION IN PUBLIC RELATIONS CURRICULUM

PART I

Section 1: Goals in teaching ethics

PLEASE INDICATE THE EXTENT TO WHICH YOU AGREE OR DISAGREE WITH EACH OF THE FOLLOWING STATEMENTS:

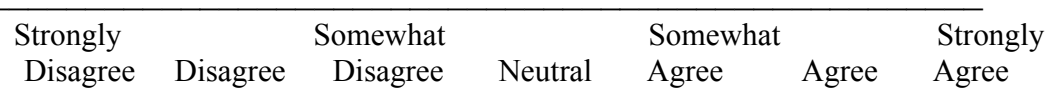

\section{A goal of ethics education is...}

1. ... to cultivate moral character.

12

3

4

5

6

7

2. ... to improve the moral cognitive capacities of PR students.

1

2

3

4

5

6

7

3. ... to familiarize students with ethical theories.

1

2

3

4

5

6

7

4. ... to develop socially responsible professionals.

1

2

3

4

5

6

7

5. ... to help students make good choices on the job.

1

2

3

4

5

6 7

Please list any other goal(s) that you believe is important: 
Section 2: Format of ethics instruction delivery and importance of ethics education

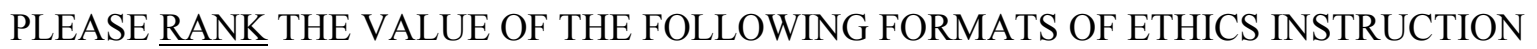
DELIVERY BY ENTERING A "1" IN THE SPACE AFTER THE MOST VALUABLE FORM OF DELIVERY, A "2" AFTER THE NEXT MOST VALUABLE FORM, AND A "3" AFTER THE LEAST VALUABLE :

1. Ethics instruction as a separate public relations ethics course:

2. Ethics instruction as a separate communication ethics course:

3. Ethics instruction incorporated in courses throughout the public relations curriculum:

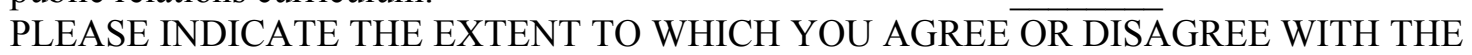
FOLLOWING STATEMENT:

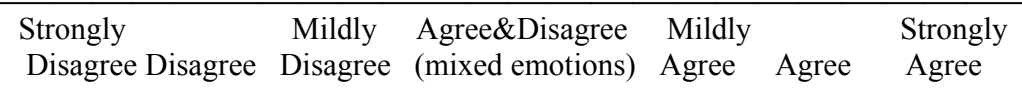

1. Ethics instruction in public relations education is essential.

1

2

3

4 5

6 7

Section 3: Pedagogies and resources in teaching ethics and tools for evaluating ethics learning

1. How effective have the following PEDAGOGIES IN TEACHING ethics been for you?

\begin{tabular}{|c|c|c|c|c|c|c|c|c|}
\hline & $\begin{array}{l}\text { Very } \\
\text { ineffective }\end{array}$ & Ineffective & $\begin{array}{l}\text { Somewhat } \\
\text { ineffective }\end{array}$ & $\begin{array}{l}\text { Neither ineffective } \\
\text { e nor effective }\end{array}$ & $\begin{array}{c}\text { Somewhat } \\
\text { effective }\end{array}$ & Effective & $\begin{array}{l}\text { Very } \\
\text { effective }\end{array}$ & $\begin{array}{l}\text { Haven't } \\
\text { used }\end{array}$ \\
\hline 1. Socratic dialogue & 1 & 2 & 3 & 4 & 5 & 6 & 7 & 9 \\
\hline 2. Guest presentations & 1 & 2 & 3 & 4 & 5 & 6 & 7 & 9 \\
\hline 3. Teacher lectures & 1 & 2 & 3 & 4 & 5 & 6 & 7 & 9 \\
\hline 4. Case studies & 1 & 2 & 3 & 4 & 5 & 6 & 7 & 9 \\
\hline 5. Group discussion & 1 & 2 & 3 & 4 & 5 & 6 & 7 & 9 \\
\hline $\begin{array}{l}\text { 6. Reading from trade and } \\
\text { professional publications }\end{array}$ & d & 2 & 3 & 4 & 5 & 6 & 7 & 9 \\
\hline 7. Student-led projects & 1 & 2 & 3 & 4 & 5 & 6 & 7 & 9 \\
\hline 8. Research papers & 1 & 2 & 3 & 4 & 5 & 6 & 7 & 9 \\
\hline
\end{tabular}


2. How effective have you found the following RESOURCES in teaching ethics to PR students?

\begin{tabular}{|c|c|c|c|c|c|c|c|c|}
\hline & $\begin{array}{l}\text { Very } \\
\text { ineffective }\end{array}$ & Ineffective & $\begin{array}{l}\text { Somewhat } \\
\text { ineffective }\end{array}$ & $\begin{array}{l}\text { Neither ineffective } \\
\text { e nor effective }\end{array}$ & $\begin{array}{l}\text { Somewhat } \\
\text { effective }\end{array}$ & Effective & $\begin{array}{l}\text { Very } \\
\text { effective }\end{array}$ & $\begin{array}{l}\text { Haven't } \\
\text { used }\end{array}$ \\
\hline 1. Textbook(s) & 1 & 2 & 3 & 4 & 5 & 6 & 7 & 9 \\
\hline $\begin{array}{l}\text { 2. Academic journal } \\
\text { articles }\end{array}$ & 1 & 2 & 3 & 4 & 5 & 6 & 7 & 9 \\
\hline $\begin{array}{l}\text { 3. Trade magazine } \\
\text { articles }\end{array}$ & 1 & 2 & 3 & 4 & 5 & 6 & 7 & 9 \\
\hline $\begin{array}{l}\text { 4. Newspaper or news- } \\
\text { magazine stories }\end{array}$ & 1 & 2 & 3 & 4 & 5 & 6 & 7 & 9 \\
\hline 5. Videos & 1 & 2 & 3 & 4 & 5 & 6 & 7 & 9 \\
\hline 6. Blogs & 1 & 2 & 3 & 4 & 5 & 6 & 7 & 9 \\
\hline $\begin{array}{l}\text { 7. Internet stories } \\
\text { or data bases }\end{array}$ & 1 & 2 & 3 & 4 & 5 & 6 & 7 & 9 \\
\hline
\end{tabular}

3. How effective have the following ASSESSMENT tools been for evaluating ethics learning in your PR classes?

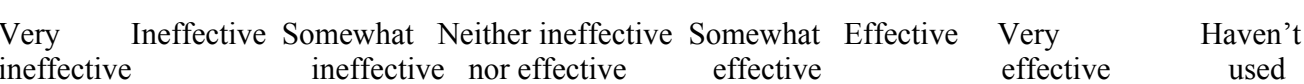

\begin{tabular}{lllllllll}
\hline 1. Written examinations & 1 & 2 & 3 & 4 & 5 & 6 & 7 & 9
\end{tabular}

$\begin{array}{lllllllll}\text { 2. Written case studies } & 1 & 2 & 3 & 4 & 5 & 6 & 7 & 9\end{array}$

3. Individual and panel presentations

$\begin{array}{lllllllll}\text { 4. Term papers } & 1 & 2 & 3 & 4 & 5 & 6 & 7 & 9 \\ \begin{array}{l}\text { 5. Group projects } \\ \text { 6. Individual projects }\end{array} & 1 & 2 & 3 & 4 & 5 & 6 & 7 & 9 \\ \begin{array}{l}\text { Please list any other assessment tools that have been effective for } \\ \text { you: }\end{array}\end{array}$


Section 4: Value to students of ethics education

PLEASE INDICATE THE EXTENT TO WHICH YOU AGREE OR DISAGREE WITH EACH OF THE FOLLOWING STATEMENTS:

\begin{tabular}{rcccc}
\hline & Strongly & Somewhat & Somewhat & Strongly \\
Disagree & Disagree & Disagree & Neutral Agree Agree Agree
\end{tabular}

1. Ethics education helps students become aware of ethical issues in PR.

1

23

4

$6 \quad 7$

2. Ethics education equips PR majors with the ability to make better moral judgments.

1

3. Ethics education helps students develop a sense of moral obligation.

12

3

4

$\begin{array}{lll}5 & 6 & 7\end{array}$

4. Ethics education helps students develop analytical skills.

$1-2$

3

\section{Ethics education inspires students to be moral} in their professional lives.

1

6. Ethics education teaches students to use moral reasoning to help resolve conflicts.

7. Ethics education helps students develop tools

for reasoning through ethical dilemmas.

8. Ethics education does NOT create moral character.

9. Ethics education arms PR students with ethical principles of persuasion.

12

10. Ethics education helps PR students realize that they have to be ethical to succeed. 1

11. Ethics education helps students develop strategic thinking skills.

1

12. Ethics education helps students maintain integrity in their professional lives.

12

3

$\begin{array}{llll}4 & 5 & 6 & 7\end{array}$

13. Ethics education helps students form an ethical frame of mind.

\section{1}

14. Ethics education he
their personal values.

1

2

1


Section 5: Ethics courses in the curriculum

PLEASE ANSWER THE FOLLOWING BY CIRCLING ALL THAT APPLY:

1. Does your department/college offer:

a. a specific course in PR ethics

b. a specific course in media/communication ethics

c. no specific courses in ethics

2. If your department/college DOES NOT have a free-standing course in ethics, what in your opinion is the reason:

1. Ethics is not as important as other elements of the profession

2. Ethics are lived, not learned

3. The curriculum can't include all important courses

4. Ethics is best taught throughout the curriculum, not just in one class

5. No one is qualified to teach an ethics course

6. other

\section{PART II}

PLEASE ANSWER THE FOLLOWING QUESTIONS ABOUT YOURSELF:

1. Gender:

a. Male

b. Female

2. Highest degree obtained:

a. Bachelors

b. Masters

c. Doctorate

d. Other

3. Highest degree in:

a. anthropology

b. business

c. communication studies

d. English

e. journalism

f. mass communication

g. philosophy

h. political science

i. public relations

j. sociology

k. other

\section{Academic rank:}

a. Instructor/lecturer

b. Assistant professor

c. Associate professor

d. Professor

e. Other 
5. Country of birth:

a. The US

b. Germany

c. Netherlands

d. South Korea

e. United Kingdom

f. Other (you may specify:

6. Country in which you currently teach:

a. The US

b. Germany

c. Netherlands

d. South Korea

e. United Kingdom

f. Other (please specify:

7. How many graduate level courses on average do you teach each year (12-month period)?

8. How many junior/seniors courses on average do you teach each year (12-month period)?

9. How many freshmen/sophomore courses on average do you teach (12-month period)?

10. How many years have you taught PR courses at the college or university level?

11. Have you ever taught a separate ethics course (PR ethics or communication/media ethics)?
a. yes
b. no

12. Did you complete an ethics course when you were a university student?

a. yes

b. no

13. Did you work as a PR practitioner?

a. yes

b. no

If your answer is "yes," please answer the following question:

14. How many years did you work as a PR practitioner?

15. Indicate all of the professional and academic organizations in which you a member:

a. Arthur W. Page Society

b. Association for Education in Journalism and Mass Communication

c. European Public Relations Education and Research Association

d. Institute for Public Relations

e. International Association of Business Communicators

f. International Communication Association

g. International Public Relation Association 
h. National Communication Association

i. Public Relations Society of America

j. other

\section{Thank you.}




\section{APPENDIX II \\ ELECTRONIC INVITATION TO PARTICIPATE IN SURVEY}

\section{First email}

Dear public relations teacher, My name is Elina Erzikova. I am a doctoral candidate in the College of Communication and Information Sciences. These days, I am working on my dissertation, Teaching Ethics to PR Majors. The purpose of this study is to examine the present state of teaching ethics in university public relations departments in the United States and in selected European countries. Your opinion is valuable to me and will help me better understand teaching perspective of those who educate future professionals. Your responses will be completely confidential and your participation is strictly voluntarily.

To access the survey, please visit following website:

[survey URL]

When you click on the above link, you will automatically be logged into the survey.

Thank you, Elina Erzikova

\section{Second email}

Dear public relations teacher,

Three weeks ago I started collecting data for my dissertation, Teaching Ethics to PR Majors. If you haven't participated in the web-based survey, please take a few minutes to complete it. Your responses will be completely confidential and your participation is strictly voluntarily. Your input is extremely valuable to this study because it will help analyze the current state of teaching ethics in public relations departments in the US and selected European countries.

To access the survey, please visit following website:

[survey URL]

When you click on the above link, you will automatically be logged into the survey.

Thank you, Elina Erzikova

\section{Third email}

Dear public relations teacher,

Two months ago I started collecting data for my dissertation, Teaching Ethics to PR Majors. If you haven't participated in the web-based survey, please take a few minutes to complete it. Your responses will be completely confidential and your participation is strictly voluntarily. Your input will be greatly appreciated. The website will be closed at midnight on July 7, 2008

To access the survey, please visit following website: 
[survey URL]

When you click on the above link, you will automatically be logged into the survey.

Thank you, Elina Erzikova 


\section{APPENDIX III \\ PARTICIPANT INFORMED CONSENT FORM FOR UNIVERSITY TEACHERS' PERCEPTIONS AND EVALUATIONS OF ETHICS INSTRUCTION IN PUBLIC RELATIONS CURRICULUM}

You are invited to participate in a research study conducted by Elina Erzikova, a doctoral student in the College of Communication and Information Science at the UNIVERSITY OF ALABAMA.

The purpose of this study is to explore perceptions of PR instructors toward teaching ethics in the undergraduate curriculum. Your opinion is valuable to me and will help me better understand teaching perspective of those who educate future professionals. You were selected as a possible participant in this study because you are a PR instructor.

If you decide to participate, you will be asked to complete a two-part questionnaire. It will take about 20 minutes to complete the questions.

Any information obtained in connection with this study and that can be identified with you will remain confidential and will be disclosed only with your permission or as required by law. To analyze the data, quantitative methods will be employed by me, Elina Erzikova. Subject identities will be kept confidential, and the files will be destroyed when the project is finished (or no later than three years from today's date). When reporting the results, no individuals will be identified.

This study is not being funded. This study is a dissertational research.

Your participation is voluntary. If you decide not to participate, you are free to withdraw your consent and discontinue participation at any time.

If you have any questions, please feel free to contact Elina Erzikova by phone 205.292.6819 or email erzik001@bama.ua.edu. If you have questions regarding your rights as a research subject, contact the Research Compliance officer at 205.348.5152. You can print a copy of this form to keep.

Completing the questionnaire constitutes your consent to participate in this study.

Thank you. 


\section{APPENDIX IV \\ INTERVIEW GUIDE WITH AMERICAN AND EUROPEAN PUBLIC RELATIONS INSTRUCTORS}

\section{Teaching Ethics to Public Relations Majors}

Thank you for agreeing to share your perspective about teaching ethics to public relations students. I would like you to ask a few questions that will help me understand your teaching philosophy and practice.

1. Do you think ethics education is essential for public relations students? Why?

2. What kind of approaches do you employ in your ethics classroom to insure students' effective learning?

3. What kind of resources and material do you find the most effective in the ethics classroom?

4. What are some ways to improve students' ethical capacity, or the ability to comprehend ethics issues?

5. How do you evaluate the effectiveness of your ethics instruction?

6. Do you believe that ethics education has a long-term effect on PR students?

On what kind of evidence your opinion is based?

7. In your opinion, what is the most important goal of ethics education?

8. In your opinion, what is an overall value to students of ethics education?

9. Based on your experience, what advice would you give to your colleagues regarding how to enhance ethics instruction at the university or college level? 
10. What do you think the American (British, Dutch, German) PR educational community should do to improve ethics education in the U.S.? 